

\section{Occurrence and Quality of Surface Water and Ground Water within the Yavapai-Prescott Indian Reservation, Central Arizona, 1994-98}

Water-Resources Investigations Report 00—4144

Prepared in cooperation with the

YAVAPAI-PRESCOTT INDIAN TRIBE 


\section{U.S. DEPARTMENT OF THE INTERIOR \\ BRUCE BABBITT, Secretary}

U.S. GEOLOGICAL SURVEY

Charles G. Groat, Director

The use of firm, trade, and brand names in this report is for identification purposes only and does not constitute endorsement by the U.S. Geological Survey.

For additional information write to:

District Chief

U.S. Geological Survey

Water Resources Division

520 N. Park Avenue, Suite 221

Tucson, AZ 85719-5035
Copies of this report can be purchased from:

U.S. Geological Survey

Information Services

Box 25286

Federal Center

Denver, C0 80225-0046

Information regarding research and data-collection programs of the U.S. Geological Survey is available on the Internet via the World Wide Web. You may connect to the home page for the Arizona District Office using the URL http://az.water.usgs.gov. 


\section{CONTENTS}

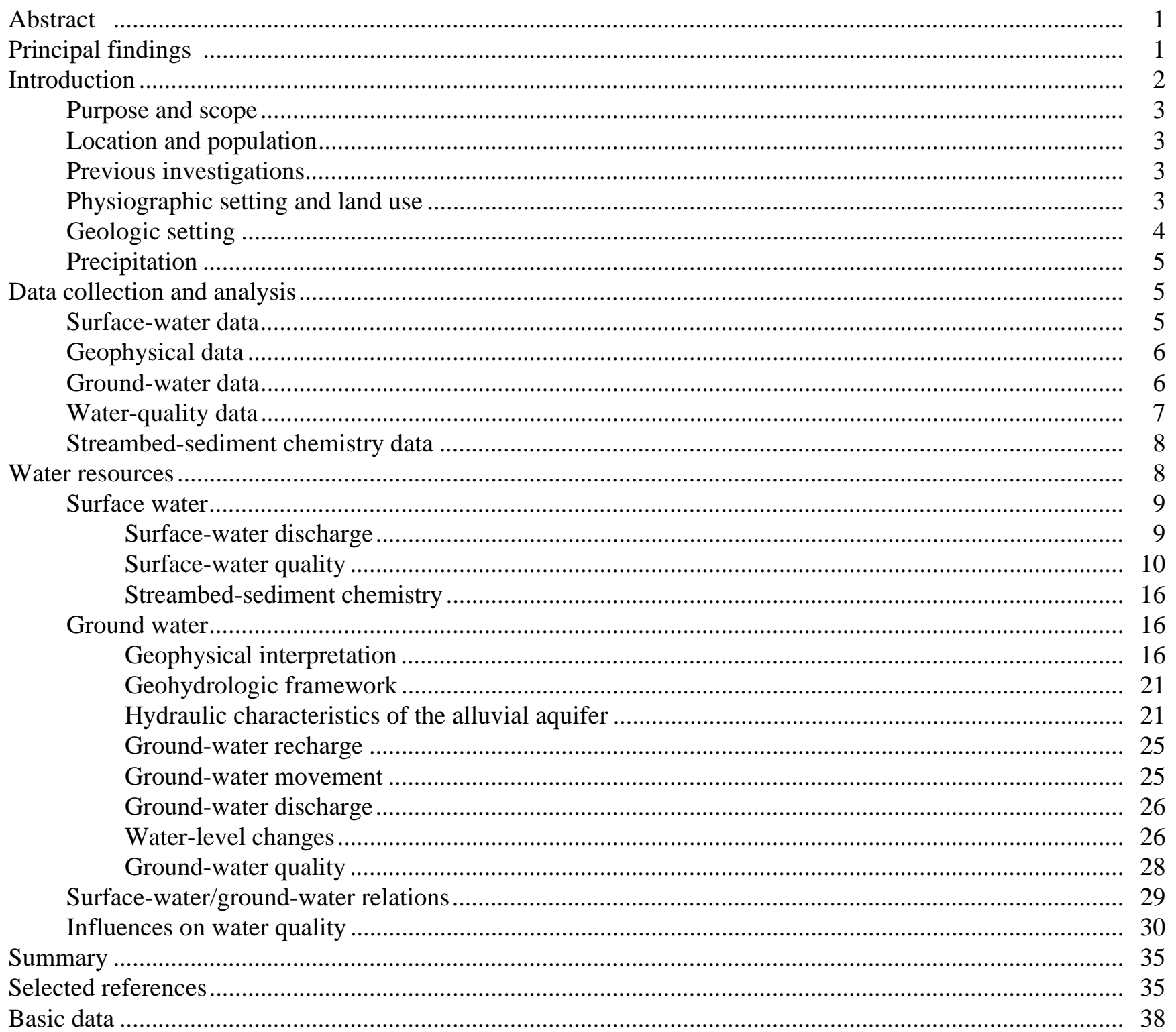




\section{FIGURES}

1-3. Maps showing:

1. Study area, Yavapai-Prescott Indian Reservation, Arizona

2. Generalized surficial geology of the Yavapai-Prescott Indian Reservation and geophysical survey lines along Granite Creek, Arizona

3. Data-collection sites, Yavapai-Prescott Indian Reservation, Arizona …...................................... 7

4-6. Plots showing:

4. Average monthly discharge and average monthly gain in streamflow, Granite Creek, Arizona, water years 1995-97.

A. Average monthly discharge at streamflow-gaging stations Granite Creek at

Prescott (09502960) and Granite Creek near Prescott (09503000), water years 1995-97....

B. Average monthly gain in streamflow in the reach of Granite Creek between streamflow-gaging stations Granite Creek at Prescott and Granite Creek near Prescott

5. Average monthly discharge at streamflow-gaging station, Granite Creek near Prescott, Arizona (09503000), water years 1933-41 and 1946 and 1995-97

6. Average monthly precipitation at Prescott, Arizona, water years 1933-41 and 1946 and 1995-97

7. Trilinear diagrams showing relative compositions of water on the Yavapai-Prescott

Indian Reservation, Arizona, 1994-98.

B. Ground water

C. Surface water and ground water

8-10. Plots showing:

8. Concentrations of calcium, chloride, and total dissolved solids in samples from Granite Creek at Prescott (09502960) and Granite Creek near Prescott (09503000), Arizona

9. Seismic depth profiles along Granite Creek, Yavapai-Prescott Indian Reservation, Arizona

10. Gamma logs and interpreted lithology for selected wells in the Granite Creek flood plain, Yavapai-Prescott Indian Reservation, Arizona

11. Map showing altitude of the water table, and hydrographs showing water levels at wells

YP-1 through YP-12, and daily precipitation, Yavapai-Prescott Indian

Reservation, Arizona.

A. Altitude of the water table, October 28, 1997

B. Water levels at wells YP-1 through YP-12 and daily precipitation, 1993-98.

12-13. Hydrographs showing:

12. Discharge at Granite Creek near Prescott (09503000), during periods of zero flow at Granite Creek at Prescott (09502960), Arizona, 1995-97

13. Water levels at wells YP-1 through YP-12, Yavapai-Prescott Indian Reservation, and stage of Granite Creek at streamflow-gaging station Granite Creek at Prescott (09502960), Arizona, 1994-98

14. Map showing general chemistry of surface water and ground water, Yavapai-Prescott Indian Reservation, Arizona, 1994-98.

15. Boxplots showing comparison of $\mathrm{pH}$ and selected constituent concentrations in surface-water and ground-water samples, Yavapai-Prescott Indian Reservation, Arizona, 1994-98. 


\section{TABLES}

1. Monthly average precipitation, Prescott, Arizona, 1899-97

2. Summary discharge data, Granite Creek at Prescott, Arizona (09502960), water years 1995-97

3. Summary discharge data, Granite Creek near Prescott, Arizona (09503000), water years 1995-97.

4. Statistical summary of spring discharge, Yavapai-Prescott Indian Reservation, Arizona, 1995-98

5. Statistical summary of surface-water discharge at streamflow-gaging station Granite Creek near Prescott (09503000), during periods of zero flow at streamflow-gaging station Granite Creek at Prescott (09502960), Arizona, 1995-97

6. Statistical summary of ground-water levels, Yavapai-Prescott Indian Reservation, Arizona, 1993-98

7. Data from crest-stage gages on tributaries of Granite Creek, Yavapai-Prescott Indian Reservation, Arizona, 1995-98

8. Discharge data, Granite Creek at Prescott (09502960), Arizona, water year 1995 .......................... 39

9. Discharge data, Granite Creek at Prescott (09502960), Arizona, water year 1996............................ 40

10. Discharge data, Granite Creek at Prescott (09502960), Arizona, water year 1997........................... 41

11. Discharge data, Granite Creek near Prescott (09503000), Arizona, water year 1995...................... 42

12. Discharge data, Granite Creek near Prescott (09503000), Arizona, water year 1996........................ 43

13. Discharge data, Granite Creek near Prescott (09503000), Arizona, water year 1997....................... 44

14. Field measurements and concentrations of selected inorganic constituents, nutrients, and bacteria in surface water from Granite Creek and Slaughterhouse Gulch,

Arizona, 1994-98

15. Concentrations of selected organic constituents in surface water from Granite Creek and Slaughterhouse Gulch, Arizona, 1994-98

16. Concentrations of selected inorganic and organic chemical constituents in streambed sediment from Granite Creek and Slaughterhouse Gulch, Arizona, 1994-98

17. Field measurements and concentrations of selected inorganic constituents, nutrients, and bacteria in water from wells and springs in the Granite Creek area, Yavapai-Prescott Indian Reservation, Arizona, 1994-98.

18. Concentrations of selected organic constituents in water from wells and springs in the Granite Creek area, Yavapai-Prescott Indian Reservation, Arizona, 1994-98 


\begin{tabular}{rll}
\hline Multiply & By & To obtain \\
\hline inch (in.) & 25.4 & millimeter \\
acre & 4,047 & square meter \\
foot $(\mathrm{ft})$ & 0.3048 & meter \\
square foot $\left(\mathrm{ft}^{2}\right)$ & 0.09290 & square meter \\
cubic foot $\left(\mathrm{ft}^{3}\right)$ & 0.02832 & cubic meter \\
foot per day $(\mathrm{ft} / \mathrm{d})$ & 0.3048 & meter per day \\
mile $\left(\mathrm{mi}^{2}\right)$ & 1.609 & kilometer \\
square mile $\left(\mathrm{mi}^{2}\right)$ & 2.590 & square kilometer \\
acre-foot $(\mathrm{acre}-\mathrm{ft})$ & 0.001233 & cubic hectometer \\
cubic yard $\left(\mathrm{yd}{ }^{3}\right)$ & 0.7646 & cubic meter \\
cubic foot per second $\left(\mathrm{ft}^{3} / \mathrm{s}\right)$ & 0.02832 & cubic meter per second \\
gallon per minute $\left(\mathrm{gal} / \mathrm{min}^{2}\right)$ & 0.06308 & liter per second \\
gallon per day per foot $(\mathrm{gal} / \mathrm{day} / \mathrm{ft})$ & 0.2670 & liter per second per meter \\
gallon $(\mathrm{gal})$ & 3.785 & liter \\
\hline
\end{tabular}

\section{ABBREVIATED WATER-QUALITY UNITS}

Chemical concentration and water temperature are given only in metric units. Chemical concentration in water is given in milligrams per liter $(\mathrm{mg} / \mathrm{L})$ or micrograms per liter $(\mu \mathrm{g} / \mathrm{L})$. Milligrams per liter is a unit expressing the solute mass (milligrams) per unit of volume (liter) of water. One thousand micrograms per liter is equivalent to 1 milligram per liter.

For concentrations less than 7,000 milligrams per liter, the numerical value is about the same as for concentrations in parts per million. Specific conductance is given in microsiemens per centimeter at 25 degrees Celsius $\left(\mu \mathrm{S} / \mathrm{cm}\right.$ at $\left.25^{\circ} \mathrm{C}\right)$. Chemical concentrations in streambed sediment are given in micrograms per gram $(\mu \mathrm{g} / \mathrm{g})$ or micrograms per kilogram $(\mu \mathrm{g} / \mathrm{kg})$. Micrograms per gram is equal to parts per million (ppm). Micrograms per kilograms is equal to parts per billion (ppb).

\section{VERTICAL DATUM}

Sea level: In this report, "sea level" refers to the National Geodetic Vertical Datum of 1929 (NGVD of 1929)—a geodetic datum derived from a general adjustment of the first-order level nets of the United States and Canada, formerly called "Sea Level Datum of 1929".

\section{DEFINITION OF SELECTED TERMS}

Terms related to streamflow, water-quality, and other hydrologic data as used in this report are defined below. Definitions from Smith and others. (1996).

Acre-foot-(AC-FT, acre-ft) is the quantity of water required to cover 1 acre to a depth of 1 foot and is equivalent to 43,560 cubic feet or about 326,000 gallons, or 1,233 cubic meters.

Aquifer - is a geologic formation, group of formations, or part of a formation that contains sufficient saturated permeable material to yield significant quantities of water to wells and springs. 
Bacteria —are microscopic unicellular organisms, typically spherical, rodlike, or spiral and threadlike in shape, often clumped into colonies, Some bacteria cause disease, while others perform an essential role in nature in the recycling of materials; for example, by decomposing organic matter into a form available for reuse by plants.

Cubic foot per second- $\left(\mathrm{ft}^{3} / \mathrm{s}\right)$ is the rate of discharge representing a volume of 1 cubic foot passing a given point during 1 second and is equivalent to approximately 7.48 gallons per second or 448.8 gallons per minute or 0.02832 cubic meters per second.

Discharge — is the volume of water (or more broadly, total fluid plus suspended sediment) that passes a given point within a given period of time.

Dissolved-refers to the material in a representative water samples which passes through a 0.45 -micrometer membrane filter. This is a convenient operational definition used by Federal agencies that collect water data. determinations of "dissolved" constituents are made on subsamples of the filtrate.

Dissolved-solids concentration — of water is determined either analytically or by the "residue-on-evaporation" method, or mathematically by totalling the dissolved concentrations of individual constituents reported in a comprehensive chemical analysis. During the analytical determination of dissolved solids, the bicarbonate (generally a major dissolved component of water) is converted to carbonate. Therefore, in the mathematical calculation of dissolved-solids concentration, the bicarbonate value, in milligrams per liter, is multiplied by 0.492 to reflect the conversion.

Drainage-area — of a stream at a specified location is that area, measured in a horizontal plane, enclosed by a topographic divide from which direct surface runoff from precipitation normally drains by gravity into the stream above the specified location.

Drive-point wells - are small-diameter, stainless-steel wells that are hand driven to the desired depth. In this study, wells were 1.5 inch in diameter and had a screened interval of 1.5 feet.

Fecal coliform bacteria - are bacteria that are present in the intestines or feces of warmblooded animals. There are often used as indicators of the sanitary quality of the water. In the laboratory they are defined as all organisms that produced blue colonies within 24 hours when incubated at $44.5^{\circ} \mathrm{C} \pm 0.2^{\circ} \mathrm{C}$ on $\mathrm{M}-\mathrm{FC}$ medium (nutrient medium for bacterial growth). Their concentrations are expressed as number of colonies per $100 \mathrm{~mL}$ of sample.

Fecal streptococcal bacteria - are bacteria found also in the intestines of warmblooded animals. Their presence in water is considered to verify fecal pollution. They are characterized as Gram-positive, cocci bacteria which are capable of growth in brain-heart infusion broth. In the laboratory they are defined as all the organisms which produce red or pink colonies within 48 hours at $35^{\circ} \mathrm{C} \pm 1.0^{\circ} \mathrm{C}$ on $\mathrm{KF}$-streptococcus medium (nutrient medium for bacterial growth). Their concentrations are expressed as numbers of colonies per $100 \mathrm{~mL}$ of sample.

Gaging station - is a particular site on a stream, canal, lake or reservoir where systematic observations of hydrologic data are obtained.

Hardness - of water is a physical-chemical characteristic that is commonly recognized by the increased quantity of soap that is required to produce lather. It is attributable to the presence of alkaline earths (principally calcium and magnesium) and is expressed as equivalent of calcium carbonate $\left(\mathrm{CaCo}_{3}\right)$.

Mean discharge - (Mean) is the arithmetic mean of individual daily mean discharges during a specific period.

Particle-size classification-used in this report agrees with the recommendation made by the American Geophysical Union Subcommittee on Sediment Terminology. The classification is as follows: 


\begin{tabular}{lcl}
\hline \multicolumn{1}{c}{ Classification } & Size, in millimeters & \multicolumn{1}{c}{ Method of analysis } \\
\hline Clay & $0.00024-0.004$ & Sedimentation \\
Silt & $.004-.062$ & Sedimentation \\
Sand & $.062-2.0$ & Sedimentation or sieve \\
Gravel & $2.0-64.0$ & Sieve \\
\hline
\end{tabular}

The particle-size distributions given in this report are not necessarily representative of all particles in transport in the stream. Most of the organic matter is removed and the sample is subjected to mechanical and chemical dispersion before analysis in distilled water. Chemical dispersion is not used for native-water analysis.

pH_ of water is the negative logarithm of the hydrogen-ion activity. solutions with pH less than 7 are termed "acidic" and solutions with a pH greater than 7 are termed "basic". Solutions with a pH of 7 are neutral. The presence and concentration of many dissolved chemical constituents found in water are, in part, influenced by the hydrogen-ion activity of water. Biological processes including growth, distribution of organisms, and toxicity of the water to organisms are also influenced. in part, by the hydrogen-ion activity of water.

Sediment - is solid material that originates mostly from disintegrated rocks and is transported by, suspended in, or deposited from water; it includes chemical and biochemical precipitates and decomposed organic material such as humus. The quantity, characteristics, and cause of the occurrence of sediment in streams are influenced by environmental factors. Some major factors are degree of slope, length of slope, soil characteristics, land usage, and quantity and intensity of precipitation.

Sodium-adsorption ratio-is the expression of relative activity of sodium ions in exchange reactions within soil and is an index of sodium or alkali hazard to the soil. Waters range in respect to sodium hazard from those which can be used for irrigation on almost all soils to those which are generally unsatisfactory for irrigation.

Specific conductance - is a measure of the ability of a water to conduct an electrical current. It is expressed in microsiemens per centimeter at $25^{\circ} \mathrm{C}$. Specific conductance is related to the type and concentration of ions in solutions and can be used for approximating the dissolved-solids content of the water. Commonly, the concentration of dissolved solids (in milligrams per liter) is about 65 percent of the specific conductance (in microsiemens). This relation is not constant from stream to stream, and it may vary in the same source with changes in the composition of the water.

Streamflow - is the discharge that occurs in a natural channel. Although the term "discharge" can be applied to the flow of a canal, the word "streamflow" uniquely describes the discharge in a surface stream course. The term "streamflow" is more general than "runoff" as streamflow may be applied to discharge whether or not it is affected by diversion or regulation.

Total-is the total amount of a given constituent in a representative water/suspended-sediment sample, regardless of the constituent's physical or chemical form. This term is used only when the analytical procedures assures measurement of at least 95 percent of the constituent present in both the dissolved and suspended phases of the sample. A knowledge of the expected form of the constituent in the sample, as well as the analytical methodology used, is required to judge when the results should be reported as "total". (Note that the word "total" indicates both that the samples consists of a water/suspended-sediment mixture and that the analytical method determined all of the constituent in the sample.)

Total, recoverable - is the amount of a given constituent that is in solution after a representative water/suspended sediment samples has been digested by a method (usually using a dilute acid solution) that results in dissolution of only readily soluble substances. Complete dissolution of all particulate matter is not achieved by the digestion treatment, and thus the determination represents something less than the "total" amount (that is, less than 95 percent) of the constituent present in the dissolved and suspended phases of the sample. To achieve comparability of analytical data, equivalent digestion procedures are required of all laboratories performing such analyses, because different digestion procedures are likely to produce different analytical results. 
Transmissivity —is the rate at which water is transmitted through a unit width of aquifer under a unit hydraulic gradient. The standard unit for transmissivity is cubic foot per day per square foot times foot of aquifer thickness $\left[\left(\mathrm{ft}^{3} / \mathrm{d}\right) / \mathrm{ft}^{2}\right] \mathrm{ft}$. In this report, the mathematically reduced form, foot squared per day $\left(\mathrm{ft}^{2} / \mathrm{d}\right)$, is used for convenience.

Water year-in U.S. Geological Survey reports dealing with surface-water supply is the 12-month period, October 1 through September 30. the water year is designated by the calendar year in which it ends and which includes 9 of the 12 months. Thus, the year ending September 30, 1996, is called the "1996 water year".

Weighted average - is used in this report to indicate grain-size weighted average. It is computed by multiplying the total mass of material for a given sampling depth by the concentration of individual grain-size distributions for the corresponding depth and dividing the sum of the products by the sum of the masses. In this case, a grain-size weighted average approximates the composition of alluvial material that would be found at a given location, to a given depth after thorough mixing. 


\title{
Occurrence and Quality of Surface Water and Ground Water within the Yavapai-Prescott Indian Reservation, Central Arizona, 1994-98
}

\author{
By G.R. Littin, Margot Truini, H.A. Pierce, and B.M. Baum
}

\begin{abstract}
The Yavapai-Prescott Indian Reservation encompasses about 1,395 acres in central Arizona adjacent to the city of Prescott. From October 1994 to September 1997, the annual average rainfall was 14.9 inches and the total annual streamflow leaving the reservation along Granite Creek was about 430 acre-feet more than the amount of streamflow entering the reservation. The channel-fill and valley-fill sediments within the flood plain of Granite Creek make up the principal aquifer. The only ground-water development is from spring discharge that is being contained for livestock and wildlife use. About 29 acre-feet of ground water leaves the reservation each year after discharging into Granite Creek. Water levels in wells throughout the reservation reflect seasonal variations in rainfall and snowmelt.

Surface water and ground water on the reservation are calcium bicarbonate types. Specificconductance field measurements ranged from 187 to 724 microsiemens per centimeter for surface water and 381 to 990 microsiemens per centimeter for ground water. Fecal streptococcal bacteria and fecal coliform bacteria in the surface water make the water unsuitable for domestic use. Some volatile and semivolatile organic compounds were detected in samples of surface water, ground water, and streambed sediment. The potential for contamination exists from point and nonpoint sources on and off the reservation.
\end{abstract}

\section{PRINCIPAL FINDINGS}

1. The total annual streamflow leaving the reservation along Granite Creek during water years 1995-97 was about 430 acre-ft more than the amount of streamflow entering the reservation. About 29 acre-ft of that amount is contributed by ground-water discharge from the alluvium.

2. Fecal streptococcal and fecal coliform bacteria were detected in Granite Creek and make the surface water unsuitable for use by humans.

3. The channel-fill and valley-fill sediments along the flood plain of Granite Creek make up the principal aquifer. The estimated total storage potential for the aquifer west of U.S. Highway 89 is $3.52 \times 10^{8} \mathrm{ft}^{3}(8,080$ acre- $\mathrm{ft})$ and the estimated effective storage is about $1.64 \times 10^{8}$ $\mathrm{ft}^{3}$ (3,760 acre-ft).

4. Annual discharge from two springs was about 9.5 acre-ft.
5. Ground water in the channel-fill sediments generally moves in the same direction as surface-water flow (southwest to northeast). Rate of ground-water movement was estimated at about $0.04 \mathrm{ft} / \mathrm{d}$.

6. Water levels respond to seasonal variations in rainfall and snowmelt.

7. Trilinear analysis of the major chemical ions in surface-water and ground-water samples indicate that surface water and ground water are calcium bicarbonate types.

8. Some volatile and semivolatile organic compounds were detected in surface-water, sediment, and ground-water samples.

9. On the basis of studies at a wood-treatment site in Pensacola, Florida, and an estimated groundwater flow rate of $0.04 \mathrm{ft} / \mathrm{d}$ in this study, natural restoration of the aquifer in the Slaughterhouse Gulch area may take as long as 200 years. 


\section{INTRODUCTION}

The Yavapai-Prescott Indian Reservation includes an area of about 1,395 acres (about $2 \mathrm{mi}^{2}$ ) and is surrounded on the south, west, and north by the city of Prescott, Arizona (fig. 1). Granite Creek, which roughly bisects the reservation, flows intermittently and drains an area of about $30 \mathrm{mi}^{2}$ to the south and west of the reservation, including the city of Prescott.

Surface water in the creek is used only to support livestock and wildlife. Alluvial deposits along Granite Creek make up the principal aquifer on the reservation. Ground water is stored within the voids of these deposits and in variable amounts in fractured and decomposed igneous rocks of Precambrian age that underlie the alluvial deposits and are exposed in various parts of the reservation.

The Yavapai-Prescott Indian Tribe obtained water rights through the Yavapai-Prescott Indian Water Resources Settlement Act of 1994 (U.S. House of Representatives, 1994). This act provides the tribe with priority to the first 550 acre-feet of production by the city of Prescott Water Division, even in times of extreme shortage. This amount is ample to meet the tribe's current needs and projected growth on the reservation.

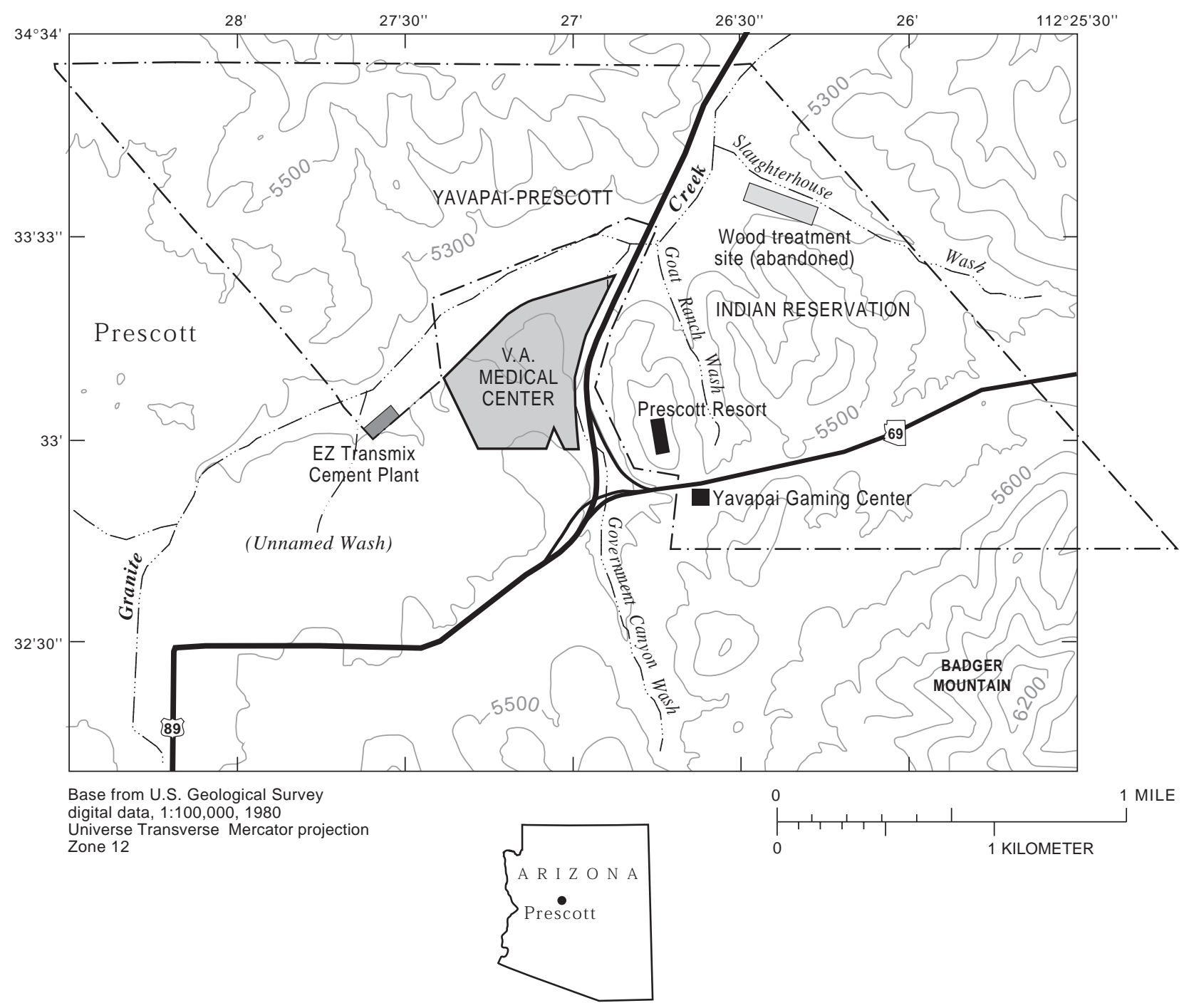

Figure 1. Study area, Yavapai-Prescott Indian Reservation, Arizona. 
As with many tribes in the southwestern United States, the primary water-resource concerns of the Yavapai-Prescott Indian Tribe are related to water rights, availability, and quality. In 1993, the tribe invited the U.S. Geological Survey (USGS) to investigate the water-resources on the reservation and identify sources of potential point and nonpoint contamination of Granite Creek and the underlying alluvial aquifer. Preliminary field work began in the summer of 1993 when water levels were measured in two monitor wells.

\section{Purpose and Scope}

The purpose of this report is to describe the occurrence and quality of surface water and ground water on the Yavapai-Prescott Indian Reservation from September 1994 to September 1998. The scope includes the presentation and analysis of data including continuous and periodic measurements of surfacewater flow (October 1994 to September 1998) and depth to ground water (August 1993 to June 1998); water quality (September 1994 to September 1998); and aquifer composition, thicknesses, and hydraulic properties. Surface-water data include discharge measurements from two continuous-record streamflow-gaging stations, periodic stage measurements from four tributaries, and water-quality analysis of samples collected during base-flow and storm-runoff conditions. Ground-water data include quarterly water-level measurements from 12 monitor wells, discharge measurements from 2 springs, and water-quality data from 9 wells and 2 springs. Aquifer data include lithologic and natural-gamma logs from boreholes, surface-geophysical profiles, and the results of two water-level recovery tests.

\section{Location and Population}

The Yavapai-Prescott Indian Reservation (fig. 1) was established by an act of Congress for the YavapaiPrescott Tribe in 1935 (U.S. House of Representatives, 1935). The reservation includes about 1,395 acres and is along the northeast corporate boundary of the city of Prescott. Originally established on 75 acres of the old Fort Whipple Military Reserve, the reservation was expanded to 1,395 acres in 1956.

The current population on the reservation is about 250; about 149 are tribal members. Almost all the population is in the western part of the reservation, and there is no individual ownership of tribal lands.

\section{Previous Investigations}

Consulting firms and the University of Arizona have studied hydrology on or near the reservation. These studies have included geologic mapping of the area in and near Prescott, compilations of records of springs and wells, aquifer and pump tests, seismicrefraction surveys, ground-water and surface-water sampling, flood-plain delineation and step-backwater surveys of Granite Creek, photogrammetric and field surveys of existing and potential water supplies, collection and compilation of drillers' logs, and a review of previous ground-water contamination studies.

Krieger (1965) studied the geology of the Prescott and Paulden 15-minute quadrangle areas and presented a geologic description and maps as well as an inventory of springs and wells. The USGS measured streamflow in Granite Creek from 1932-47 and published the discharge data (U.S. Geological Survey, 1954).

\section{Physiographic Setting and Land Use}

The Mexican Highland physiographic province of central Arizona (Fenneman, 1931) is on hilly terrain composed of weathered granitic rock and semiconsolidated sedimentary deposits. The reservation ranges in altitude from about 5,200 ft along Granite Creek where the creek exits the northeast boundary of the reservation to about $5,900 \mathrm{ft}$ at the western boundary near the summit of Badger Mountain.

Vegetation consists of pine, juniper, oak, and other associated plants typical of the Mexican Highland physiographic province of Arizona. The reservation has thin to moderate coverage of high chaparral grasses and other endemic plant assemblages which, in general, can be classified as light vegetation coverage. Light to moderate stands of cottonwood and sycamore trees and other vegetation typical of a riparian environment occur in places along Granite Creek.

Historically, the Yavapai-Prescott Tribe has maintained a society based on hunting, gathering, and farming. In recent years, the economic base of the tribe has shifted to retail commerce, gaming, and livestock. Commercial enterprises include a resort hotel, casinos, and a shopping center along State Highway 69 near the southern boundary of the reservation (fig. 1). A few small industries are along Granite Creek at the western and eastern boundaries. Recreation and wildlife are becoming more important to the tribe as the tribe expands its resources and interests in these areas. 


\section{Geologic Setting}

Lithologic units within the reservation include igneous rocks of Precambrian age, fluvial deposits and volcanic rocks of Tertiary to Quaternary age, and recent alluvial sediments (fig. 2; Krieger, 1965).

The Precambrian igneous rocks are exposed in the western, southeastern, and north-central parts of the reservation and include the Prescott Granite, Government Canyon Granodiorite, and less prominent exposures of gabbro and basaltic rocks. Tertiary fluvial deposits, also referred to as valley fill in the ChinoPrescott Valley area (Krieger, 1965) and in this report, overlie the Precambrian igneous rocks and contain varied amounts of poorly sorted, weekly to strongly cemented clay, silt, sand, and gravels of locally derived granitic and volcanic rocks (Krieger, 1965). The valley fill accounts for about 40 percent of the rocks exposed on the reservation and forms an erosional surface over which recent alluvial sediments have been deposited. Erosional features such as buried channels may underlie present-day tributaries along Granite Creek. Recent alluvial sediments, referred to as channel fill in this report, are exposed along Granite Creek and its tributaries and cover about 10 percent of the reservation. These sediments are composed of unconsolidated, unsorted, poorly bedded clay, silt, fineto coarse-grained sand, pebbles, cobbles, and scattered, generally well-rounded boulders.

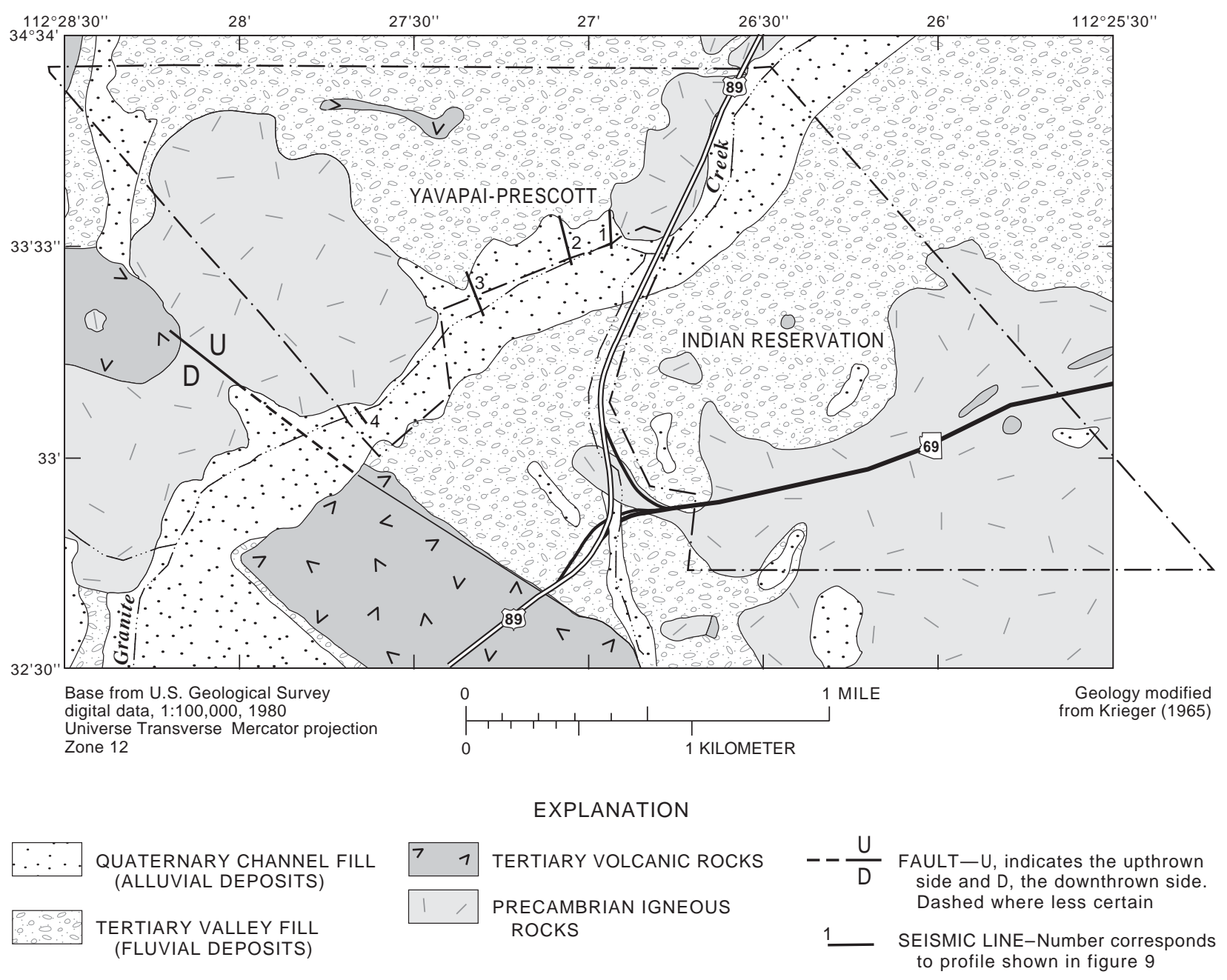

Figure 2. Generalized surficial geology of the Yavapai-Prescott Indian Reservation and geophysical survey lines along Granite Creek, Arizona. 


\section{Precipitation}

The climate throughout the reservation is arid to semiarid and temperatures are generally mild year round. Average daily high temperatures vary from the mid-80s $\left({ }^{\circ} \mathrm{F}\right)$ during the summer months to the mid-30s during the winter. Precipitation averages about $19.5 \mathrm{in} . / \mathrm{yr}$ on the basis of historical records (Sellers and others, 1985; National Oceanographic and Atmospheric Administration, 1933-97). On the basis of data from October 1994 to September 1997, the average annual precipitation at Prescott was 14.9 in. (table 1).

\section{DATA COLLECTION AND ANALYSIS}

For the purposes of this report, data collection is divided into surface-water, geophysical, ground-water, and water-quality activities. The following sections describe where and how data were collected and analyzed during the investigation.

\section{Surface-Water Data}

Data were collected at two continuous-record streamflow-gaging stations installed in 1994 along Granite Creek-one at the upstream (west) boundary of the reservation (Granite Creek at Prescott, 09502960) and the other at the bridge on Sundog Ranch Road near the downstream (east) boundary (Granite Creek near Prescott, 09503000). Crest-stage data were collected near the confluence of each of the four main tributaries along the south flank of Granite Creek - an unnamed wash, Government Canyon Wash, Goat Ranch Wash, and Slaughterhouse Gulch.

Surface-water data were collected using procedures outlined in Benson and Dalrymple (1967), Buchanan and Somers $(1968,1969)$, and Rantz and others (1982a and b). Discharge data from the continuous-record streamflow-gaging stations on Granite Creek are published by the USGS each year in the annual hydrologic-data report series for Arizona.

Table 1. Monthly average precipitation, Prescott, Arizona, 1899-97

[Data are missing for some months of some years]

\begin{tabular}{|c|c|c|c|c|}
\hline \multirow[b]{2}{*}{ Month } & \multicolumn{2}{|c|}{ Water years 1899-94 } & \multicolumn{2}{|c|}{ Water years 1995-97 } \\
\hline & $\begin{array}{l}\text { Monthly average, } \\
\text { in inches }\end{array}$ & $\begin{array}{c}\text { Percent of annual } \\
\text { average precipitation }\end{array}$ & $\begin{array}{l}\text { Monthly average, } \\
\text { in inches }\end{array}$ & $\begin{array}{c}\text { Percent of annual } \\
\text { average precipitation }\end{array}$ \\
\hline October & 1.10 & 5.6 & 0.45 & 3.0 \\
\hline November & 1.33 & 6.8 & .61 & 4.1 \\
\hline December & 1.73 & 8.9 & .92 & 6.2 \\
\hline January & 1.79 & 9.2 & 2.30 & 15.4 \\
\hline February & 1.92 & 9.8 & 1.85 & 12.4 \\
\hline March & 1.79 & 9.2 & 1.05 & 7.1 \\
\hline April & .93 & 4.8 & .63 & 4.3 \\
\hline May & .51 & 2.6 & .31 & 2.1 \\
\hline June & .39 & 2.0 & .20 & 1.4 \\
\hline July & 2.95 & 15.2 & 1.74 & 11.7 \\
\hline August & 3.36 & 17.2 & 1.65 & 11.1 \\
\hline September & 1.70 & 8.7 & 3.14 & 21.2 \\
\hline Annual & 19.49 & 100 & 14.9 & 100 \\
\hline
\end{tabular}




\section{Geophysical Data}

Surface and borehole geophysical data were collected to help determine hydrologic properties and define the geometry of the Granite Creek ground-water system within the Yavapai-Prescott Indian Reservation. Data were collected in accordance with procedures outlined in Haeni (1988) and Keys (1990). Low-energy seismic refraction was used to measure depths to competent signal refractors such as the surface of the Precambrian igneous rocks underlying the valley fill along Granite Creek. Geophones laid out in a line ahead of the energy source received the refracted energy that was then recorded for postprocessing of signal velocities as a function of depth to refracting materials. By measuring the travel time of the sound wave and applying the laws of physics that govern the propagation of sound in elastic media, the subsurface geology was inferred. Most geophysical measurements were made using System International (SI) units and were converted to English units for this report. Original measurements are shown in parentheses following the converted measurements.

Interpretations based on intercept times and crossover distance-depth formulas were based on the following assumptions: (1) the boundaries between lithologic layers are planes that are either horizontal or dipping at a constant angle, (2) each layer is homogeneous and isotropic, and (3) the seismic velocity of the layers increases with depth. Another important assumption is that there is no land-surface relief along the lines. In this study, all geophones and shotpoints were surveyed using a total station instrument and fieldelevation corrections were made before processing.

Four roughly north-south seismic lines were surveyed in July 1998 across Granite Creek (fig. 2). The lines were run normal to the creek and between U.S. Highway 89 and the southwestern boundary of the reservation. The first and easternmost line was about $500 \mathrm{ft}$ west of the intersection of Granite Creek and the U.S. Highway 89 bridge. The second line was about $1,500 \mathrm{ft}$ west of the bridge. The third line was $1,500 \mathrm{ft}$ west of line 2 and in line with monitor wells YP-9 and YP-10 (figs. 2 and 3). The fourth and westernmost line was along the western boundary of the reservation. Plots of data from all lines are oriented north-to-south, that is, north on the left of the plot and south on the right. Distance between geophones was $26.2 \mathrm{ft}(8 \mathrm{~m})$ for lines 1, 2, and 3, and $13.1 \mathrm{ft} \mathrm{(4} \mathrm{m)} \mathrm{for} \mathrm{line} \mathrm{4.} \mathrm{Each}$ line contained 24 geophones. Lines 1, 2, and 3, therefore, were $603.7 \mathrm{ft}$ (184 m) long, and line 4 was half that distance or $301.8 \mathrm{ft}(92 \mathrm{~m})$ long.

Borehole data were collected using natural-gamma sensing equipment. This method provides a record of the gamma radiation detected in a well borehole from the natural-gamma emitting characteristics of the rock and is a function of (1) the rock density, (2) the amount of energy being radiated, and (3) the type of probe used. In general, shaley or clay-bearing materials are higher gamma-emitting sources than coarse-grained material. This method was used to help delineate the contact between the channel fill and valley fill in monitor wells.

\section{Ground-Water Data}

Ground-water data were collected from a network of 12 observation wells, 2 drive-point wells, and 2 springs that generally were in areas underlain by channel fill. Data were obtained from water-level measurements, monitor-well drilling and development, and well-recovery tests. Discharge data were collected at a spring in the Goat Ranch Wash drainage and at a spring in the Slaughterhouse Gulch drainage using a 3-inch Parshall flume. Because of channel geometry, streambed composition, and other conditions at the point of measurement, some flow passed under or around the flume during a given measurement. Ground-water data were collected from a network of 12 observation wells, 2 drive-point wells, and 2 springs that generally were in areas underlain by channel fill. Data were obtained from water-level measurements, monitor-well drilling and development, and wellrecovery tests. Discharge data were collected at a spring in the Goat Ranch Wash drainage and at a spring in the Slaughterhouse Gulch drainage using a 3-inch Parshall flume. Because of channel geometry, streambed composition, and other conditions at the point of measurement, some flow passed under or around the flume during a given measurement. Groundwater data were collected using procedures outlined in Shuter and Teasdale (1989), Stallman (1971), Koterba and others (1995), and Lapham and others (1995). 


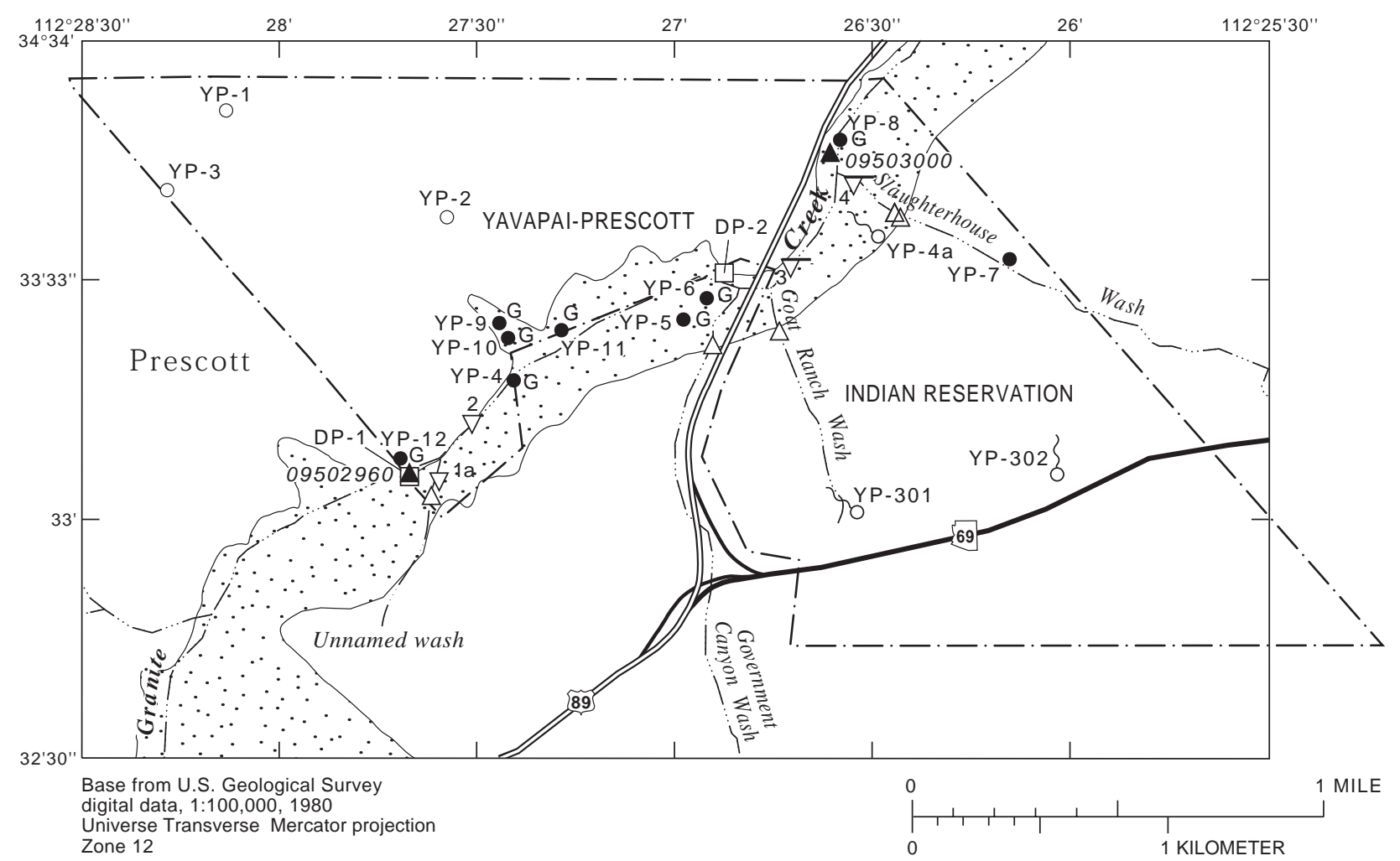

EXPLANATION
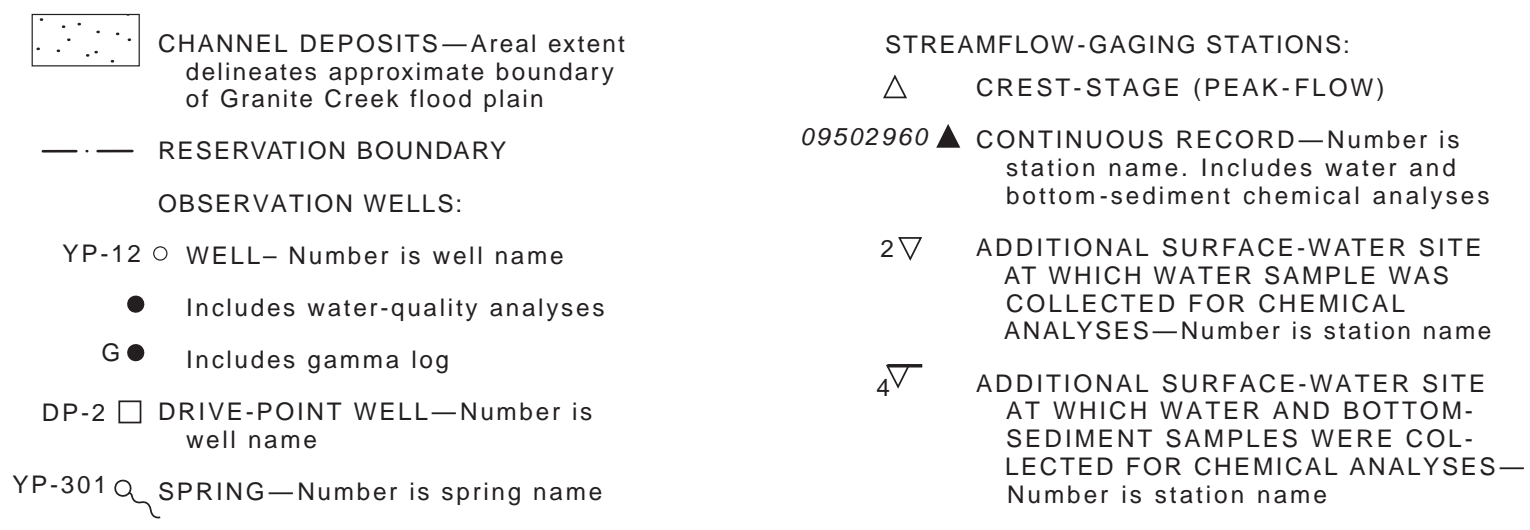

Figure 3. Data-collection sites, Yavapai-Prescott Indian Reservation, Arizona.

\section{Water-Quality Data}

Sampling sites were selected on the basis of a reconnaissance of the area and the location of potential point and nonpoint sources of contaminants. Potential point-source contributors of contaminants include the landfill at the VA Medical Center, the abandoned Stone Container wood-treatment site, the EZ Transmix cement plant, and the Yavapai Gaming Center (from pre-existing underground storage tanks; fig. 1).
Potential nonpoint sources of contaminants include sediment load from erosion, storm runoff from the city of Prescott, and livestock grazing along Granite Creek.

Surface-water samples were collected at the two continuous-record streamflow-gaging stations on Granite Creek, at the downstream exit of a culvert at the west boundary of the reservation (site 1a) about $100 \mathrm{ft}$ east of the gaging station Granite Creek at Prescott, at two additional sites along Granite Creek (sites 2 and 3), and at one site on Slaughterhouse Gulch 
(site 4 , fig. 3 ). Site 2 is about 0.4 mi downstream from the gaging station Granite Creek at Prescott. Site 3 is immediately downstream from the mouth of Goat Ranch Wash. Site 4 is on Slaughterhouse Gulch about $100 \mathrm{ft}$ upstream from the mouth.

At surface-water sites, temperature and dissolved oxygen were measured in the stream along a cross section to ensure a representative average. Specific conductance, $\mathrm{pH}$, and alkalinity were measured using a representative sample of water from a cross section across the stream as outlined in Shelton (1994). Surface-water samples were analyzed for major ions, trace metals, nutrients, volatile organic compounds (VOCs), semivolatile organic compounds (SVOCs), and bacteria.

Ground-water samples were collected once from wells YP-4 through YP-7, YP-11, drive-point wells DP-1 and DP-2, and springs YP-301 and YP-4a. Samples were collected twice from wells YP-8, YP-9, YP-10, and YP-12, and spring YP-301. Well DP-1 was in the middle of Granite Creek near the upstream gaging station (Granite Creek at Prescott), and well DP-2 was on the bank close to the edge of Granite Creek upstream from Government Canyon Wash (fig. 3). Specific conductance, $\mathrm{pH}$, dissolved oxygen, and water temperature were monitored during well purging until stable readings were obtained to ensure that ground-water samples were representative of the aquifer. Ground-water samples were analyzed for major ions, trace metals, nutrients, and VOCs.

Surface-water and ground-water samples were filtered using a 0.45 -micrometer filter for analyses of selected major ions, trace metals, and nutrients. Sulfuric acid was used on site to acidify samples to a $\mathrm{pH}$ of less than 2 and preserve them for analyses of selected major ions and trace metals. Raw, unfiltered samples were collected for the analyses of VOCs, SVOCs (including pesticides), and selected major ions and nutrients. All water samples were analyzed by the USGS National Water-Quality Laboratory in Arvada, Colorado. Fishman and Friedman (1989) discuss analytical methods used for samples analyzed by the National Water-Quality Laboratory. Dissolved concentrations of some trace metals were in some cases higher than the total or total-recoverable concentrations in laboratory analyses. The differences probably resulted from differences in precision between the analytical techniques used. The dissolved fraction was analyzed using inductively coupled plasma-emission spectroscopy (ICP); the total or total-recoverable concentration was analyzed using a graphite furnaceequipped atomic absorption (GFAA) spectrophotometer, which is less precise. Discrepancies also can result from rounding of values. Total and totalrecoverable concentrations, therefore, are considered to be at least equal to dissolved concentrations.

Where appropriate, constituent concentrations from water samples were compared to the U.S. Environmental Protection Agency's (USEPA) Maximum Contaminant Levels (MCLs) and Secondary Maximum Contaminant Levels (SMCLs) for drinking water. The MCLs are the maximum permissible level of a contaminant in water that is delivered to any user of a public water system; the SMCLs are unenforceable Federal guidelines regarding taste, odor, color, and certain other aesthetic effects of drinking water (U.S. Environmental Protection Agency, accessed May 19, 1999). Bacteria analyses were compared to State of Arizona surface-water quality standards.

\section{Streambed-Sediment Chemistry Data}

Streambed-sediment samples were collected at the two continuous-record streamflow-gaging stations and at sites 3 and 4 (fig. 3 and table 16 in the "Basic Data" section of this report). Samples for trace-element and VOC analyses were collected using the procedures established by Shelton and Capel (1994).

\section{WATER RESOURCES}

The water resources of the Yavapai-Prescott Indian Reservation consist of perennial streamflow in Granite Creek, ground water in the channel fill and valley fill along Granite Creek and its tributaries, ground water in joints and fractures within the Precambrian igneous rocks, and spring discharge. The surface-water flow in Granite Creek is maintained primarily by direct runoff of precipitation and by ground-water discharge on and off the reservation. Surface-water flow is currently used to maintain livestock and wildlife. Two prominent springs discharge from fractured granite near the reservation's south boundary. 


\section{Surface Water}

The reservation is drained by Granite Creek and its tributaries (fig. 1). The main tributaries are an unnamed wash at the southwest boundary of the reservation, Government Canyon Wash, Goat Ranch Wash, and Slaughterhouse Gulch. These tributaries drain the area of the reservation south of Granite Creek and parts of the city of Prescott and Prescott National Forest. Minor tributaries drain the area north of Granite Creek. Parts of Granite Creek, Goat Ranch Wash, and

Slaughterhouse Gulch are perennial where springs contribute flow. Elsewhere, the tributaries are dry except during periods of intense or prolonged rainfall or spring snowmelt. Bank storage provides water to the streams for several weeks and longer following periods of prolonged rainfall or snowmelt. Granite Creek drains about 60 percent of the city of Prescott before entering the reservation. Granite Creek is a gaining stream throughout much of the reservation. During the spring and summer months, ground-water levels near the creek decline to below the level of the streambed as a result of evapotranspiration.

Some of the storm runoff in ephemeral channels is captured by small stock ponds throughout the reservation and is used to support livestock and wildlife. None of the surface-water resources are used for drinking-water supplies.

\section{Surface-Water Discharge}

Discharge data for Granite Creek were collected at the streamflow-gaging station Granite Creek at Prescott (09502960) at the west boundary of the reservation off EZ Street and the streamflow-gaging station Granite Creek near Prescott (09503000) at Sundog Ranch Road (fig.3; tables 2 and 3). Daily discharge records for these stations are listed in tables 8-13 in the "Basic Data" section at the end of the report.

Table 2. Summary discharge data, Granite Creek at Prescott, Arizona (09502960), water years 1995-97

[Values for mean, maximum, and minimum are in cubic feet per second]

\begin{tabular}{|c|c|c|c|c|c|c|c|c|c|c|c|c|}
\hline \multicolumn{13}{|c|}{ Discharge, in cubic feet per second, water years 1995 through 1997} \\
\hline & Oct. 1 & Nov. 1 & Dec. & Jan. & Feb. & Mar. & Apr. & May & Jun. & Jul. & Aug. & Sep. \\
\hline Mean & .10 & .18 & .68 & 11.9 & 29.4 & 27.3 & 2.85 & .66 & .08 & 2.04 & .76 & 7.61 \\
\hline Maximum & .91 & 4.6 & 11 & 201 & 918 & 940 & 16 & 8.5 & .46 & 39 & 10 & 314 \\
\hline Minimum & .03 & .05 & .07 & .10 & .10 & .50 & .08 & .00 & .00 & .00 & .00 & .00 \\
\hline Acre-feet & $12+$ & $22+$ & 126 & 2,190 & 4,950 & 5,040 & 509 & 121 & 15 & 377 & 140 & 1,360 \\
\hline \multicolumn{5}{|c|}{ Water year 1995-97 } & Mean 6 & & Maximum & 940 & Minimum & 0.00 & Acre-feet & 14,900 \\
\hline
\end{tabular}

Table 3. Summary discharge data, Granite Creek near Prescott, Arizona (09503000), water years 1995-97

[Values for mean, maximum, and minimum are in cubic feet per second]

Discharge, in cubic feet per second, water years 1995 through 1997

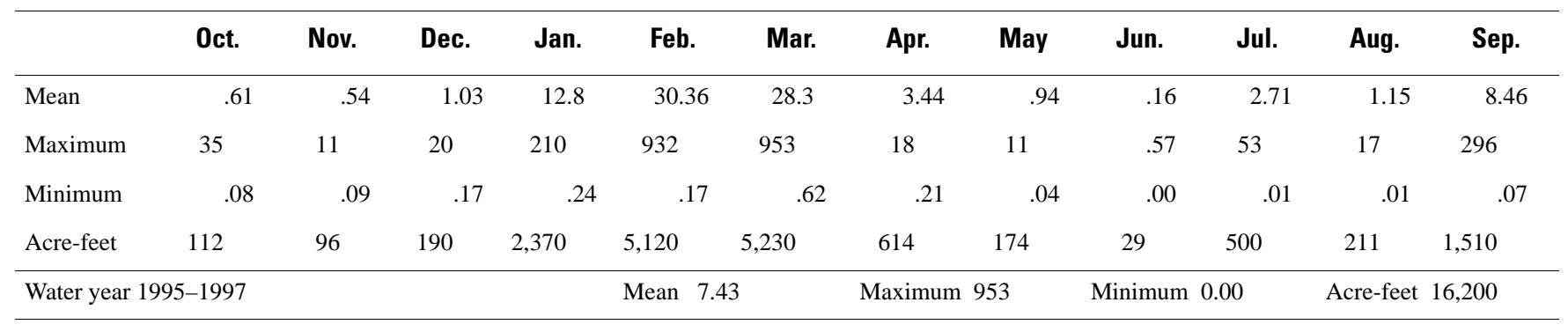


Granite Creek drains an area of about $30 \mathrm{mi}^{2}$ before entering the Yavapai-Prescott Indian Reservation at the upstream gaging station (09502960). The average annual volume of streamflow that passed this station during water years 1995 through 1997 was about 4,970 acre-ft. The downstream gaging station (09503000) monitors discharge from an additional $6.3 \mathrm{mi}^{2}$ area, $2.1 \mathrm{mi}^{2}$ of which is within the reservation boundaries. The average annual volume of streamflow that passed this station during water years 1995 through 1997 was about 5,400 acre-ft. The net difference was an annual gain of about 430 acre-ft, or about 9 percent, through the reservation. The average monthly streamflow at these gaging stations and the average monthly gain in streamflow in the reach between these gaging stations are shown in figures $4 \mathrm{~A}$ and $4 \mathrm{~B}$.

Average annual discharge at Granite Creek near Prescott (09503000) during 1933-41 and 1946 was about 4,450 acre-ft, compared with about 5,400 acre-ft during 1995-97 (fig. 5). Average annual precipitation during 1933-41 and 1946, however, was about 20.6 in. compared with 14.9 in. during 1995-97 (fig. 6). The reasons for this contradiction are unknown.

Crest-stage data from the four main tributaries indicate that most of the secondary contribution to streamflow came from two washes. Inflow to Granite Creek occurred at the culvert on the unnamed wash at the southwest boundary of the reservation and at the mouth of Government Canyon Wash near U.S. Highway 89.

\section{Surface-Water Quality}

Water temperature, specific conductance, $\mathrm{pH}$, and dissolved-oxygen concentrations did not indicate adverse water-quality conditions. Water temperatures for all sites coincided with the time of the year a site was sampled. Temperatures ranged from a low of $2.5^{\circ} \mathrm{C}$ in December to a high of $26^{\circ} \mathrm{C}$ in July. Specific conductance for site 4 on Slaughterhouse Gulch ranged from 187 to $223 \mu \mathrm{S} / \mathrm{cm}$; measurements along Granite Creek ranged from 264 to $724 \mu \mathrm{S} / \mathrm{cm}$. Biological and chemical processes are directly affected by the availability of dissolved oxygen in the water. Dissolved oxygen ranged from 4.6 to $12.8 \mathrm{mg} / \mathrm{L}$ in

Slaughterhouse Gulch and Granite Creek. The $\mathrm{pH}$ for surface water on the Yavapai-Prescott Indian
Reservation ranged from 7.2 to 8.5. The USEPA SMCL (acceptable range) for $\mathrm{pH}$ is 6.5 to 8.5 (U.S. Environmental Protection Agency, accessed May 19, 1999).

Water samples collected from the surface-water sites did not contain concentrations of any constituent that exceeded USEPA MCLs. Major-ion data for surface-water sites generally plotted in a tight group on a trilinear diagram (Piper, 1944) and indicated the prevalence of calcium magnesium bicarbonate type water (fig. 7A). General clustering of the data indicates sources of water that have potentially common processes affecting the water quality. Common processes could include surface-water runoff from similar land-surface areas, similar ground-water characteristics, and the lack of localized inflows of surface-water runoff and (or) ground water that contains human or natural inputs that would significantly alter the major-ion composition along Granite Creek. Data for the streamflow-gaging station Granite Creek near Prescott, and site 4 on Slaughterhouse Gulch for August 8, 1995, plot slightly outside of the group. The reasons for this small divergence are unknown. Data for other samples collected at these two sites, however, plot within the group (fig. 7A). During sample collection at the gaging stations on Granite Creek, discharge was considered to be base flow and no significant changes occurred in concentrations of calcium, chloride, and dissolved solids over time (fig. 8). Systematic sampling at different discharge rates would be needed to determine the degree of change in water quality along Granite Creek.

Concentrations of trace metals generally were low for all sites and sampling periods. Concentrations of dissolved arsenic in all samples were below the USEPA MCL $(0.05 \mathrm{mg} / \mathrm{L} ; 50 \mu \mathrm{g} / \mathrm{L})$ at the time of sample collection and analyses. In June 2000, however, the USEPA proposed a new MCL of $5 \mu \mathrm{g} / \mathrm{L}$ (U.S. Environmental Protection Agency, accessed June 27, 2000). One or more samples from all the surface-water sites except site 1a contained concentrations of dissolved arsenic that exceed the proposed MCL. 

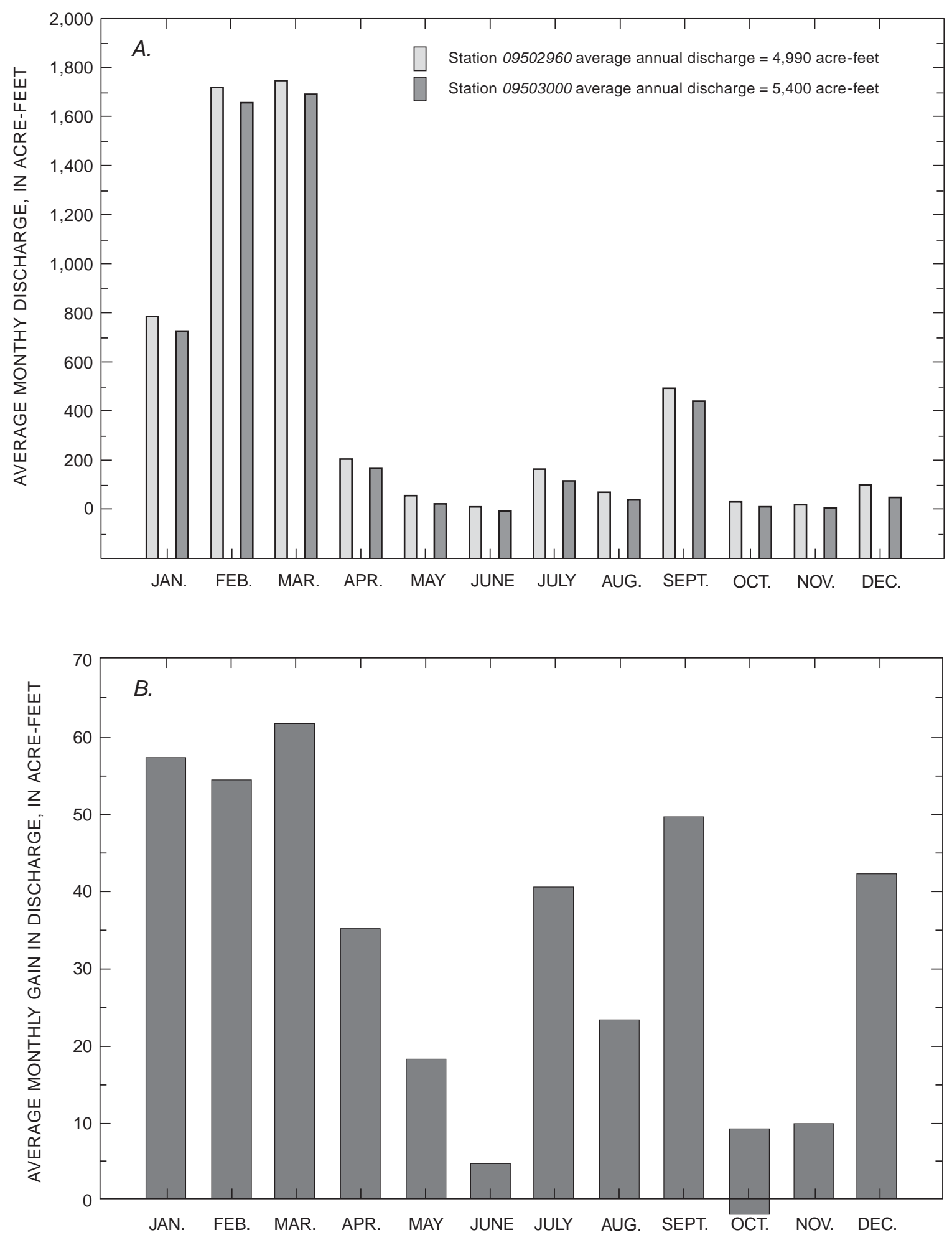

Figure 4. Average monthly discharge and average monthly gain in streamflow, Granite Creek, Arizona, water years 1995-97. A, Average monthly discharge at streamflow-gaging stations Granite Creek at Prescott (09502960) and Granite Creek near Prescott (09503000), water years 1995-97. B, Average monthly gain in streamflow in the reach of Granite Creek between streamflow-gaging stations Granite Creek at Prescott and Granite Creek near Prescott. 


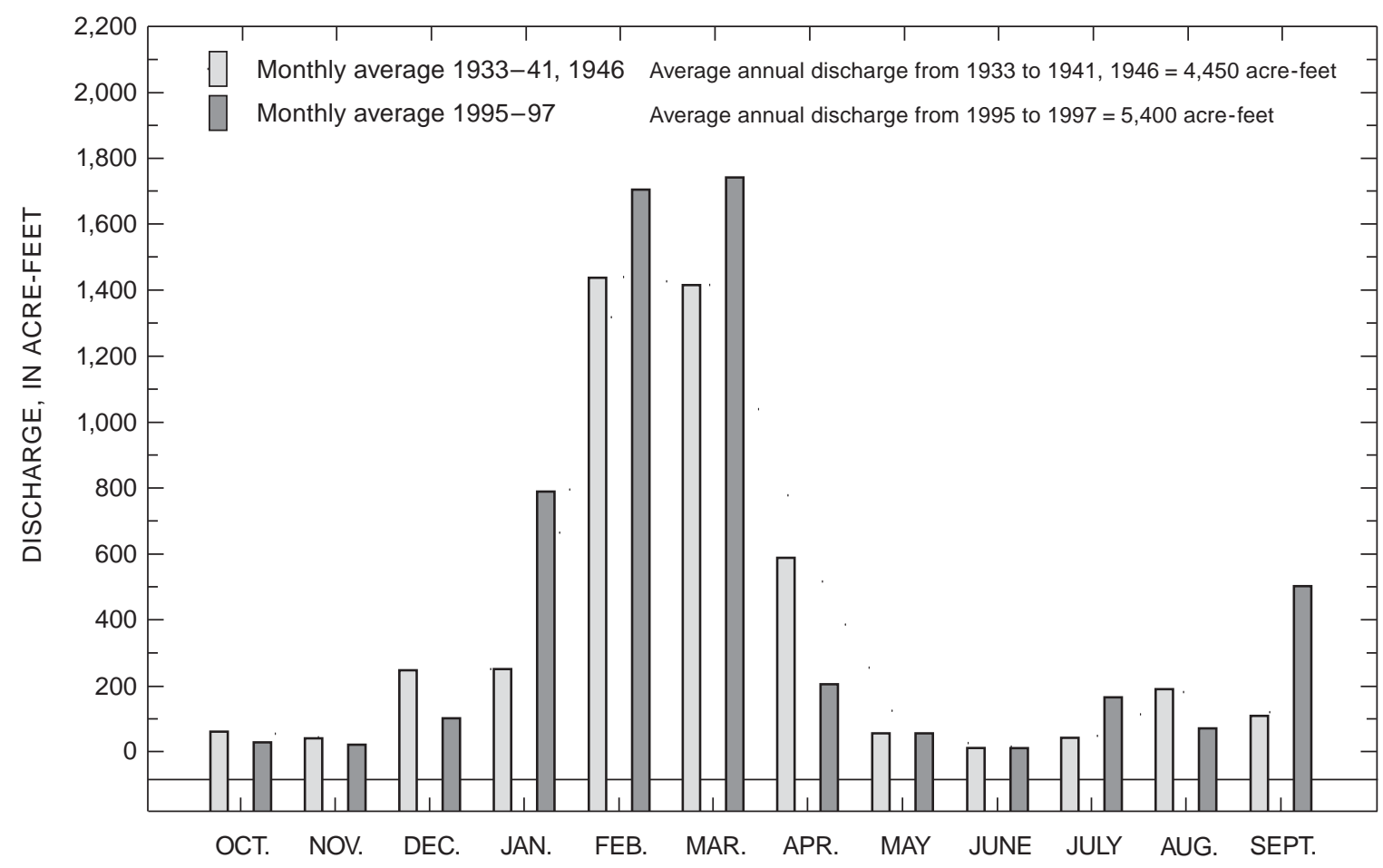

Figure 5. Average monthly discharge at streamflow-gaging station, Granite Creek near Prescott, Arizona (09503000), water years 1933-41 and 1946 and 1995-97.

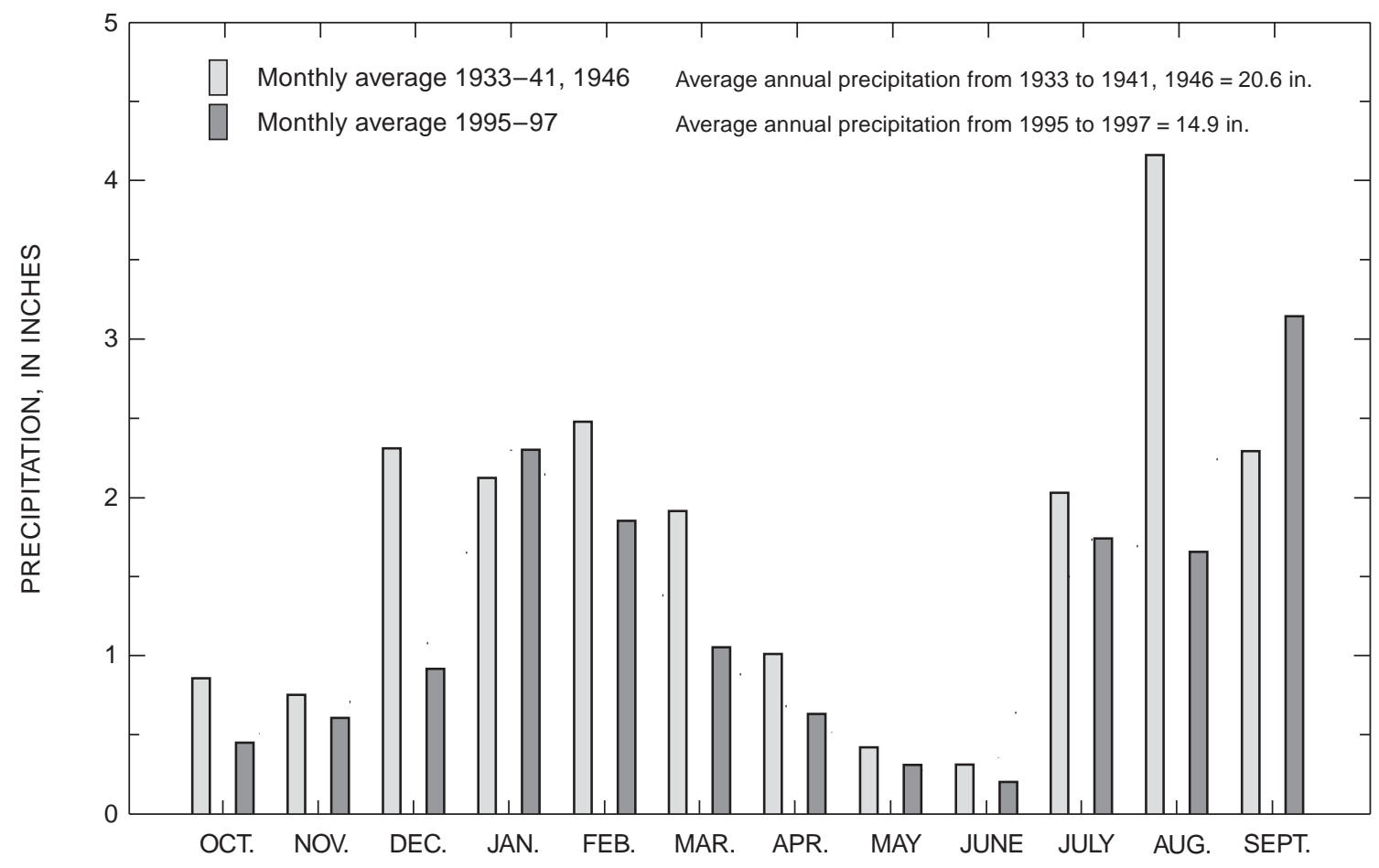

Figure 6. Average monthly precipitation at Prescott, Arizona, water years 1933-41 and 1946 and 1995-97. 

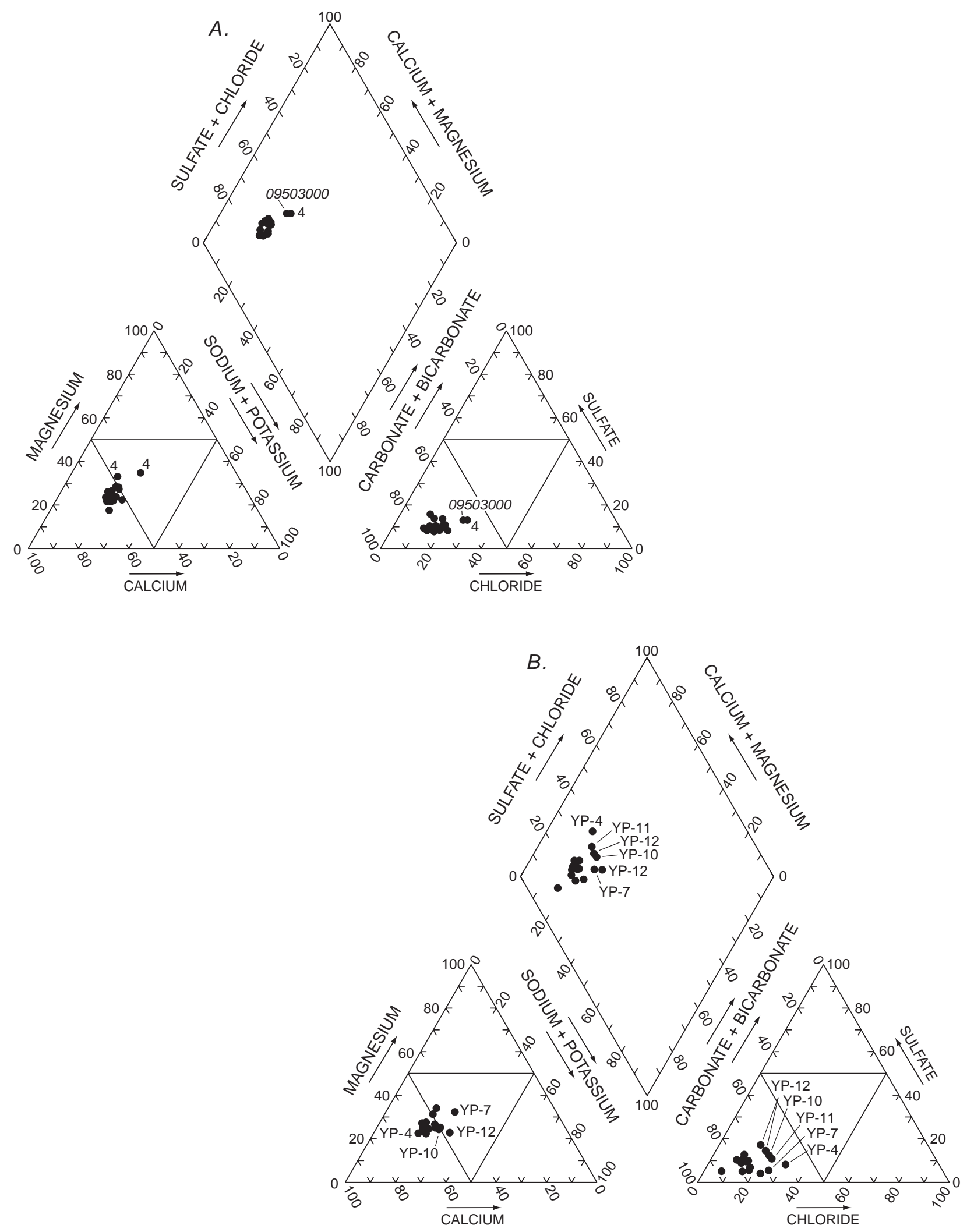

Figure 7. Relative compositions of water on the Yavapai-Prescott Indian Reservation, Arizona, 1994-98. A, Surface water. $B$, Ground water. $C$, Surface water and ground water. Number is surface-water site number or well name. 


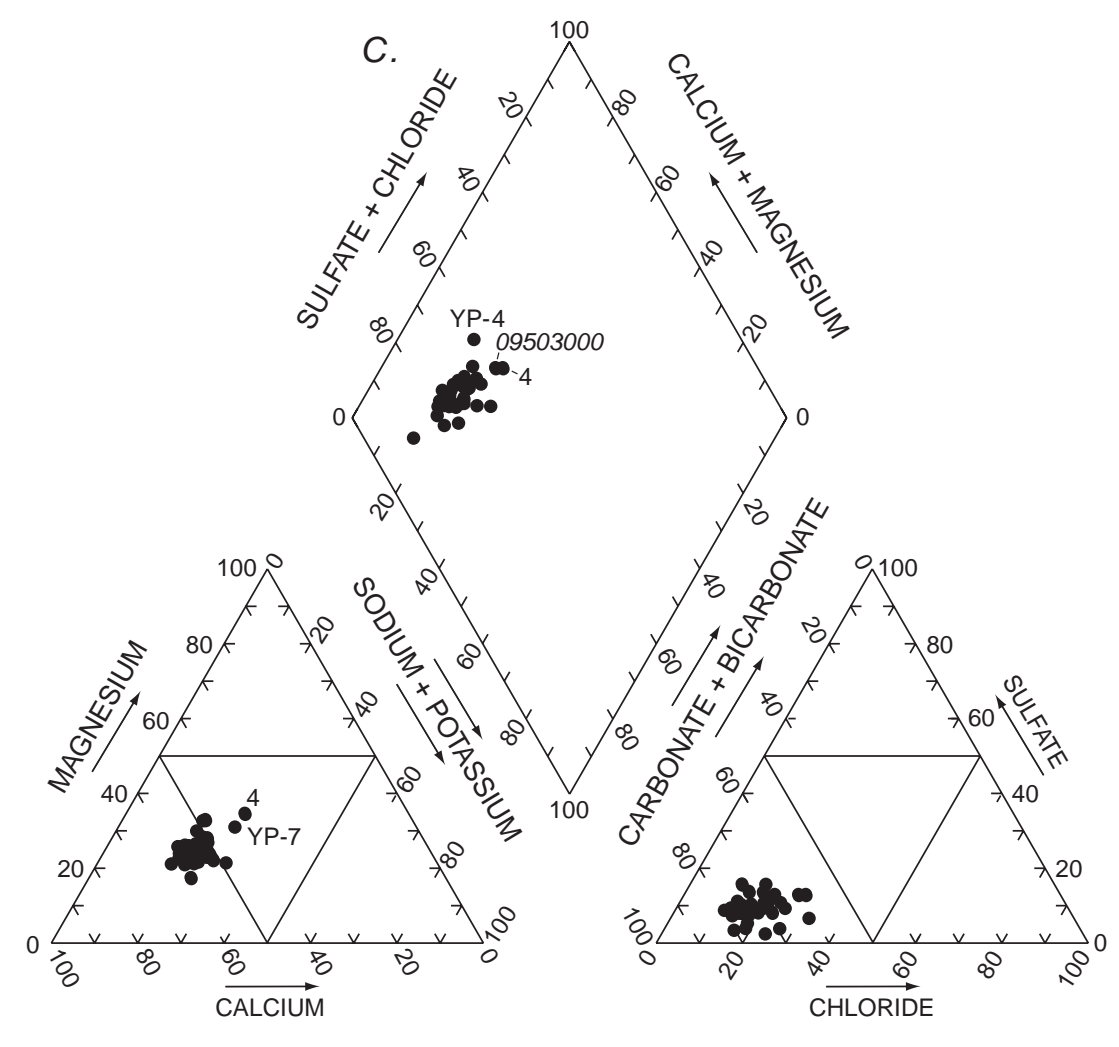

Figure 7. Continued.

Concentrations ranged from less than 1 to $10 \mu \mathrm{g} / \mathrm{L}$ in surface-water samples (table 14 in the "Basic Data" section of this report). Samples from the gaging stations and site 4 yielded slightly higher concentrations of iron (less than 3 to $240 \mu \mathrm{g} / \mathrm{L}$ ) than the other sites. Concentrations of dissolved manganese ranged from 11 to $610 \mu \mathrm{g} / \mathrm{L}$ at the surface-water sites, and the highest concentrations were at Granite Creek at Prescott (240 to $610 \mu \mathrm{g} / \mathrm{L})$. The SMCLs for iron and manganese are $300 \mu \mathrm{g} / \mathrm{L}$ and $50 \mu \mathrm{g} / \mathrm{L}$, respectively (U.S. Environmental Protection Agency, accessed May 19, 1999). Iron is not typically found in a soluble form in flowing streams that are fully aerated because of its nature to form complexes with organic material, although higher concentrations of iron associated with iron particulates small enough to pass through a 0.45 -micrometer filter do occur. Soluble manganese is more stable than ferrous iron and can be transported at higher concentrations than ferrous iron without the aid of complexation (Hem, 1985). High concentrations of dissolved iron and manganese may indicate anthropogenic input to the surface-water or ground-water system (Hem, 1985). The upstream gaging station is downgradient from the city of Prescott and samples from this station contained higher concentrations of manganese than samples from the downstream gaging station, which is at the eastern edge of the reservation. Nonpoint-source contaminants in surface-water runoff from the city of Prescott may be the main contributor of manganese to the upstream station. Elevated concentrations of iron at site 4 and at the downstream gaging station may reflect some residual component of pollution from the abandoned woodtreatment site that is upgradient from both sites. A study on point-source contaminants from a woodtreatment plant in Pensacola, Florida (Franks, 1986), found that elevated concentrations of the inorganic constituents of hydrogen sulfide, ammonia, and iron are indicative of by-products resulting from the breakdown of selected organic compounds. Nutrient concentrations were low for all sites. Concentrations of dissolved nitrate (as nitrogen) ranged from 0.58 to 0.96 , and concentrations of dissolved phosphorous ranged from less than 0.01 to $0.26 \mathrm{mg} / \mathrm{L}$. The MCL for nitrate is 10 mg/L (U.S. Environmental Protection Agency, accessed May 19, 1999). Common sources of nitrate include septic-system leaching fields, animal waste, runoff from agricultural activities, and some desert plants. Low concentrations of nitrate in Slaughterhouse Gulch and Granite Creek indicate a minimal effect from these sources. Phosphorous is commonly a byproduct of agricultural runoff. Low concentrations of phosphorous suggest minimal to no effects from agricultural activities in the area. 

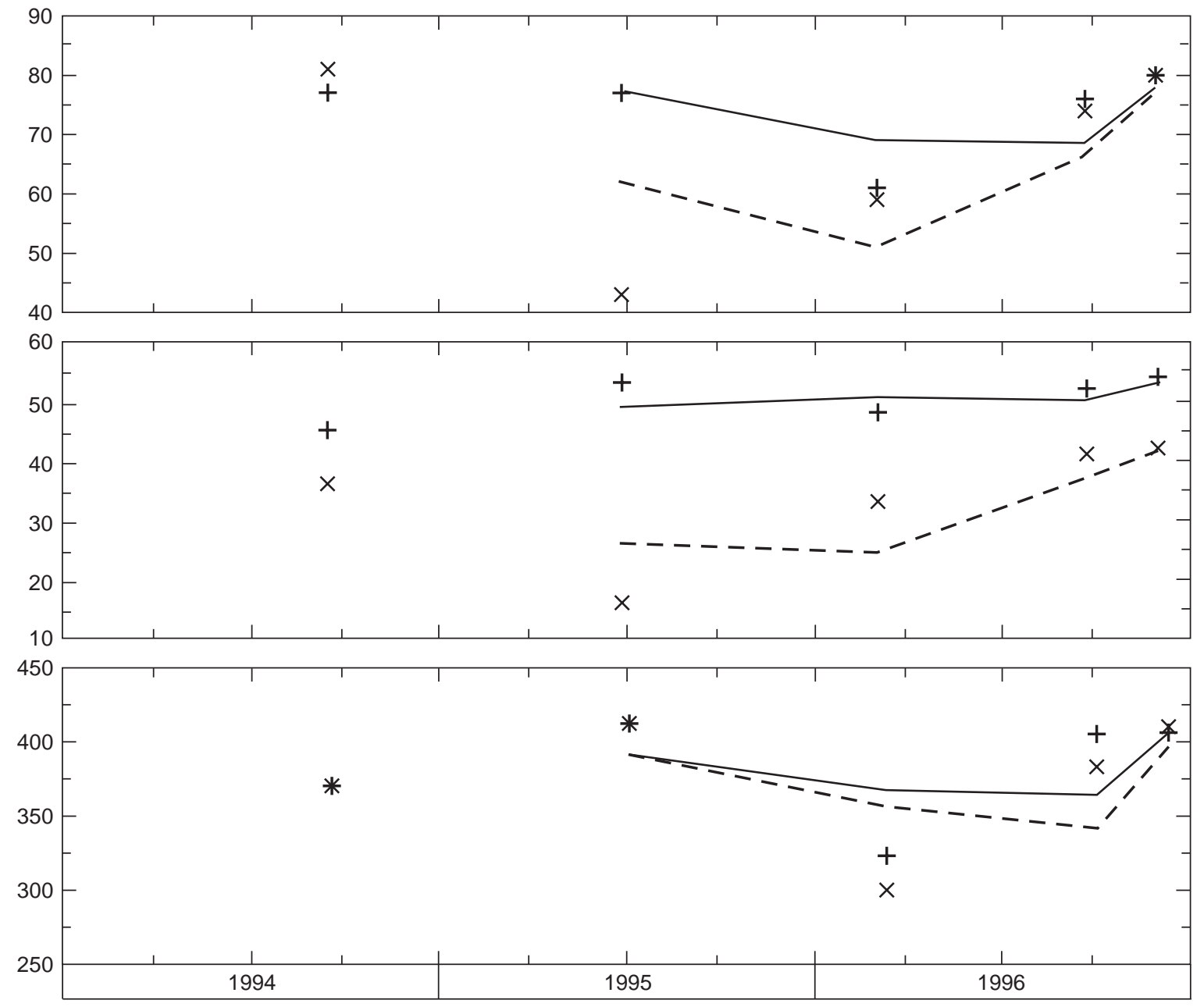

EXPLANATION

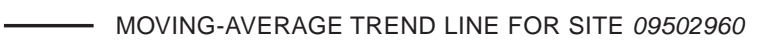

Figure 8. Concentrations of calcium, chloride, and total dissolved solids in samples from Granite Creek at Prescott (09502960) and Granite Creek near Prescott (09503000), Arizona.

Concentrations of VOCs and pesticides in surface water were below MCLs. Water from the two gaging stations contained less than 1 to $6 \mu \mathrm{g} / \mathrm{L}$ of total phenols and less than $4 \mu \mathrm{g} / \mathrm{L}$ of toluene (table 15 in the "Basic Data" section of this report). Water from sites $1 \mathrm{a}-4$ contained less than 1 to $8 \mu \mathrm{g} / \mathrm{L}$ of total phenols and no detectable concentrations of toluene. An MCL for phenol has not been established; the MCL for toluene is $1,000 \mu \mathrm{g} / \mathrm{L}$ (U. S. Environmental Protection Agency, accessed May 19, 1999). Some phenols are by-products of gasoline and wood treatment, and toluene can be a by-product of wood treatment.
Fecal streptococci (as many as 3,000 colonies/ $100 \mathrm{~mL})$ and fecal coliform (4,700 colonies/100 mL) were detected in water at the gaging stations (table 14 in the "Basic Data" section of this report). The State of Arizona surface-water quality standard for fecal coliform in a single sample is 4,000 colonies (Arizona Administrative Code, accessed May 19, 1999).

Bacterial contamination in Granite Creek has been problematic since the founding of the city of Prescott in 1874 (Yount, 1939). 


\section{Streambed-Sediment Chemistry}

Concentrations of most trace metals were low in streambed sediment from Granite Creek and Slaughterhouse Gulch. Manganese concentrations, however, ranged from $810 \mu \mathrm{g} / \mathrm{g}$ at site 3 to $1,300 \mu \mathrm{g} / \mathrm{g}$ at the gaging station Granite Creek near Prescott, and the iron concentration in the sample from the gaging station Granite Creek at Prescott, the only site for which samples were analyzed for total recoverable iron, was $27,000 \mu \mathrm{g} / \mathrm{g}$.

Phthalates, pyrenes, and phenols were detected in streambed sediment from some sites. The ranges of measured and estimated concentrations of these compounds in sediment samples from the two gaging stations and at site 3 were: 22 to $180 \mu \mathrm{g} / \mathrm{kg}$ for phthalates, 32 to $58 \mu \mathrm{g} / \mathrm{kg}$ for pyrenes, and 12 to $100 \mu \mathrm{g} / \mathrm{kg}$ for phenols (table 16 in the "Basic Data" section of this report). Laboratory results are referred to as estimates when the concentrations determined are lower or higher than the range of concentrations of the standards used to calibrate the analytical instruments. The compounds listed above are benzene derivatives, are toxic, and have the potential to cause serious health problems. The MCL for benzene in drinking water is $0.005 \mathrm{mg} / \mathrm{L}(5 \mu \mathrm{g} / \mathrm{L}$; U.S. Environmental Protection Agency, accessed May 19, 1999). The two gaging stations and site 3 were the only sites to yield detectable concentrations of organic compounds in streambed sediments of Granite Creek.

Benzene is produced from coal and is present in medicinal chemicals, dyes, and many other organic compounds including gasoline (U.S. Environmental Protection Agency, 1988). The gaging station Granite Creek at Prescott, site 3, and the gaging station Granite Creek near Prescott are directly downgradient from potential nonpoint and point sources of benzene products (the city of Prescott, the landfill at the VA Medical Center, and the abandoned wood-treatment site, respectively).

\section{Ground Water}

\section{Geophysical Interpretation}

Seismic-refraction and borehole-geophysical and lithologic methods were used to define the thickness and extent of the channel fill, valley fill, and principal water-bearing units within the reservation (figs. 9 and 10). Seismic-refraction line 1 indicated a veneer (less than $10 \mathrm{ft}$ thick) of low-velocity material (interpreted as channel fill) overlying a layer of intermediate seismic velocity (interpreted as valley fill; fig. 9). The channel fill thins and finally tapers out just north of the middle of the line. The contact between the valley fill and the lowest layer, which had the highest seismic velocity (and was interpreted as the Precambrian igneous rocks), is a poorly constrained undulating surface; therefore, the thickness of the valley fill varies, but generally is about $200 \mathrm{ft}$. Line 1 was about $300 \mathrm{ft}$ west and parallel to a fault that has uplifted and exposed a granite block east of the fault. The calculated seismic velocity of $19,093 \mathrm{~m} / \mathrm{s}$ for the Precambrian igneous rocks is not realistic. The erroneous high velocity may be due to the nonplanar nature of the surface of the Precambrian igneous rocks, poor first-break picks, or incorrect layer assignments in the modeling program (Rimrock Geophysics, Inc., 1995). First-break picks refer to the first $P$-wave returns from a refracting material and provide the best measure of depth to that material.

Seismic refraction line 2 was west of line 1 and had about the same orientation. The low-velocity channel fill beneath line 2 is thicker and more continuous than beneath line 1 and ranges from 7 to $16 \mathrm{ft}(2-5 \mathrm{~m})$ thick (fig. 9). The intermediate-velocity valley fill appears to be deposited in an asymmetrical U-shaped valley open to the south, and ranges from 16 to $197 \mathrm{ft}$ ( 5 to $60 \mathrm{~m}$ ) thick. The valley fill is thinnest at the north end of the line, thickest in the middle, and intermediate in thickness (131 ft or $40 \mathrm{~m}$ ) near the south end. The velocity calculated for the Precambrian igneous rocks below the valley fill is reasonable on the basis of estimates provided by Haeni (1988).

Line 3 was underlain by a veneer of low-velocity channel fill that overlies the intermediate-velocity valley fill (fig. 9). The intermediate-velocity zone has an undulating basal contact with the Precambrian igneous rocks. The contact is deepest at the north end of the line, shallowest just south of the center of the line, and intermediate in depth near the south end of the line. This line had the greatest variation in depth for the valley fill -52 to $315 \mathrm{ft}$ ( 16 to $96 \mathrm{~m}$ ). The calculated velocity of $34,414 \mathrm{ft} / \mathrm{s}(11,708 \mathrm{~m} / \mathrm{s})$ for the Precambrian igneous rocks is not realistic. The erroneous high velocity may be due to the nonplanar nature of the surface of the Precambrian igneous rocks, poor first-break picks, or incorrect layer assignments in the modeling program (Rimrock Geophysics, Inc., 1995). 

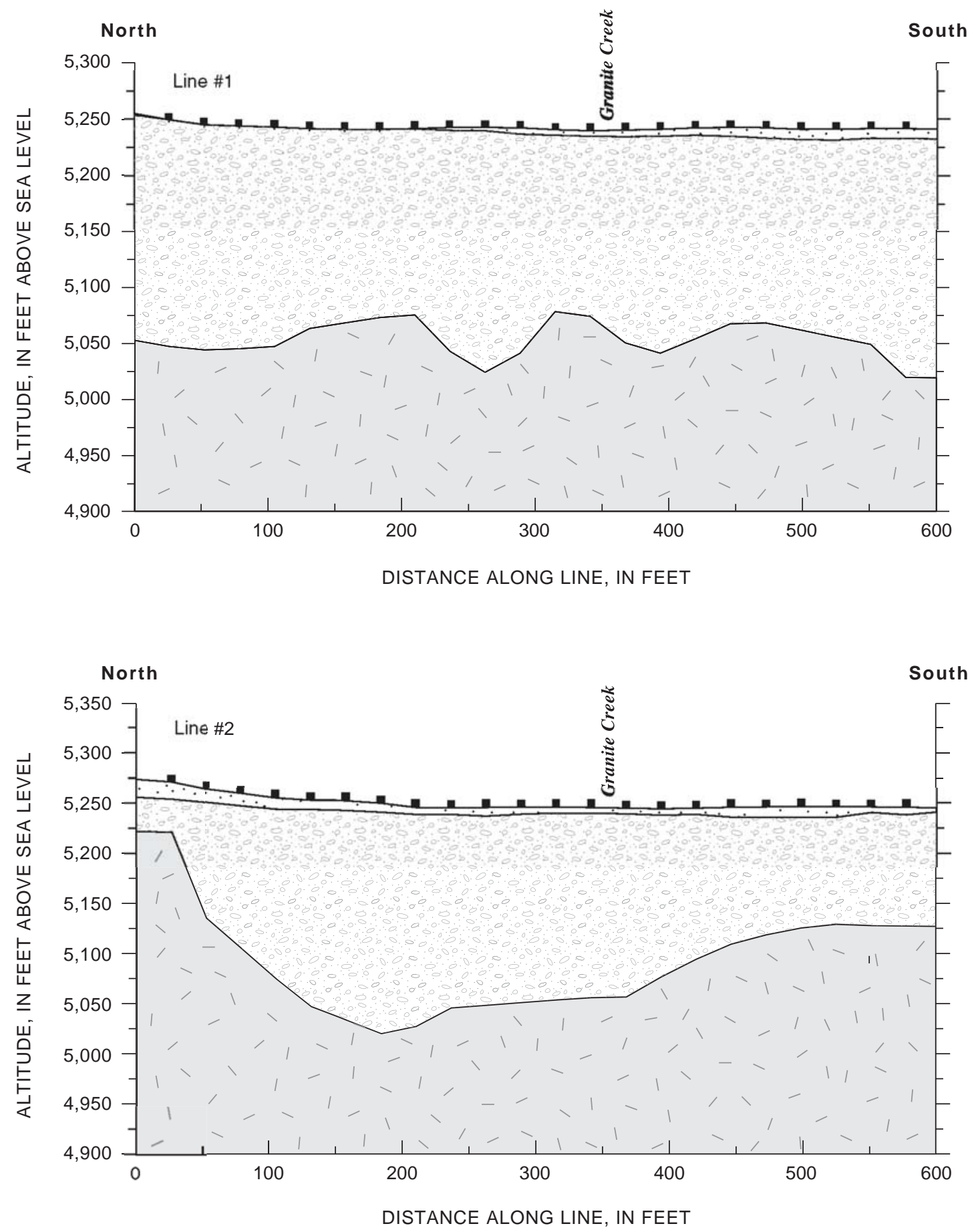

Figure 9. Seismic depth profiles along Granite Creek, Yavapai-Prescott Indian Reservation, Arizona. (See figure 2 for location of survey lines.) 

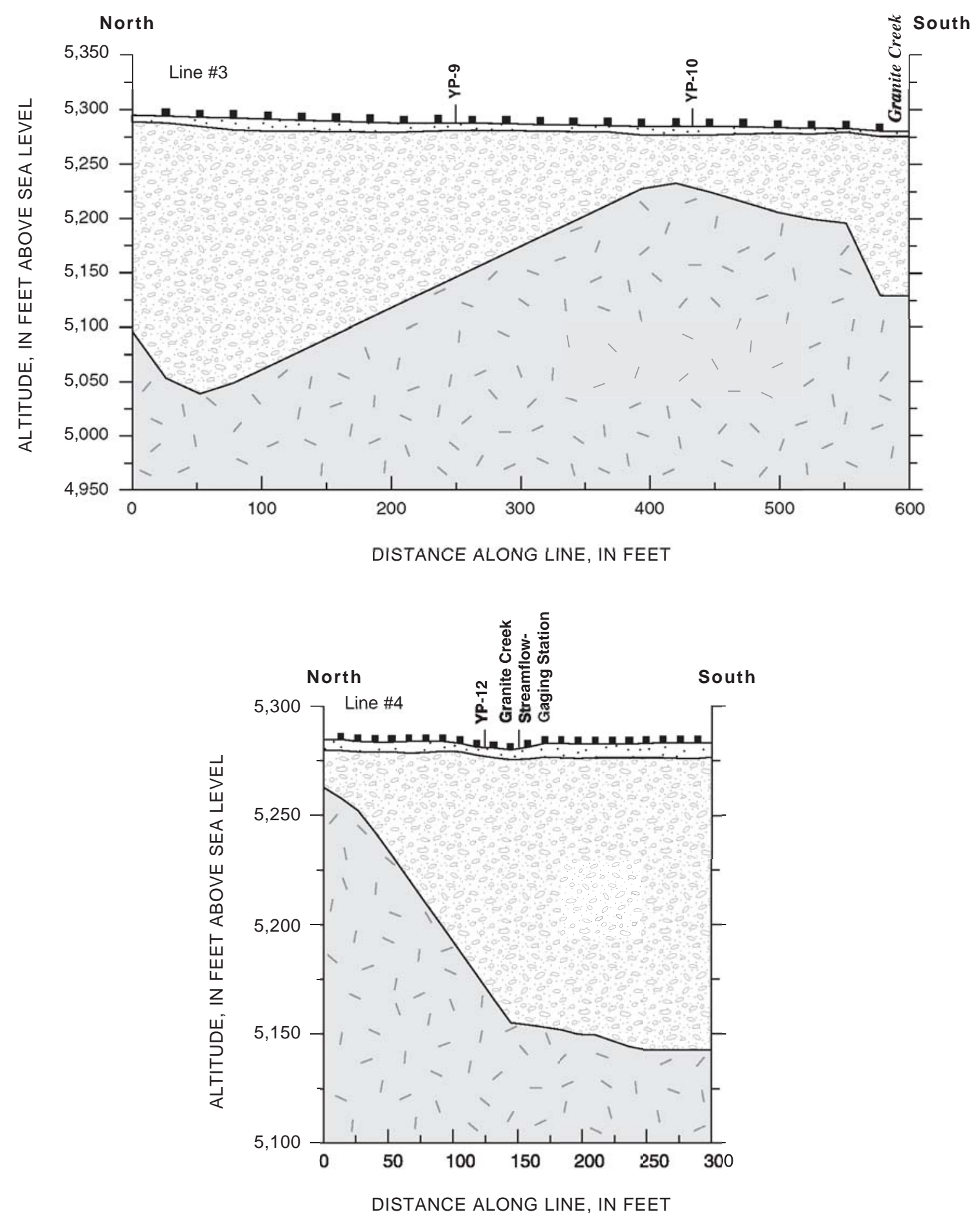

EXPLANATION

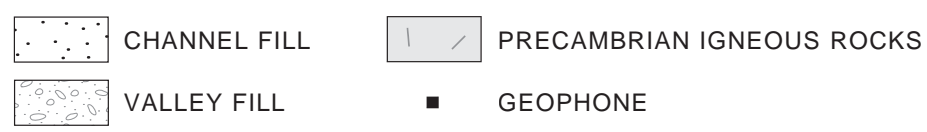

Figure 9. Continued. 


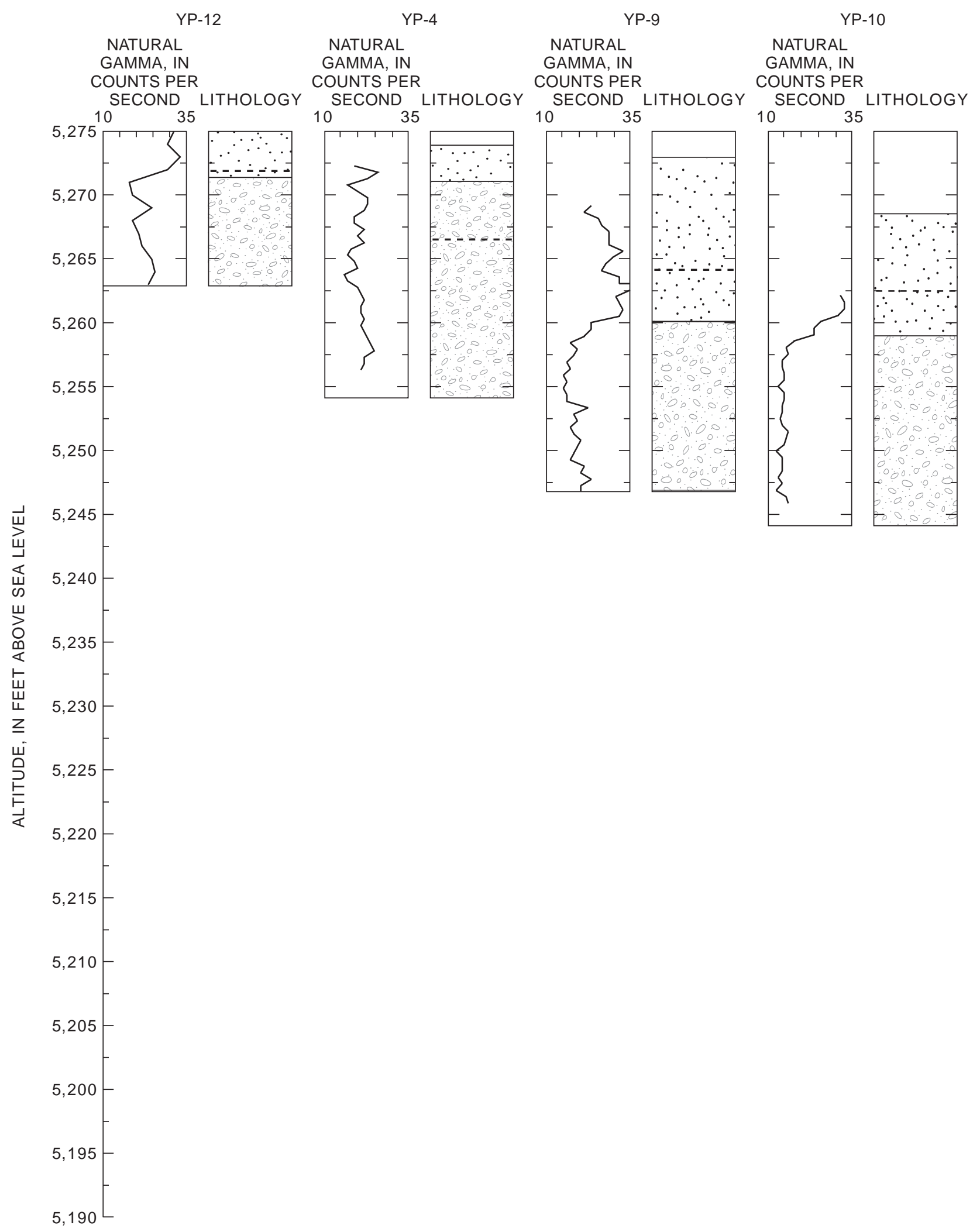

Figure 10. Gamma logs and interpreted lithology for selected wells in the Granite Creek flood plain, Yavapai-Prescott Indian Reservation, Arizona. 


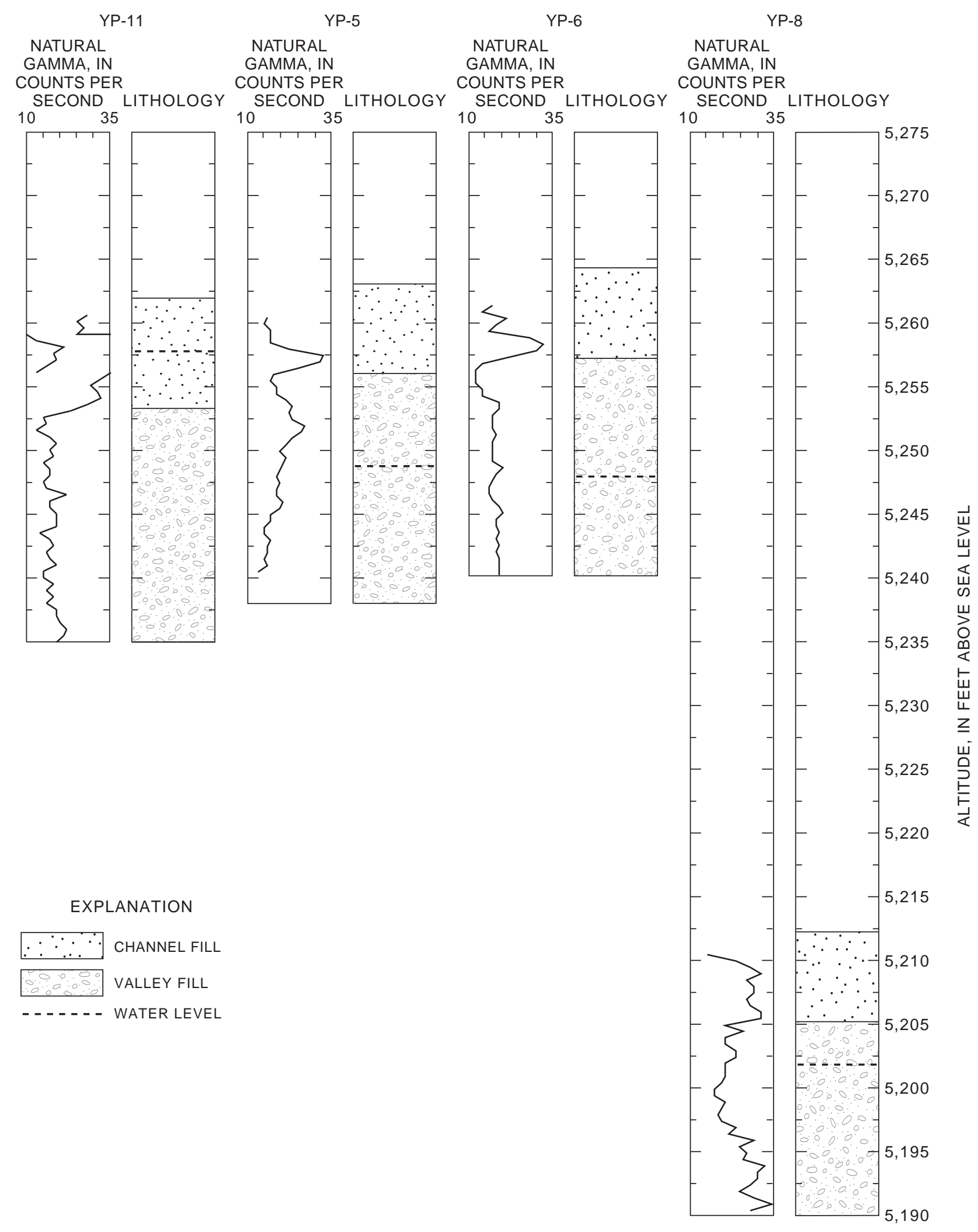

Figure 10. Continued. 
Line 4 also was underlain by a veneer of lowvelocity channel fill that overlies the intermediatevelocity valley fill. The channel fill is about $7 \mathrm{ft}(2 \mathrm{~m})$ thick along line 4 and is thinnest near the gaging station on Granite Creek. Valley fill is thinnest ( $10 \mathrm{ft}$ or $3 \mathrm{~m}$ ) on the north side of the creek and thickest $(210 \mathrm{ft}$ or $64 \mathrm{~m}$ ) near the cement plant to the south. These interpretations are consistent with the position of a granite outcrop on the north side of Granite Creek. The calculated velocity for the Precambrian igneous rocks below line 4 is reasonable.

Natural-gamma data were collected in monitor wells YP-4 through YP-6 and YP-8 through YP-12, (figs. 3 and 10) and borehole-lithologic data were compiled from well cuttings collected during the drilling of wells YP-8 through YP-12. A comparison of the known lithology to gamma counts in wells YP-8 through YP-12 provided the basis for correlating gamma counts to lithology in wells YP-4 through YP-6 (fig. 10). Results of the gamma logs show that the channel fill ranges from about 3 to $10 \mathrm{ft}$ thick at the monitor-well sites. The thicknesses of channel fill at wells YP-9, YP-10, and YP-12 determined from lithologic logs compare well with thicknesses determined from seismic lines 3 and 4 .

\section{Geohydrologic Framework}

Ground water on the reservation occurs in alluvial (channel fill and valley fill) sediments, volcanic rocks, and Precambrian igneous rocks. The principal waterbearing units are the channel fill and valley fill, and together, these units make up the principal aquifer on the reservation. These units, however, because of limited thickness (channel fill) and the presence of fine-grained material (valley fill), yield only small amounts of water to wells.

Thickness of the channel fill ranges from 0 to about $15 \mathrm{ft}$ on the basis of surface-geophysical and borehole$\log$ data. Overall, the channel-fill unit is not thick enough to provide large quantities of water to wells.

The underlying valley-fill sediments occur throughout much of the reservation and form the hillsides that flank Granite Creek. Composition of these sediments is similar to that of the overlying channel-fill sediments, but the valley fill contains more fine-grained material. On the basis of seismicrefraction data, the thickness of the valley fill is as much as $250 \mathrm{ft}$ along Granite Creek upstream from the U.S. Highway 89 bridge (fig. 9).
The valley-fill sediments are variably cemented and in some places may act as an effective barrier to the downward movement of water from the channel fill. This condition may explain the interrupted streamflow observed during periods of low flow in Granite Creek where the thickness of the channel fill varies.

Wells YP-1 and YP-3 are deep monitor wells cased for possible future use as stock-water wells (Southwest Water and Mineral Resources, 1993b). Water in these wells was reported by Southwest Water and Mineral Resources to be from upward movement along fractures in the Precambrian igneous rocks that underlie more than $100 \mathrm{ft}$ of "alluvial" sediments (Southwest Water and Mineral Resources, 1993b). Water was present at $13 \mathrm{ft}$ below land surface in the "upper alluvium" during drilling at YP-3, which is referred to as TH-2 by Southwest Water and Mineral Resources (1993b). This water level may represent the interface between the channel fill or "recent alluvium" mapped by Krieger (1965) and the older, more competent, valley fill.

Isolated remnants of volcanic rocks contemporaneous with the valley-fill sediments (Tertiary to Quaternary age) are present as caprocks near the north and south boundaries of the reservation. These volcanic rocks are not a source of water on the reservation because of their limited extent and location.

The oldest rocks exposed on the reservation are the Precambrian igneous rocks. Where buried, these rocks underlie the channel fill and valley fill. In general, the Precambrian rocks yield water only where highly fractured.

\section{Hydraulic Characteristics of the Alluvial Aquifer}

Hydraulic conductivity is the measure of the rate at which water can move through a porous material. Because aquifer materials in the study area vary in composition from place to place, the hydraulic conductivity $(K)$ also varies from place to place, and there is no one consistent value throughout the entire aquifer. Hydraulic conductivity can be calculated from the relation $K=T / \bar{D}$, where $K$ is measured in feet per day, $T$ is the transmissivity, and $D$ is the average saturated thickness of the aquifer. 
Transmissivity of the aquifer was computed iteratively for each well site from specific-capacity data as follows (Driscoll, 1986, p. 1021 formula 1):

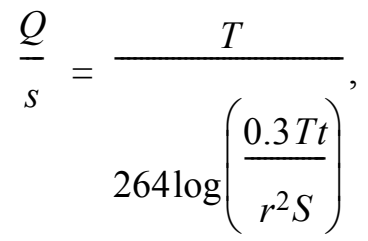

where

$$
\begin{aligned}
T & =\text { transmissivity, in feet squared per day; } \\
Q & =\text { pumping rate, in gallons per minute; } \\
s & =\text { residual drawdown, in feet; } \\
t & =\text { time since pumping started, in days; } \\
r & =\text { radius of the well, in feet, and } \\
S & =\text { storage coefficient of the aquifer. }
\end{aligned}
$$

Well YP-9 is $23.5 \mathrm{ft}$ deep, has a radius of $0.17 \mathrm{ft}$, and is screened in the channel fill and valley fill. The well produced $1.1 \mathrm{gal} / \mathrm{min}$ for 0.02 days, after which the drawdown was $7.3 \mathrm{ft}$. Using a storage coefficient of 0.2 and an initial transmissivity of $100 \mathrm{ft}^{2} / \mathrm{d}$ in the denominator, the average transmissivity calculated for this site was $10 \mathrm{ft}^{2} / \mathrm{d}$.

Well YP-10 is $22 \mathrm{ft}$ deep, has a radius of $0.17 \mathrm{ft}$, and is screened in the channel fill and valley fill. This well produced $2.5 \mathrm{gal} / \mathrm{min}$ for 0.07 days, after which the drawdown was $11.2 \mathrm{ft}$. Using a storage coefficient of 0.2 and an initial transmissivity of $100 \mathrm{ft}^{2} / \mathrm{d}$ in the denominator, the average transmissivity calculated for this site was $22 \mathrm{ft}^{2} / \mathrm{d}$.

On the basis of an average saturated thickness of $15 \mathrm{ft}$ under Granite Creek and average transmissivity values of $10 \mathrm{ft}^{2} / \mathrm{d}$ at well YP-9 and $22 \mathrm{ft}^{2} / \mathrm{d}$ at well YP-10, it was determined that the hydraulic conductivity was $0.7 \mathrm{ft} / \mathrm{d}$ at well YP-9 and $1.4 \mathrm{ft} / \mathrm{d}$ at well YP-10. These values are consistent with laboratory tests on silt-size material (Morris and Johnson, 1967). The values represent flow characteristics in the saturated part of the upper $25 \mathrm{ft}$ of the aquifer at these two wells where the thicknesses of the channel fill and valley fill (determined from seismic methods) are about 190 and $40 \mathrm{ft}$, respectively. The amount of water contributed by the channel fill or by the underlying valley fill at these wells is not known. The variation in transmissivity between these closely spaced wells probably reflects a wide variation in the composition of the channel-fill sediments throughout the flood plain.

Water levels measured October 28, 1998, in wells YP-1 through YP-12 are indicative of the hydraulic gradient within the reservation during this study (fig. 11). The hydraulic gradient is steepest in the hilly area north of Granite Creek and flattens out within the flood plain.

Flow from springs YP-301 and YP-302, which discharge from the Precambrian igneous rocks, averaged a cumulative $9.5 \mathrm{acre}-\mathrm{ft} / \mathrm{yr}$. This indicates that where sufficiently fractured, the Precambrian igneous rocks are capable of transmitting significant amounts of water.

An aquifer volume of $8.18 \times 10^{8} \mathrm{ft}^{3}$ was calculated for the area of Granite Creek between the west boundary of the reservation and the U.S. Highway 89 bridge on the basis of the thickness and aerial extent of the aquifer. Aquifer thickness was estimated using seismic-refraction data and borehole data from wells (figs. 9 and 10), and the area was determined by analysis of aerial photography provided by the U.S. Department of Agriculture (1989) and geologic data provided by Krieger (1965). Sieve analysis of well cuttings from monitor wells YP-9 through YP-12 provided grain-size data from which a weighted average porosity of 43 percent and a weighted effective porosity of 20 percent were estimated using the tables of Morris and Johnson (1967). The total storage potential for the aquifer, therefore, was estimated to be $3.52 \times 10^{8} \mathrm{ft}^{3}(8,080$ acre- $\mathrm{ft})$, and the effective storage was estimated to be $1.64 \times 10^{8} \mathrm{ft}^{3}(3,760$ acre-ft).

In 1977, seismic-refraction data were collected in conjunction with a gravel-mine land-use study along Granite Creek in the area downstream of the U.S. Highway 89 bridge north to Sundog Ranch Road (Johnson, 1977). Johnson estimated that $233,700 \mathrm{yds}^{3}$ of material had been removed since mining began in 1956, and estimated that the remaining extractable material, "to projected bedrock," was about $243,565 \mathrm{yds}^{3}$, "not including the silt terraces." This estimate is based on the assumption that the average grain-size distribution in this area is roughly the same as that upstream from the U.S. Highway 89 bridge. 


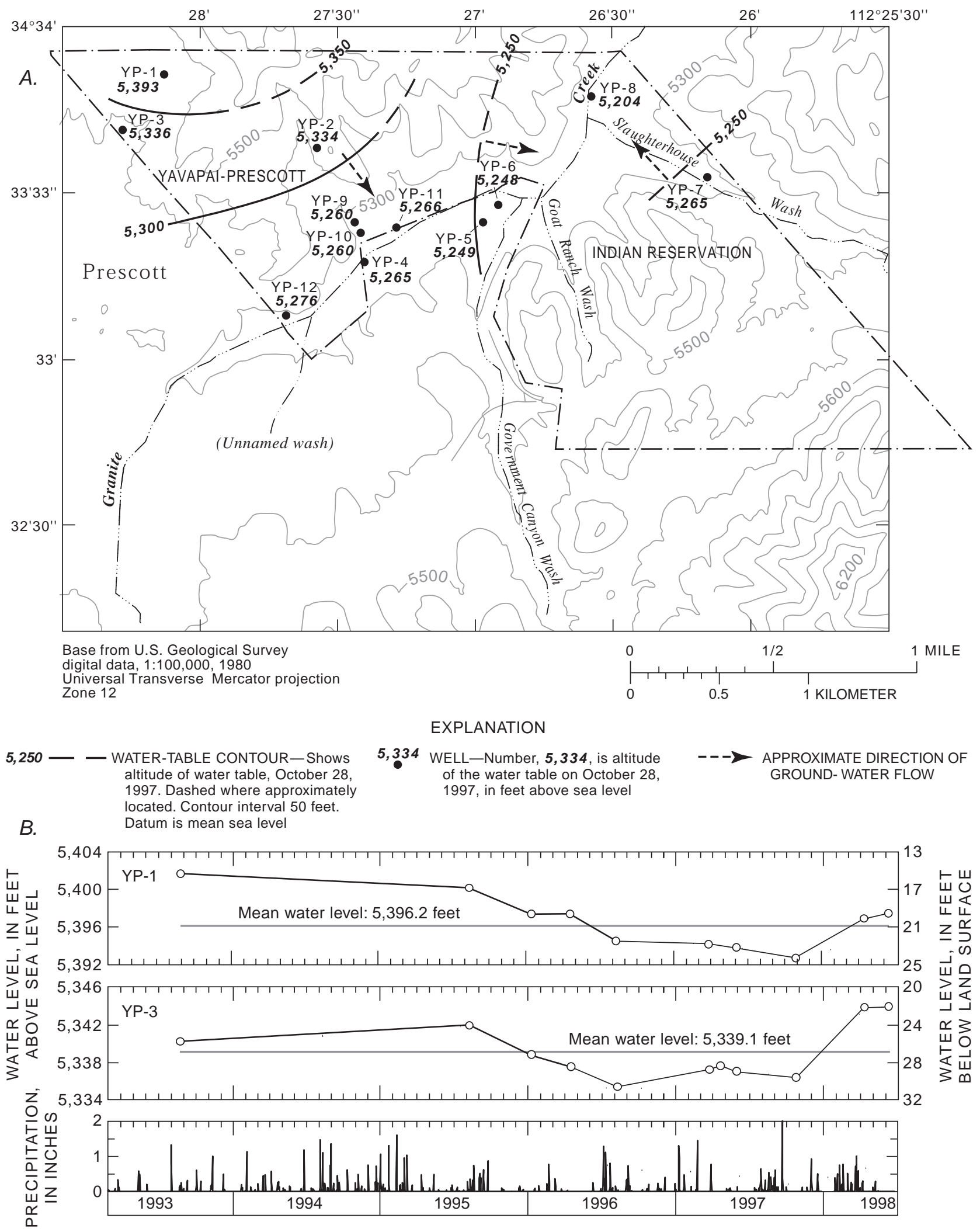

Figure 11. Altitude of the water table, water levels at wells YP-1 through YP-12, and daily precipitation, Yavapai-Prescott Indian Reservation, Arizona. A, Altitude of the water table, October 28, 1997. B, Water levels at wells YP-1 through YP-12 and daily precipitation, 1993-98. 
B. Continued.

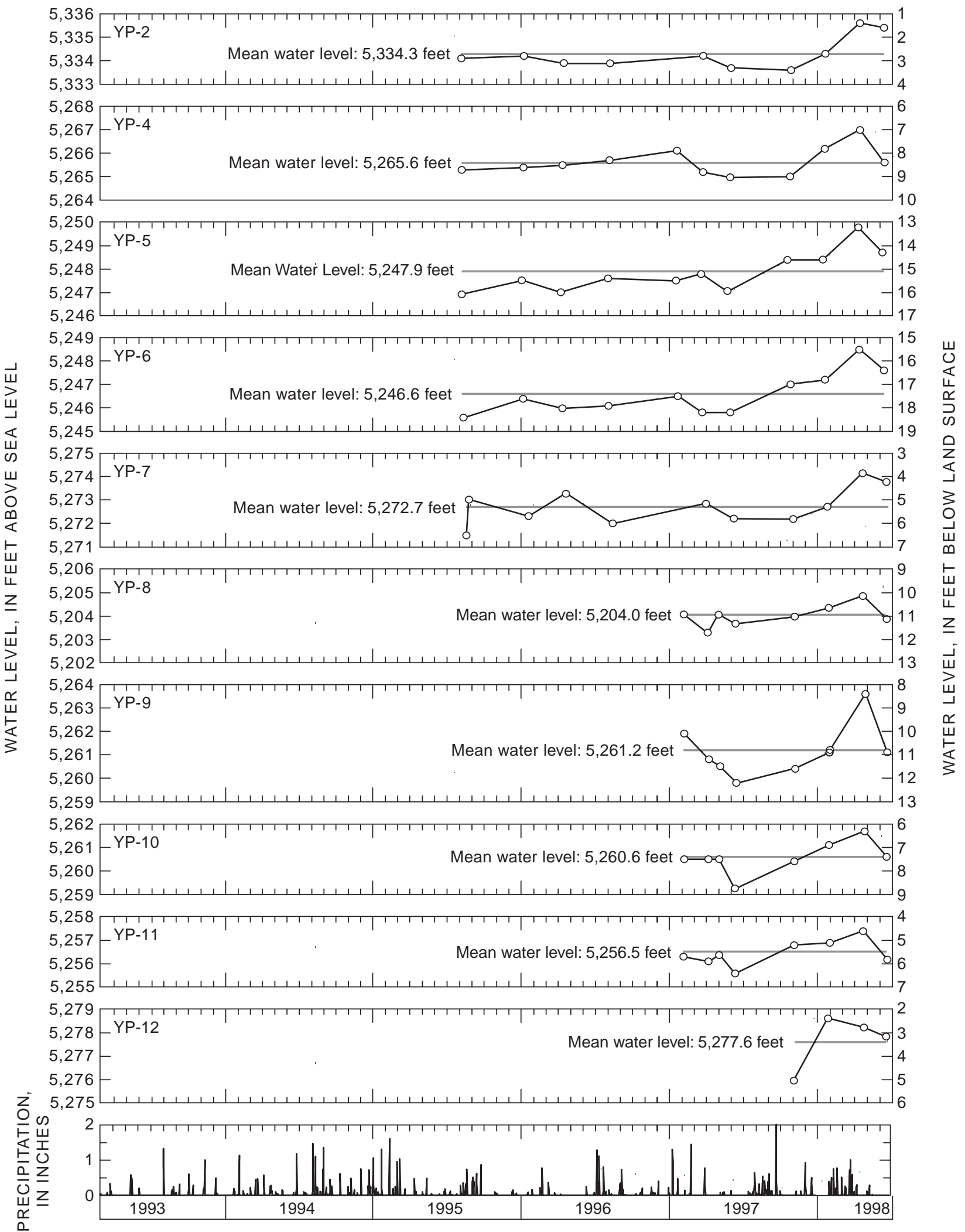

Figure 11. Continued. 


\section{Ground-Water Recharge}

Natural recharge to the channel fill and valley fill on the reservation occurs largely from infiltration of surface water along washes and flanks of the surrounding hillsides, from infiltration of precipitation into soils, and from upward movement of water from fractured igneous rocks of Precambrian age at higher elevations and along buried (paleo) channels underlying or near present-day washes. These channels can provide direct conduits for recharge from the surrounding hills, as was identified in the area underlying the abandoned Stone Container woodtreatment site in Slaughterhouse Gulch (Southwest Ground-water Consultants, Inc., 1994). Artificial recharge on the reservation occurs from infiltration of point and nonpoint discharge from industrial, irrigation, and livestock activities. Industrial activities that currently contribute to recharge include operations at the EZ Concrete plant at the west boundary of the reservation and remedial cleanup activities at the abandoned Stone Container wood-treatment site adjacent to Slaughterhouse Gulch.

Natural recharge varies throughout the reservation as a function of soil-infiltration potential. Soils along stream channels generally have a higher infiltration potential than soils elsewhere; therefore, recharge from seepage loss is greater than recharge from direct infiltration of precipitation. Overall, because Granite Creek is mainly a gaining stream within the reservation, the contribution to recharge from Granite Creek is considered to be small and occurs mostly during periods of high flow when stage surge infiltrates the embankments along the creek. This recharge is temporary and drains fairly rapidly back into Granite Creek because of the steep potentiometric gradients between the recently recharged bank sediments and the decreasing stream stage following the surge.

Recharge from irrigation is limited to that from small residential gardens and landscaping, landscaping at the Prescott Resort, and a large shopping center near the reservation's south boundary. Spring-water impoundments for livestock cause temporary redistribution of spring flow.

Rainfall averaged 14.9 in./yr for water years 1995-97 (table 1). The surface area of the reservation is about 1,440 acres. The potential average-annual volume of precipitation on the reservation, therefore, was about 1,785 acre-ft during 1995-97. The average annual streamflow on the reservation, from 1995 through 1997, was 400 acre-ft on the basis of the differences in discharges of Granite Creek between the upstream and downstream gaging stations. Subtracting the difference in average annual discharge between the upstream and downstream gaging stations (400 acre- $\mathrm{ft}$ ) from the average volume of annual precipitation (1,785 acre-ft) yields an average net flux of about 1,385 acre-ft, most of which was lost through evapotranspiration; lesser amounts were consumed by livestock and wildlife, or entered the ground as recharge.

Because rainfall intensity varies from place to place and the rain gage in Prescott is near but not on the reservation, the actual annual rainfall contribution to the reservation may be considerably different from that measured at the rain gage in Prescott. Winter (1981) states that errors associated with areal averaging of point-precipitation data can be greater than 60 percent for individual storms; however, errors in estimates of monthly precipitation probably are more in the range of 10 to 20 percent, and errors in seasonal estimates are about 5 percent.

Calculation of recharge to the channel fill and valley fill in the flood plain of Granite Creek is problematic. The few springs on the reservation issue from fractured igneous rocks of Precambrian age in areas where the overlying valley fill has been eroded away. Because more than 40 percent of the reservation is fractured Precambrian igneous rocks mantled by valley fill, the probability that buried fractures transmit water to the valley fill by upward movement from the Precambrian rocks probably is high; however, the amount of water transmitted is inestimable.

\section{Ground-Water Movement}

In general, ground water on the reservation moves in the same direction as the surface water, generally along the drainage of Granite Creek (fig. 11). This water then converges with ground water from the southwest that moves eastward and northeastward.

The portion of ground water that enters an area in the subsurface is commonly referred to as underflow. The estimated flow rate of ground water that moves through the aquifer as underflow onto the reservation from the southwest is $480 \mathrm{ft}^{3} / \mathrm{d}$ (4.0 acre- $\left.\mathrm{ft} / \mathrm{yr}\right)$ using Darcy's Law, $Q=K I A$, where $Q$ is the flow across a planar boundary, $K$ is the hydraulic conductivity, $I$ is the hydraulic gradient, and $A$ is the area of the planar boundary. This value represents only a single 
component of the overall recharge to the aquifer (see section entitled, "Ground-Water Recharge") and is based on an average flow rate $(K)$ of $1.0 \mathrm{ft} / \mathrm{d}$ for well sites YP-12 and YP-10 through an estimated area $(A)$ of $60,050 \mathrm{ft}^{2}$ and a hydraulic gradient $(I)$ of ${ }^{1} 0.008$. The area was derived from seismic-refraction data for a 300 $\mathrm{ft}$ section of the southwest boundary of the reservation coupled with data from geologic cross sections prepared by Krieger (1965).

The estimated rate at which ground water moves across the reservation is $0.04 \mathrm{ft} / \mathrm{d}$ using the following formula:

$$
V_{\text {avg }}=\frac{K I}{n}
$$

where $V_{\text {avg }}=$ average velocity and $n$ (effective porosity) is ${ }^{2} 0.2$. At that rate, it would take about 580 years for ground water to travel from the upstream boundary of the reservation to the downstream boundary, which is a distance of about $8,500 \mathrm{ft}$.

\section{Ground-Water Discharge}

There are no active production wells on the reservation or near the boundaries of the reservation. Discharge from springs and seeps provides water for livestock and wildlife; however, the amount of water consumed by livestock and wildlife is unknown. Discharge was measured eight times at two springs (YP-301 and YP-302) from 1995 to 1998 (fig. 3; table 4). Variations in discharge could be caused by seasonal fluctuations in precipitation, temperature, and (or) evapotranspiration.

Table 4. Statistical summary of spring discharge, YavapaiPrescott Indian Reservation, Arizona, 1995-98

[Discharge measurements are in gallons per minute]

\begin{tabular}{lccc}
\hline Spring name & $\begin{array}{c}\text { Minimum } \\
\text { discharge }\end{array}$ & $\begin{array}{c}\text { Maximum } \\
\text { discharge }\end{array}$ & $\begin{array}{c}\text { Mean } \\
\text { discharge } \\
\text { (eight } \\
\text { measurements) }\end{array}$ \\
\hline YP-301 & 0.9 & 2.2 & 1.6 \\
YP-302 & 1.2 & 14.8 & 4.3 \\
\hline
\end{tabular}

${ }^{1} \mathrm{Y} / \mathrm{X}$ where $\mathrm{X}$ equals the distance in feet between wells YP-12 and YP-10, and Y equals the change in water level in feet between wells YP-12 and YP-10.

${ }^{2}$ Value is based on data from sieve analyses of cuttings from wells YP-9 through YP-12 and tables in Morris and Johnson (1967).
YP-301, which is on a hillside just east of the Prescott Resort, had a mean discharge of $1.6 \mathrm{gal} / \mathrm{min}$, or $2.6 \mathrm{acre}-\mathrm{ft} / \mathrm{yr}$ during 1995-98. Water from the spring flows about $30 \mathrm{ft}$ to a series of stock-watering impoundments. YP-302, which is in a draw about $2,000 \mathrm{ft}$ east of YP-301, had a mean discharge of $4.3 \mathrm{gal} / \mathrm{min}$, or $6.9 \mathrm{acre}-\mathrm{ft} / \mathrm{yr}$ during 1995-98. The measured discharge at YP-302 may be more directly influenced by rainfall and snowmelt because of its topographic setting. Some of the measured discharge may include seepage from bank storage of precipitation in the sediments above and around the spring. Water from YP-302 flows northward about $70 \mathrm{ft}$ where it converges with ephemeral flow from nearby seeps and a highway culvert. Water can flow from these combined sources for several hundred feet on the surface before fully infiltrating channel sediments.

Annual ground-water discharge to Granite Creek was estimated by compiling the mean surface-water discharge at the downstream streamflow-gaging station (Granite Creek near Prescott; 09503000) during periods of zero flow at the upstream streamflow-gaging station (Granite Creek at Prescott; 09502690). During 1995-97, there were 115 days of zero flow recorded at the upstream station. The corresponding discharge at the downstream station ranged from 0 to $0.2 \mathrm{ft}^{3} / \mathrm{s}$ (fig. 12; table 5). The variation in discharge was mainly a function of loss due to evapotranspiration. During the 115 days, the average discharge at the downstream gaging station was $3,456 \mathrm{ft}^{3} / \mathrm{d}$. Applying this rate to every day of the year, it was estimated that about 29 acre-ft of ground water left the reservation each year as streamflow along Granite Creek. Most of the ground water that leaves the reservation each year does so during the winter months when evapotranspiration is lowest and the hydraulic head in the aquifer is higher than the stream channel. No attempt was made to estimate discharge from bank storage. Bank storage refers to the temporary storage of surface water within the embankments of Granite Creek during periods of high streamflow.

\section{Water-Level Changes}

Continuous long-term water-level records are not available for the reservation. A water-level monitoring network of 12 wells was established during this investigation (fig. 3). Seven wells (YP-1 through YP-7) were drilled before this investigation, and wells YP-8 through YP-12 were drilled during the investigation to provide additional ground-water data in the flood plain of Granite Creek. 


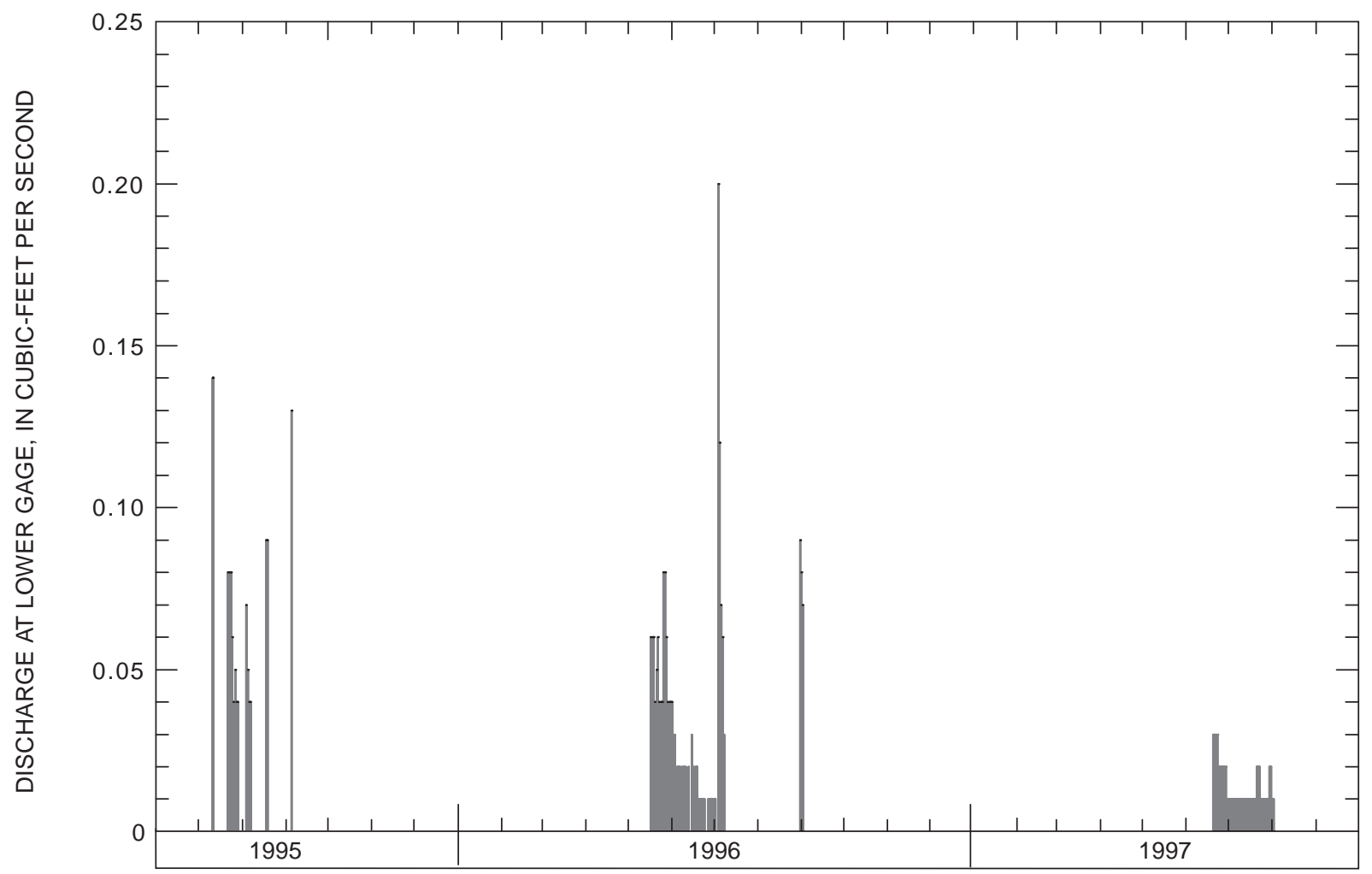

Figure 12. Discharge at Granite Creek near Prescott (09503000), during periods of zero flow at Granite Creek at Prescott (09502960), Arizona, 1995-97.

Table 5. Statistical summary of surface-water discharge at streamflow-gaging station Granite Creek near Prescott (09503000), during periods of zero flow at streamflow-gaging station Granite Creek at Prescott (09502960), Arizona, 1995-97

[Values for mean, maximum, and minimum are in cubic feet per second; ---, zero-flow criteria not met; <, less than]

\begin{tabular}{|c|c|c|c|c|c|c|c|c|c|c|c|c|c|c|c|}
\hline \multirow{2}{*}{$\begin{array}{c}\text { Monthly } \\
\text { value }\end{array}$} & \multicolumn{5}{|c|}{1995} & \multicolumn{5}{|c|}{1996} & \multicolumn{5}{|c|}{1997} \\
\hline & May & Jun. & Jul. & Aug. & Sept. & May & Jun. & Jul. & Aug. & Sept. & May & Jun. & Jul. & Aug. & Sept. \\
\hline Mean & --- & --- & 0.08 & 0.06 & 0.13 & 0.05 & 0.02 & 0.07 & 0.09 & 0.08 & --- & 0.02 & 0.01 & 0.01 & --- \\
\hline Maximum & --- & --- & .14 & .09 & .13 & .08 & .04 & .2 & .09 & .08 & --- & .03 & .02 & .01 & --- \\
\hline Minimum & --- & --- & .04 & .04 & .13 & .04 & .00 & .01 & .09 & .07 & --- & .01 & .01 & .01 & --- \\
\hline Acre-feet & --- & --- & 1.5 & .8 & .3 & 1.6 & 1.0 & 1.0 & .2 & .3 & --- & .5 & .7 & $<.1$ & --- \\
\hline
\end{tabular}

Wells YP-1, YP-2, and YP-3 are in the uplands in the northwestern part of the reservation, and YP-7 is in Slaughterhouse Gulch. All other wells are in the flood plain of the creek. Wells YP-1 and YP-3 are farthest from the flood plain of Granite Creek and had the greatest variation in water levels $(9.0$ and $8.6 \mathrm{ft}$, respectively) during the period of record (table 6).

Water levels in all wells except YP-1 generally rose during the winter season (October through April) and generally declined during the summer season (May through September). The rise in water levels during winter probably is caused by increased infiltration due to more winter precipitation and minimal rates of evapotranspiration. The decline in water levels during the summer probably is caused by decreased infiltration due to the small amount of precipitation and high rate of evapotranspiration in late spring and early summer. Infiltration of above-average precipitation, produced by storms during the El Niño-Southern Oscillation of late 1997 and early 1998, appears to have caused a rise in water levels in all monitor wells. 
Table 6. Statistical summary of ground-water levels, Yavapai-Prescott Indian Reservation, Arizona, 1993-98 [do, ditto]

\begin{tabular}{|c|c|c|c|c|c|}
\hline Well number & $\begin{array}{c}\text { Number of } \\
\text { measurements }\end{array}$ & $\begin{array}{l}\text { Minimum depth to } \\
\text { water, in feet }\end{array}$ & $\begin{array}{l}\text { Maximum depth to } \\
\text { water in feet }\end{array}$ & $\begin{array}{l}\text { Variation in depth to } \\
\text { water, in feet }\end{array}$ & Period of record \\
\hline YP-1 & 12 & ${ }^{1} 15.3$ & 24.3 & 9.0 & $8 / 93-6 / 98$ \\
\hline YP-2 & 13 & 1.4 & 3.4 & 2.0 & $8 / 95-6 / 98$ \\
\hline YP-3 & 13 & 22.1 & 30.7 & 8.6 & 8/93-6/98 \\
\hline YP-4 & 13 & 7.0 & 9.0 & 2.0 & 8/95-6/98 \\
\hline YP-5 & 13 & 13.2 & 16.1 & 2.9 & do. \\
\hline YP-6 & 13 & 15.5 & 18.4 & 2.9 & do. \\
\hline YP-7 & 13 & 10.8 & 13.5 & 2.7 & do. \\
\hline YP-8 & 24 & 10.2 & 11.8 & 1.6 & $1 / 97-6 / 98$ \\
\hline YP-9 & 13 & 8.4 & 12.2 & 3.8 & do. \\
\hline YP-10 & 13 & 6.3 & 8.8 & 2.5 & do. \\
\hline YP-11 & 13 & 4.6 & 6.4 & 1.8 & do. \\
\hline YP-12 & 8 & 2.4 & 5.1 & 2.7 & $10 / 97-6 / 98$ \\
\hline
\end{tabular}

${ }^{1}$ Reported (Southwest Water and Mineral Resources, 1993b)

Well YP-2, which is in a small unnamed tributary north of Granite Creek in the northwestern part of the reservation, is a shallow well developed at a seep near the contact between valley fill to the east and Prescott Granite to the west. Like well YP-3, YP-2 is topographically removed from the flood plain of Granite Creek; however, the water level in YP-2 responds to variations in precipitation as do water levels in wells along the flood plain (fig. 11).

Because measured water-level changes on the reservation were small, changes in ground-water storage are considered to be small, and recharge should be nearly equal to discharge.

\section{Ground-Water Quality}

Ground-water temperatures ranged from 15.5 to $20.5^{\circ} \mathrm{C}$ (table 17 in the "Basic Data" section of this report). The lowest temperature was at spring YP-301, and the highest temperature was at well YP-10. Well YP-10 had the largest range in temperature- $4-20.5^{\circ} \mathrm{C}$ in September 1997 and $16.5^{\circ} \mathrm{C}$ in June 1998. All other sites measured more than once had fairly consistent temperatures. Specific-conductance values ranged from $381 \mu \mathrm{S} / \mathrm{cm}$ at well YP-10 to $990 \mu \mathrm{S} / \mathrm{cm}$ at well YP-4. Dissolved-oxygen concentrations ranged from 0.1 to $7.6 \mathrm{mg} / \mathrm{L}$. Concentrations of dissolved oxygen were low in samples from DP-1 and DP-2 (0.1 and $0.2 \mathrm{mg} / \mathrm{L}$, respectively); both wells were drilled within a few feet of the streambed of Granite Creek. Low concentrations of dissolved oxygen indicate anaerobic conditions in the ground water. In most other wells, dissolved oxygen was between 11 and 96 percent of saturation in ground water, which indicates aerobic conditions that are typical for shallow alluvial aquifers (Hem, 1989). Values of $\mathrm{pH}$ ranged from 6.7 to 7.8 , which indicates nearly neutral to slightly above neutral (basic) conditions.

Concentrations of nitrite plus nitrate (as nitrogen) and orthophosphate in ground-water samples did not exceed $2.02 \mathrm{mg} / \mathrm{L}$. Nutrients typically enter the ground water from recharging surface waters. Low concentrations of nitrate and phosphate indicate that sources such as septic systems, animal waste, and agriculture are not substantially affecting the overall quality of ground water in the study area.

Major ions plot in tight groups on a trilinear diagram (Piper, 1944) and indicate a predominantly calcium magnesium bicarbonate water type (fig. 7B). Water from wells YP-4, YP-7, YP-10, YP-11, and YP-12 contained slightly higher concentrations of chloride than water from other wells. Studies (Kuroda and Sandell, 1953; Feth, 1965) have shown that weathering of most rocks does not typically produce high concentrations of chloride to natural waters, and 
that human input is a more likely source. Water from well YP-4 contained the highest concentration of chloride $(110 \mathrm{mg} / \mathrm{L}$; table 17 in the "Basic Data" section of this report). Well YP-4 is downgradient from the cement plant, which may provide concentrations of chloride as by-products from surface runoff.

Concentrations of dissolved barium, cadmium, and chromium in ground-water samples were low relative to USEPA MCLs; arsenic and manganese concentrations were high. The concentration of total arsenic was high in water from well YP-12 in $1997(1,300 \mu \mathrm{g} / \mathrm{L}$; table 17 in the "Basic Data" section of this report). The dissolved concentrations of arsenic at this well (24 $\mu \mathrm{g} / \mathrm{L}$ in 1997; $7 \mu \mathrm{g} / \mathrm{L}$ in 1998) were much lower than the total concentrations. The concentrations of dissolved arsenic in all samples were below the MCL $(0.05 \mathrm{mg} / \mathrm{L} ; 50 \mu \mathrm{g} / \mathrm{L} ; \mathrm{U} . S$. Environmental Protection Agency, accessed May 19, 1999) at the time of sample collection and analysis. Six of the samples contained concentrations that exceed the proposed new MCL of $5 \mu \mathrm{g} / \mathrm{L}$ (U.S. Environmental Protection Agency, accessed June 27, 2000). Differences between the total and dissolved concentrations of arsenic may result from mobility of solids during pumping of the well. Processes contributing arsenic to the ground water are difficult to define but may include weathering of local rocks (for example, arsenopyrite often found in granites) and (or) transport of pesticides through infiltration of surface water (Hem, 1989). Manganese concentrations in samples from wells YP-8 $(2,320 \mu \mathrm{g} / \mathrm{L}), \mathrm{YP}-11(547 \mu \mathrm{g} / \mathrm{L}), \mathrm{YP}-12(328 \mu \mathrm{g} / \mathrm{L})$, spring YP-301 $(330 \mu \mathrm{g} / \mathrm{L})$, and the two drive-point wells (DP-1, $850 \mu \mathrm{g} / \mathrm{L}$; DP-2, $330 \mu \mathrm{g} / \mathrm{L}$ ) exceeded the SMCL of $5.0 \mu \mathrm{g} / \mathrm{L}$ (U.S. Environmental Protection Agency, accessed May 19, 1999). Processes similar to those involving arsenic probably are the cause of these manganese concentrations. The lack of high iron concentrations in the ground water may indicate that different types of geochemical environments are present that would cause iron to behave differently in ground water and surface water.

Concentrations of VOCs and SVOCs were detected in water from some springs and wells (table 18 in the "Basic Data" section of this report). Toluene was detected in water from spring YP-4a and wells YP-7, YP-8, YP-9, and YP-10 (1.20, 0.6, 0.4, 1.3, and $2.1 \mu \mathrm{g} / \mathrm{L}$, respectively). Phenol was detected in water from well YP-4 $(1 \mu \mathrm{g} / \mathrm{L})$, and xylene was detected in water from wells YP-7 and YP-8 (1.00 and $0.5 \mu \mathrm{g} / \mathrm{L}$, respectively). The MCLs for toluene and xylene are
$1,000 \mu \mathrm{g} / \mathrm{L}$ and $10,000 \mu \mathrm{g} / \mathrm{L}$, respectively (U.S. Environmental Protection Agency, accessed May 19, 1999). An MCL has not been established for phenol. Toluene, xylene, and phenol may enter the environment from industrial discharges, municipal waste-treatment plant discharges, or spills (U.S. Environmental Protection Agency, 1989). Possible nonpoint and point sources for toluene, phenol, and xylene in the study area include surface runoff from the city of Prescott, the landfill at the VA Medical Center, the Yavapai Gaming Center, and the abandoned wood-treatment site.

Concentrations of tetrachloroethylene, trichloroethylene, and methyltertbutylether $(1.8 \mu \mathrm{g} / \mathrm{L}$, $0.60 \mu \mathrm{g} / \mathrm{L}$, and $0.30 \mu \mathrm{g} / \mathrm{L}$, respectively) were detected in water from spring YP-301. The MCLs for tetrachloroethylene and trichloroethylene are $5 \mu \mathrm{g} / \mathrm{L}$. An MCL has not been established for methyltertbutylether. Concentrations of 1,1,1-trichloroethane $(3.35 \mu \mathrm{g} / \mathrm{L})$ and 1,1 -dichloroethane $(2.48 \mu \mathrm{g} / \mathrm{L})$ were detected at well YP-8. The MCLs for 1,1,1-trichloroethane and 1,1-dichloroethane are $1.2 \mu \mathrm{g} / \mathrm{L}$ and $7 \mu \mathrm{g} / \mathrm{L}$, respectively. Concentrations of trichlorofluoromethane were detected at well YP-6 $(0.9 \mu \mathrm{g} / \mathrm{L})$ and from drivepoint well DP-2 $(0.3 \mu \mathrm{g} / \mathrm{L})$. An MCL has not been established for trichlorofluoromethane. Concentrations of cis-1,2-dichloroethane, trichloroethylene, and napthalene were detected at spring YP-4a (1, 0.6, and $0.8 \mu \mathrm{g} / \mathrm{L}$, respectively). The MCL for cis-1,2-dichloroethane is $5 \mu \mathrm{g} / \mathrm{L}$. An MCL has not been established for napthalene. Chloroform was detected in water from well YP-1 $(0.4 \mu \mathrm{g} / \mathrm{L})$. An MCL has not been established for chloroform. These compounds are used in degreasers and other products. Tetrachloroethylene is also associated with dry cleaning solvents used on fabrics and textiles. Trichloroethylene also is associated with textiles and adhesives. Trichloroethane also is associated with glue, paint, and aerosol sprays. Dichloroethane also is used to make vinyl chloride and other chemicals and to dissolve paint and varnish and finish removers (Agency for Toxic Substances and Disease Registry, accessed February 14, 2000).

\section{Surface-Water/Ground-Water Relations}

Most of the surface water on the reservation flows into Granite Creek. Most of the ground water on the reservation is stored in the unconsolidated sediments that underlie Granite Creek and its flood plain. 
Calculations have shown that Granite Creek generally gains water as ground water discharges from the surrounding alluvial sediments where the water table intersects the stream channel.

Water moves into the Granite Creek area of the reservation as a result of (1) rainfall, (2) snowmelt, (3) streamflow, or (4) runoff from upgradient areas on and near the reservation. Water from rainfall and snowmelt enters the ground-water system through permeable soils or through fractures in the Precambrian igneous rocks. Most of the water, however, either evaporates back into the atmosphere or runs off as surface flow. As the surface water moves across the flood plain or along stream channels, some may become diverted and temporarily stored in the sediments along the banks and terraces of Granite Creek. In the days following periods of high streamflow, much of the stored water drains back into Granite Creek and flows off the reservation. During the spring and summer months, some of this water is lost to transpiration and evaporation.

Water levels in wells appear to show a response to changes in the stage of Granite Creek (fig. 13) and flow in tributaries of Granite Creek (table 7). The long and irregular measurement intervals, however, may mask a more well defined water level/stage relation.

During this investigation, water-quality analyses were used as an independent means of determining the surface water/ground water relations in the area of the reservation near Granite Creek. Recharge water moves from the land surface through the unsaturated zone and into the saturated zone at the ground-water table. During this movement, water dissolves the geologic material with which it comes into contact, and minerals are dissolved and become part of the chemical makeup of the ground water. Recharge water also may carry contaminants from the surface and (or) the unsaturated zone to the ground-water table. Contaminants can potentially move from ground water to surface water, such as in the Slaughterhouse Gulch area where surface flow derives from ground-water discharge in an area where ground-water samples contained VOCs and SVOCs.

Water-quality data for surface-water and groundwater sites in the study area generally plot in a tight group on a trilinear diagram (Piper, 1944; fig. 7C). This grouping suggests a direct hydraulic connection between the surface-water and ground-water systems in the area, as well as similar processes controlling the overall water quality. These processes include water and rock interactions and a recharge regime that consistently transports similar constituents from the unsaturated zone to the ground-water system.

Plotting major-ion concentrations in Stiff (1951) diagrams on a map provides a method for spatially examining similarities and differences in water quality from the various sampling sites (fig. 14). The sizes of the diagrams, when the diagrams are plotted at the same scale, show the relative differences in concentrations of the dissolved constituents in each sample - the larger the pattern, the greater the individual constituent concentration. Similarities in the sizes and shapes of the Stiff diagrams are an indication that similar processes are controlling the water quality. The similarity in the shapes of the diagrams on figure 14 shows the similarity in the quality of the surface water and ground water on the reservation and indicates that similar processes control the quality of surface water and ground water.

Boxplots were drawn to compare ranges of $\mathrm{pH}$ and selected constituent concentrations in surface-water samples with those of ground-water samples (fig. 15). The median $\mathrm{pH}$ and the median concentration of dissolved oxygen were higher in surface-water samples, and the median concentrations of bicarbonate, calcium, sulfate, and dissolved solids were higher in ground-water samples.

\section{Influences on Water Quality}

Human activities have influenced water quality on the Yavapai-Prescott Indian Reservation throughout most of the twentieth century. For example, Yount (1939) recounts "March 2, 1903, the U.S. Quartermaster of Whipple advised the (Prescott) City Council that the present sewer outlet must be removed from Whipple (Yavapai-Prescott) Reservation." Yount further recounts, "September 11, 1905, there was so much typhoid in Prescott, considered largely due to water from Granite Creek well," that the Yavapai County Medical Society urged immediate discontinuance of use of the city well. The city well was at West Aubrey Street about $150 \mathrm{ft}$ east of Granite Creek and 1 mi upstream from the present-day reservation. 


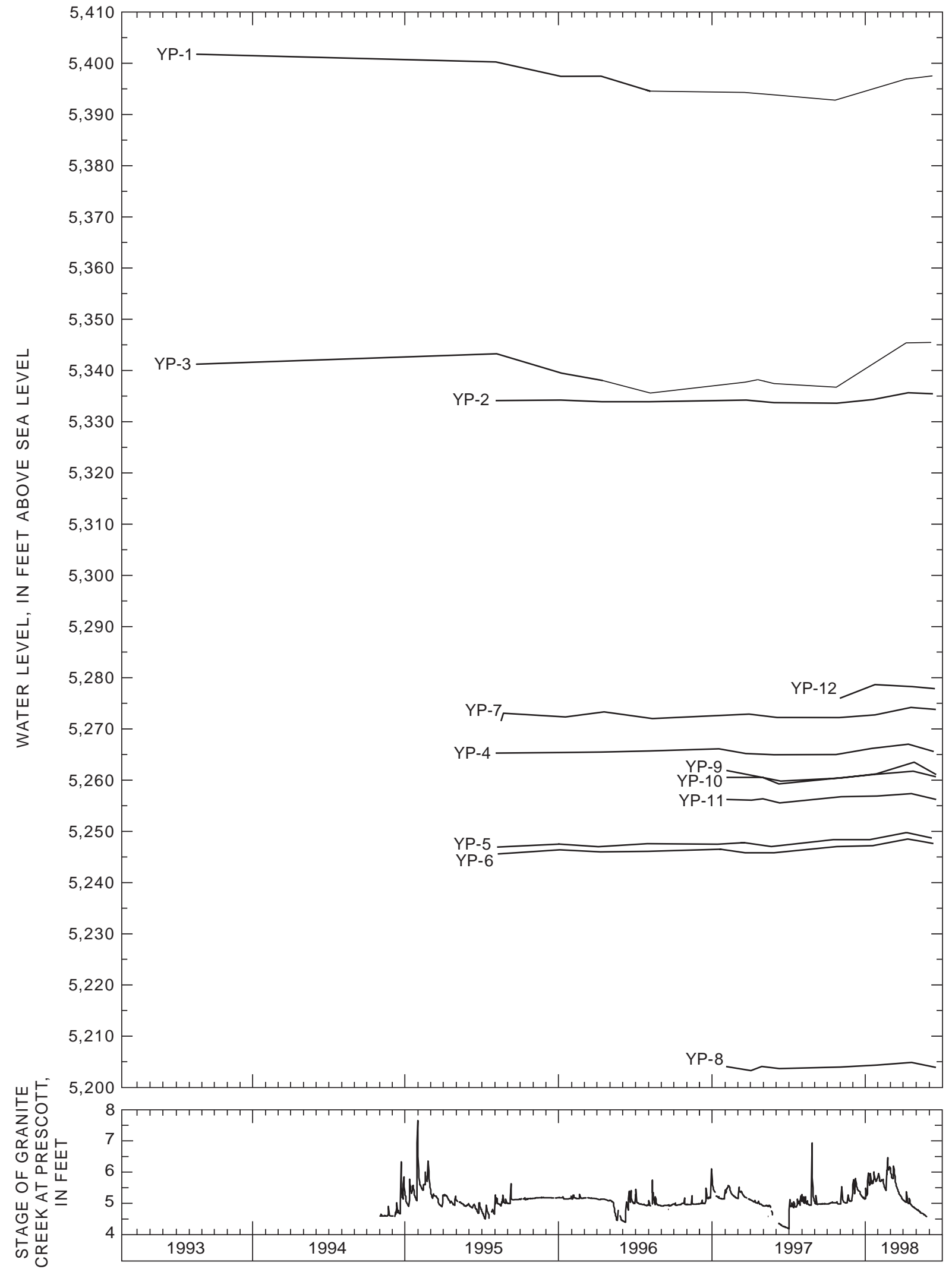

Figure 13. Water levels at wells YP-1 through YP-12, Yavapai-Prescott Indian Reservation, and stage of Granite Creek at streamflow-gaging station Granite Creek at Prescott (09502960), Arizona, 1994-98. 
Table 7. Data from crest-stage gages on tributaries of Granite Creek, Yavapai-Prescott Indian Reservation, Arizona, 1995-98

[Crest-stage data were recorded at time of site visit and represent flows that occurred since the previous site visit. WY, water year; Qtr, quarter; NV, no evidence of flow and no visual inspection of gage; ---, no flow]

\begin{tabular}{|c|c|c|c|c|c|c|c|c|c|c|c|c|c|c|c|}
\hline \multirow[b]{3}{*}{$\begin{array}{l}\text { Crest-stage } \\
\text { gage site }\end{array}$} & \multicolumn{15}{|c|}{ Stage, in feet } \\
\hline & \multicolumn{4}{|c|}{ WY 1995} & \multicolumn{4}{|c|}{ WY 1996} & \multicolumn{4}{|c|}{ WY 1997} & \multicolumn{3}{|c|}{ WY 1998} \\
\hline & 1st Otr & 2nd 0tr & 3rd 0tr & 4th Qtr & $\begin{array}{l}\text { 1st } \\
\text { Qtr }\end{array}$ & 2nd Otr & $\begin{array}{l}\text { 3rd } \\
\text { Otr }\end{array}$ & 4th Otr & $\begin{array}{l}\text { 1st } \\
\text { 0tr }\end{array}$ & $\begin{array}{l}\text { 2nd } \\
\text { Otr }\end{array}$ & $\begin{array}{l}\text { 3rd } \\
\text { Otr }\end{array}$ & $\begin{array}{l}\text { 4th } \\
\text { Otr }\end{array}$ & 1st Qtr & $\begin{array}{l}\text { 2nd } \\
\text { Otr }\end{array}$ & $\begin{array}{l}\text { 3rd } \\
\text { Otr }\end{array}$ \\
\hline Goat Ranch Wash & 0.03 & $\begin{array}{r}0.22 \\
.12\end{array}$ & 0.06 & $\begin{array}{r}0.12 \\
.44\end{array}$ & $\mathrm{NV}$ & 0.29 & --- & $\begin{array}{l}0.54 \\
--- \\
---\end{array}$ & NV & $\mathrm{NV}$ & $\mathrm{NV}$ & NV & 0.24 & 0.17 & 0.16 \\
\hline $\begin{array}{l}\text { Government } \\
\text { Canyon Wash }\end{array}$ & .30 & $\begin{array}{r}.98 \\
1.22\end{array}$ & $\mathrm{NV}$ & $\begin{array}{l}.04 \\
.69\end{array}$ & $\mathrm{NV}$ & .79 & --- & $\begin{array}{l}.85 \\
.88 \\
.09\end{array}$ & $\mathrm{NV}$ & $\mathrm{NV}$ & $\mathrm{NV}$ & $\mathrm{NV}$ & .67 & .13 & .45 \\
\hline $\begin{array}{l}\text { Slaughterhouse Gulch } \\
\text { (upstream gage) }\end{array}$ & --- & $\begin{array}{l}.32 \\
.45\end{array}$ & $\mathrm{NV}$ & $\begin{array}{r}.10 \\
2.32\end{array}$ & $\mathrm{NV}$ & 1.22 & --- & $\begin{array}{r}1.50 \\
.02 \\
.04\end{array}$ & NV & $\mathrm{NV}$ & .12 & $\mathrm{NV}$ & 1.15 & .39 & .59 \\
\hline $\begin{array}{r}\text { Slaughterhouse Gulch } \\
\text { (downstream gage) }\end{array}$ & --- & .53 & --- & $\begin{array}{r}.06 \\
1.28\end{array}$ & $\mathrm{NV}$ & 1.11 & --- & $\begin{array}{l}1.17 \\
--- \\
.17\end{array}$ & $\mathrm{NV}$ & $\mathrm{NV}$ & --- & $\mathrm{NV}$ & .68 & --- & .47 \\
\hline Unnamed Wash & .22 & $\begin{array}{l}.31 \\
.34\end{array}$ & .29 & $\begin{array}{r}.87 \\
1.33 \\
1.21\end{array}$ & $\mathrm{NV}$ & 1.44 & --- & $\begin{array}{r}.15 \\
1.24 \\
.43\end{array}$ & $\mathrm{NV}$ & $\mathrm{NV}$ & .42 & .91 & $\mathrm{NV}$ & 1.27 & .97 \\
\hline
\end{tabular}

Water flows from places of high potential energy to places of low potential energy and tends to follow paths of least resistance. In doing so, water will suspend and dissolve and transport materials with which it comes in contact. In urbanized or other developed areas, these materials can include lawn fertilizer, solvents, animal excretions, pesticides, automotive lubricants, and sediment. Today (2000), as in 1905, the greatest potential for nonpoint-source water pollution is from the city of Prescott, from livestock-grazing areas in the drainage area of Granite Creek upstream from the reservation, and from sediment eroded from rock material and soils. In urban areas, where impervious surfaces such as buildings, streets, and parking lots are dominant, the effect of storm runoff on pollutant transport is greater than in nonurban areas because the runoff-to-rainfall ratio is significantly larger (figs. 5 and 6). Although increased urbanization in the area has increased the potential for transporting human-induced pollutants onto the reservation, it also may have had the effect of reducing incoming sediment load.

Potential point sources of contamination on the reservation include the landfill at the VA Medical Center, the abandoned Stone Container wood-treatment site, the EZ Transmix cement plant, and the Yavapai
Gaming Center (fig. 1). The wood-treatment site was placed on the USEPA's Comprehensive Environmental Response, Compensation and Liability Act (CERCLA) list on March 1, 1988. Contaminants from the wood-treatment site have been well documented, and a cleanup effort is in progress. A ground-water contamination study at a similar site in Pensacola, Florida (Franks, 1986), found evidence of a denser-than-water hydrocarbon contaminant phase that moved vertically downward until it intercepted an impermeable material, and an aqueous phase of watersoluble compounds that moved at the speed and in the direction of ground-water flow. Also, the study suggests that wood-treatment compounds are being removed from the aqueous phase through selective degradation by microbial activity and sorption onto aquifer sediments; however, because of its nearly 80 years of operation, natural restoration is expected to take hundreds of years after the source of contamination is removed. On the basis of these findings, the length of operation at the Slaughterhouse Gulch site, and a rate of ground-water movement of $0.04 \mathrm{ft} / \mathrm{d}$, natural restoration of the aquifer in and downgradient from the Slaughterhouse Gulch area may take as long as 200 years. 


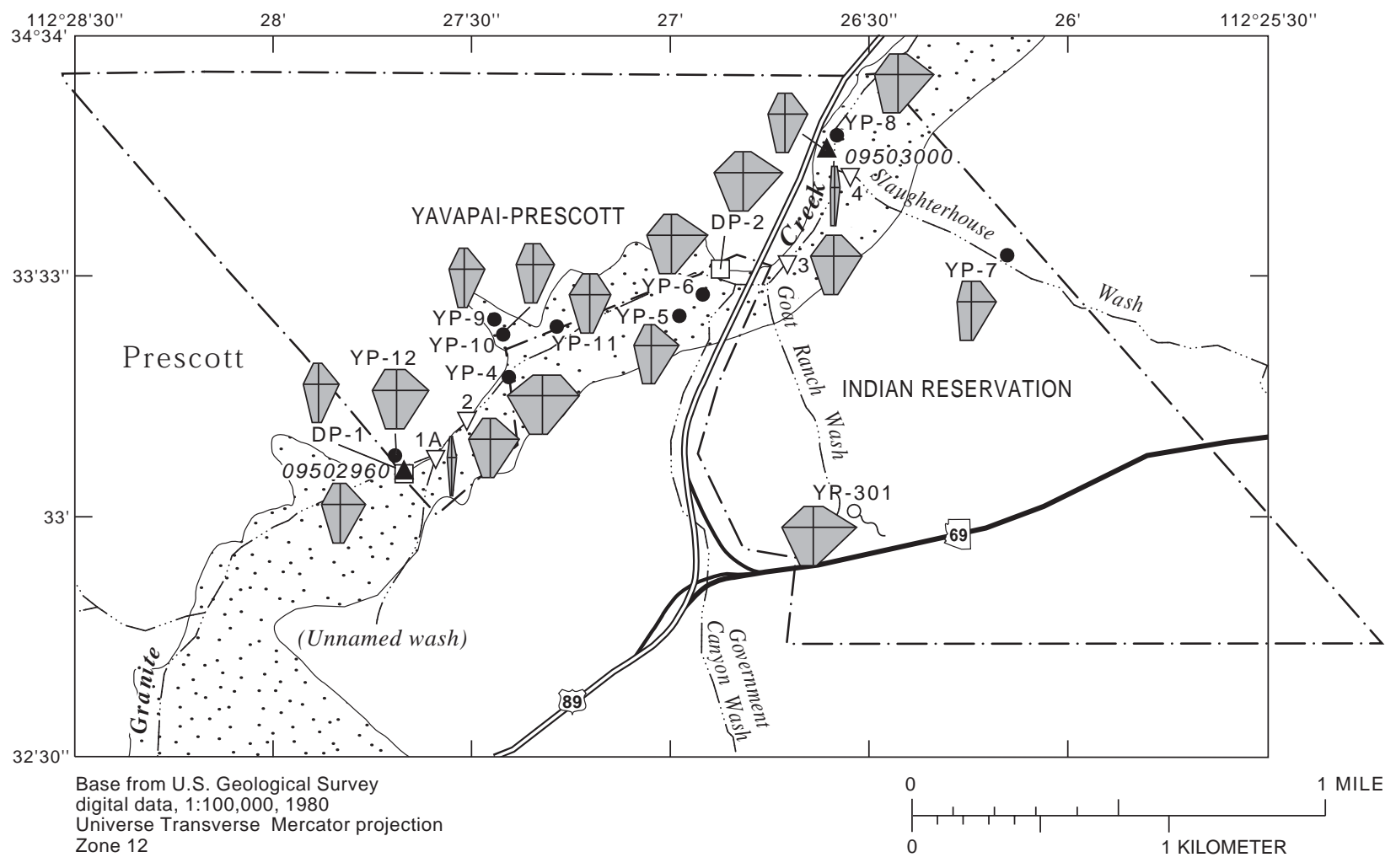

EXPLANATION
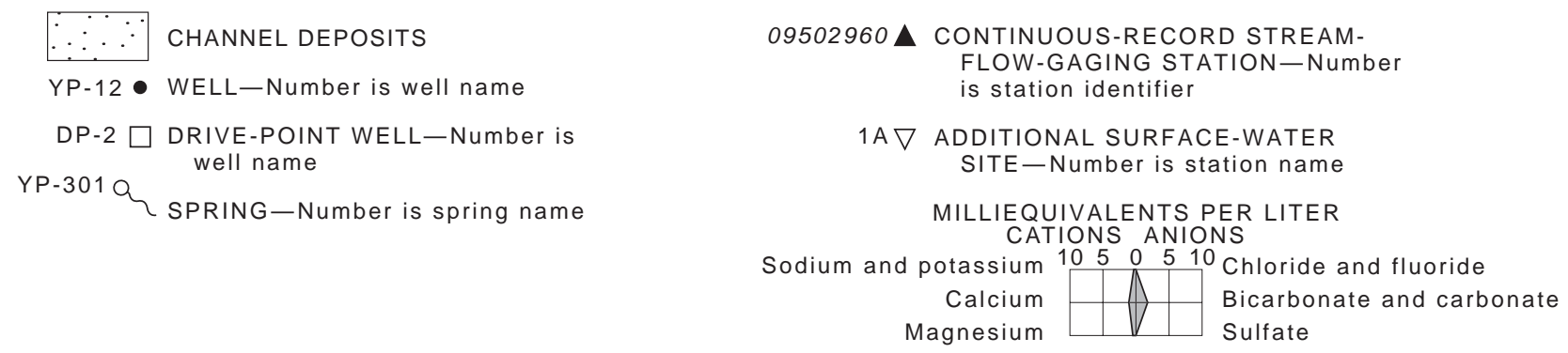

Figure 14. General chemistry of surface water and ground water, Yavapai-Prescott Indian Reservation, Arizona, 1994-98. 

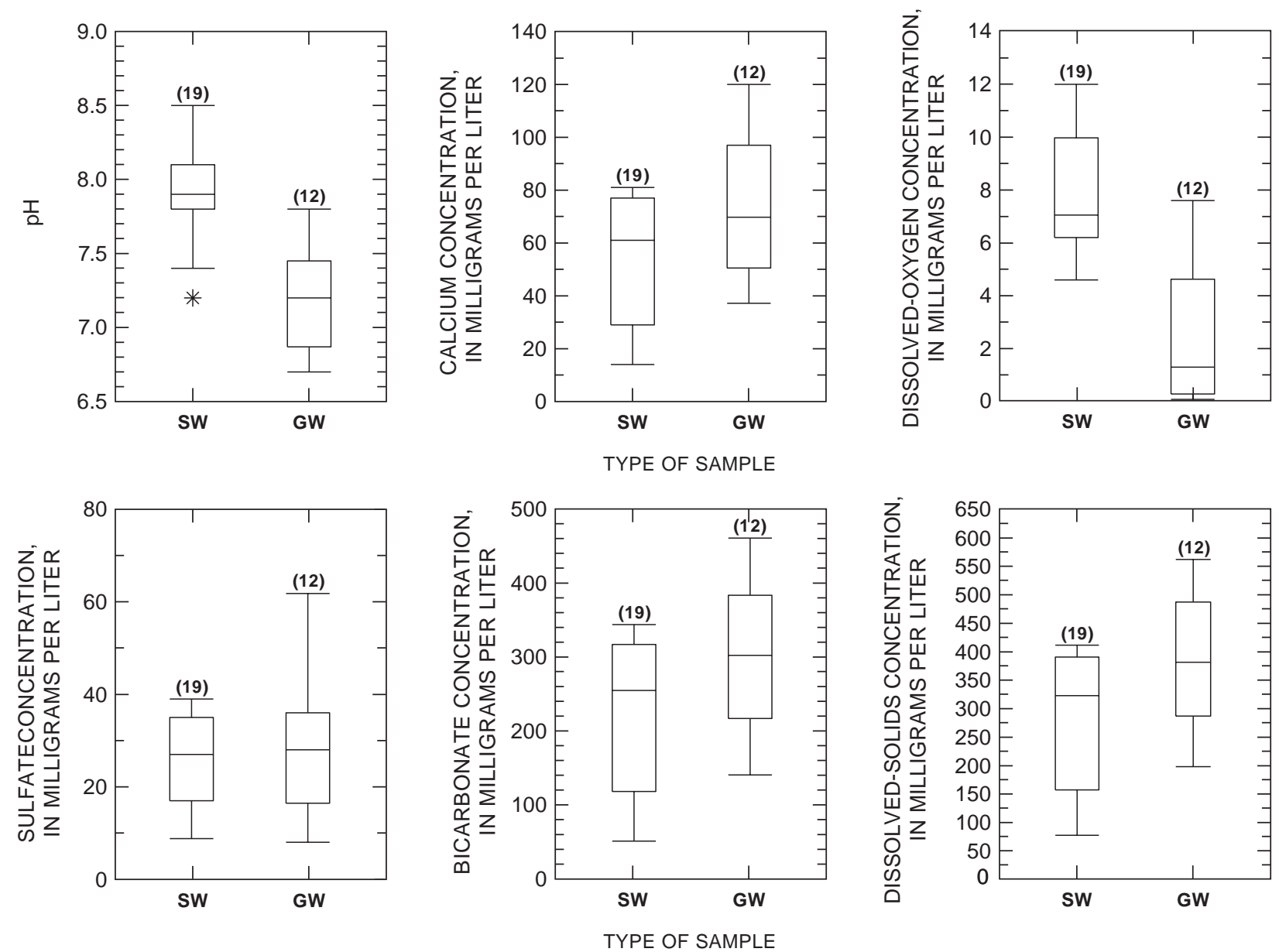

\section{EXPLANATION}

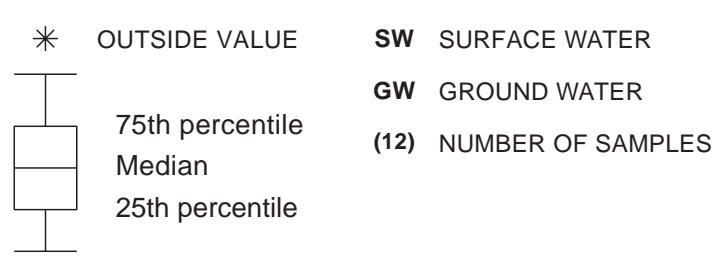

Figure 15. Comparison of $\mathrm{pH}$ and selected constituent concentrations in surface-water and ground-water samples, YavapaiPrescott Indian Reservation, Arizona, 1994-98. 
Active underground storage tanks are present on the reservation but are not known to be leaking (Woodward-Clyde Consultants, 1997). USEPA records further indicate that there were leaky underground storage tanks at EZ Transmix and at a site now occupied by the Yavapai Gaming Center (WoodwardClyde Consultants, 1997). Whether from point or nonpoint sources, contaminants along Granite Creek have the potential to affect the quality of recharge to the alluvial aquifer and, therefore, degrade the quality of ground water in the aquifer.

\section{SUMMARY}

Annual rainfall during this investigation averaged about $14.9 \mathrm{in}$. The total annual streamflow leaving the reservation along Granite Creek was about 430 acre-ft more than the amount of streamflow entering the reservation. The channel-fill and valley-fill sediments along the Granite Creek flood plain make up the principal aquifer. Ground-water supplies are only being developed for the containment of spring discharge for livestock and wildlife use. About 29 acre-ft of ground water leaves the reservation each year after discharging into Granite Creek. Most of the ground water that leaves the reservation each year does so during the winter months when evapotranspiration is lowest and the hydraulic head in the aquifer is higher than the stream channel. Water levels in wells throughout the reservation reflect seasonal variations in rainfall and snowmelt. Surface water and ground water on the reservation are calcium bicarbonate types. Fecal streptococcal and coliform bacteria in the surface water make it unsuitable for domestic use. Volatile and semivolatile organic compounds were detected in surface-water, streambed-sediment, and ground-water samples. The potential for contamination exists from point and nonpoint sources on and off the reservation. The greatest potential for nonpoint-source water contamination is from the city of Prescott, from livestock-grazing areas in the drainage area of Granite Creek upstream from the reservation, and from sediment eroded from rock material and soils. The potential point sources of contamination on the reservation include the landfill at the VA Medical Center, the abandoned Stone Container wood-treatment site, the EZ Transmix cement plant, and the Yavapai Gaming Center.

\section{SELECTED REFERENCES}

Agency for Toxic Substances and Disease Registry, 2000, Frequently Asked Questions About Contaminants Found at Hazardous Waste Sites: accessed February 14, 2000, at URL http://www.atsdr.cdc.gov/toxfaq.html/

Arizona Administrative Code, 1999, Title 18, Chapter 11, Water Quality Standards, R18-11-109, Numeric Water Quality Standards: accessed May 19, 1999, at URL http://www.sosaz.com/public_services/Title_18/1 8-11.htm.

Benson, M.A., and Dalrymple, Tate., 1967, General field and office procedures for indirect discharge measurements: U.S. Geological Survey Techniques of Water-Resources Investigations, book 3, chap. A1, $30 \mathrm{p}$.

Buchanan, T.J., and Somers, W.P., 1968, Stage measurement at gaging stations: U.S. Geological Survey Techniques of Water-Resources Investigations, book 3, chap. A7, $28 \mathrm{p}$.

1969, Discharge measurements at gaging stations: U.S. Geological Survey Techniques of Water-Resources Investigations, book 3, chapter A8, 65 p.

Driscoll, F.G., 1986, Groundwater and wells (2nd ed.): St. Paul, Minnesota, Johnson Division, 1,108 p.

Fenneman, N.M., 1931, Physiography of the western United States (1st ed.): New York and London, McGraw-Hill, $534 \mathrm{p}$.

Feth, J. H., 1965, Calcium, sodium, sulfate, and chloride in stream water of the western conterminous United States to 1957: U. S. Geological Survey Hydrologic-Investigations Atlas HA-189, 4 sheets, scale 1:2,500,000.

Fishman, M.J., and Friedman, L.C., eds., 1989, Methods for determination of inorganic substances in water and fluvial sediment: U.S. Geological Survey Techniques of Water-Resources Investigations, book 5, chap. A1, $545 \mathrm{p}$.

Franks, B.J., 1986, Distribution and movement of woodpreserving compounds in a surficial aquifer, Pensacola, Florida: in National Water Summary 1986Hydrologic events and ground-water quality, U.S. Geological Survey Water-Supply Paper 2325, p. 93-98.

Haeni, F.P., 1988, Application of seismic-refraction techniques to hydrologic studies: U.S. Geological Survey Techniques of Water-Resources Investigations, book 2, chap. D2, 86 p.

Heath, R.C., 1989, Basic ground-water hydrology: U.S. Geological Survey Water-Supply Paper 2220, 84 p.

Hem, J.D., 1988, Study and interpretation of the chemical characteristics of natural water ( $3 r d$ ed.): U.S. Geological Survey Water-Supply Paper 2254, 263 p. 
Johnson, T. E., 1977, An evaluation of alternate land use for the Granite Creek area, Yavapai-Prescott Reservation, Arizona: Office of Arid Lands Studies, University of Arizona, NADSAT Project Completion Report No. 6., p. 3-15.

Keys, W.S., 1990, Borehole geophysics applied to groundwater investigations: U.S. Geological Survey Techniques of Water-Resources Investigations, book 2, chap. E2, 150 p.

Koterba, M.T., Wilde, F.D., and Lapham, W.W., 1995, Ground-water data-collection protocols and procedures for the National Water-Quality Assessment program collection and documentation of water-quality samples and related data: U.S. Geological Survey Open-File Report 95-399, 113 p.

Krieger, M.H., 1965, Geology of the Prescott and Paulden quadrangles, Arizona: U.S. Geological Survey Professional Paper 467, 127 p.

Kuroda, P. K., and Sandell, E.B., 1953, Chlorine in igneous rocks: Geological Society of America Bulletin, v. 64, p. 879-896.

Lapham, W.W., Wilde, F. D., and Koterba, M. T., 1995, Ground-water data-collection protocols and procedures for the National Water-Quality Assessment program selection, installation, and documentation of wells, and collection of related data: U.S. Geological Survey Open-File Report 95-398, 69 p.

Morris, D.A., and Johnson, A.I., 1967, Summary of hydrologic and physical properties of rock and soil materials, as analyzed by the Hydrologic Laboratory of the U.S. Geological Survey, 1948-60: U.S. Geological Survey Water-Supply Paper 1839-D, 42 p.

National Oceanographic and Atmospheric Administration, 1933-97, Climatological data annual summary, Arizona, 1898-1997: Ashville, North Carolina, National Climate Data Center, v. 1-101, no. 13, published annually.

Percious, D.J., Boyer, D.G., and Norvelle, M.E., 1978, Water resources assessment of the Yavapai-Prescott Indian Reservation, Arizona: Office of Arid Lands Studies, University of Arizona, NADSAT Project Completion Report No. 12., 95 p.

Piper, A.M., 1944, A graphic procedure in the geochemical interpretation of water analysis: American Geophysical Union Transactions, v. 25, p. 914-923.

Rantz, S.E., and others, 1982a, Measurement and computation of stage: U.S. Geological Survey WaterSupply Paper 2175, p. 1-284. $1982 \mathrm{~b}$, Measurement and computation of streamflowVolume 2. Computation of discharge: U.S. Geological Survey Water-Supply Paper 2175, p. 285-631.

Rimrock Geophysics, Inc., 1995, Seismic Interpretation Program (SIP), commercially available software.
Sellers, W.D., Hill, R.D., and Sanderson-Rae, Margaret, eds., 1985, Arizona climate-The first hundred years: Tucson, Arizona, University of Arizona Press, 143 p.

Shelton, L.R., 1994, Field guide for collecting and processing stream-water samples for the National Water-Quality Assessment Program: U.S. Geological Survey Open-File Report 94-455, 42 p.

Shelton, L.R., and Capel, P.D., 1994, Guidelines for collecting and processing samples of streambed sediment for analysis of trace elements and organic contaminants for the National Water-Quality Assessment program: U.S. Geological Survey OpenFile Report 94-458, 20 p.

Shuter, E., and Teasdale, W.E., 1989, Application of drilling, coring, and sampling techniques to test holes and wells: U.S. Geological Survey Techniques of Water-Resources Investigations, book 2, chap. F1, 97 p.

Smith, C.F., Duet, N.R., Fisk, G.G., McCormack, H.F., Partin, C.K., Pope, G.L., Rigas, P.D., and Tadayon, Saeid, 1996, Water resources data for Arizona, water year 1995: U.S. Geological Survey Water-Data Report AZ-95-1, 306 p.

Southwest Ground-water Consultants, Inc., 1994, Phase II site characterization report: Prescott, Arizona, Southwest Ground-water Consultants, Inc., unpublished report.

Southwest Water and Mineral Resources, 1993a, Test hole drilling project plan for groundwater investigation of the Yavapai-Prescott Indian Reservation, Yavapai County, Arizona: Phoenix, AZ, Southwest Water and Mineral Resources, unpublished report. 1993b, Yavapai-Prescott Indian Tribe pre-development wells, summary of well construction and hydrogeological data: Phoenix, Arizona, Southwest Water and Mineral Resources, unpublished report.

Stallman, R.W., 1971, Aquifer-test design, observation, and data analysis: U.S. Geological Survey Techniques of Water Resources Investigations, book 3, chap. B1, 26 p.

Stiff, H.A., Jr., 1951, The interpretation of chemical water analysis by means of patterns: Journal of Petroleum Technology, v. 3, no. 10, p. 15-17.

Tukey, J.W., 1977, Exploratory data analysis: AddisonWesley Pub., Reading, Massachusetts, 506 p.

U.S. Department of Agriculture, 1989, Aerial reconnaissance of the Prescott National Forest and vicinity, Arizona: aerial photos, line 789, frames 180 184.

U.S. Environmental Protection Agency, 1988, Toxic chemicals fact sheet, benzene, in Open Data Solutions, Inc.: accessed October 1998 at URL http://mail.odsnet.com/TRIFacts/193.html. 1989, Toxic chemicals fact sheet, xylenes: in Open Data Solutions, Inc: accessed October 1998 at URL http://mail.odsnet.com/TRIFacts/86.html. 
1999, Laws and Regulations: accessed May 19, 1999, at URL http:// www.epa.gov/epahome/cfr40toc.htm. 2000, Office of Ground Water and Drinking Water, Proposed Revision to Arsenic Drinking Water Standard, accessed June 27, 2000, at URL http://www.epa.gov/ safewater/ars/proposalfs.html.

U.S. Geological Survey, 1954, Compilation of records of surface waters of the United States through September 1950, Part 9, Colorado River basin: U.S. Geological Survey Water-Supply Paper 1313, 749 p.

U.S. House of Representatives, 1935, Act of June 7, 1935 (49 Stat. 332): Washington, D.C., National Archives, 2 p.

1994, Yavapai-Prescott Indian Tribe Water Rights Settlement Act of 1994 (S. 1146/Public Law 103-433), in Congressional Record Index, History of Bills, v. 140,
Government Printing Office: accessed November 1998 at URL http://www.access.gpo.gov/congress/ index.html.

Winter, T.C., 1981, Uncertainties in estimating the water balance of lakes: American Water Resources Association, Water Resources Bulletin, v. 17, no. 1, p. 82-115.

Woodward-Clyde Consultants, 1997, Yavapai-Prescott Indian Tribe underground tank assessment and action plan: Phoenix, Arizona, Woodward-Clyde Consultants, unpublished report.

Yount, C.E.M.D., 1939, Notes on the history of the City of Prescott water supply: Sharlot Hall Museum, unpublished document. 
Table 8. Discharge data, Granite Creek at Prescott (09502960), Arizona, water year 1995

[---, no data; max, maximum; min, minimum]

DISCHARGE, IN CUBIC FEET PER SECOND, WATER YEAR 1995

DAILY MEAN VALUES

\begin{tabular}{|c|c|c|c|c|c|c|c|c|c|c|c|c|}
\hline Day & Oct. & Nov. & Dec. & Jan. & Feb. & Mar. & Apr. & May & Jun. & Jul. & Aug & Sep. \\
\hline 1 & --- & --- & 0.44 & 0.94 & 25 & ${ }^{1} 40$ & 5.5 & 3.1 & 0.38 & ${ }^{1} 0.40$ & 0.07 & 0.04 \\
\hline 2 & --- & --- & .44 & .86 & 38 & $1_{30}$ & 4.8 & 2.8 & .38 & .23 & .05 & .03 \\
\hline 3 & --- & --- & .43 & .78 & 42 & $1_{25}$ & 4.6 & 2.4 & .36 & .16 & .02 & .02 \\
\hline 4 & --- & --- & .43 & 13 & 31 & ${ }^{1} 25$ & 4.4 & 2.1 & .32 & .14 & .00 & .01 \\
\hline 5 & --- & --- & 1.9 & 201 & 25 & ${ }^{1} 130$ & 4.2 & 2.3 & .27 & .11 & .00 & .00 \\
\hline 6 & --- & --- & 7.2 & 39 & 20 & ${ }^{1} 940$ & 3.3 & 2.5 & .20 & .09 & .00 & ${ }^{1} 1.5$ \\
\hline 7 & --- & --- & .76 & 19 & 17 & ${ }^{1} 180$ & 2.9 & 2.5 & ${ }^{1} .20$ & .07 & .00 & .12 \\
\hline 8 & --- & --- & .59 & 14 & 15 & ${ }^{1} 100$ & 2.8 & 1.9 & ${ }^{1} .20$ & .07 & ${ }^{1} 2.0$ & ${ }^{1} 5.0$ \\
\hline 9 & --- & --- & .52 & 14 & 13 & 61 & 2.7 & 1.9 & ${ }^{1} .20$ & .03 & ${ }^{1} .30$ & .18 \\
\hline 10 & --- & --- & .47 & 13 & 12 & 42 & 2.6 & 1.7 & ${ }^{1} .20$ & .01 & ${ }^{1} .10$ & ${ }^{1} 10$ \\
\hline 11 & --- & --- & .47 & 46 & 10 & 173 & 2.5 & 1.6 & ${ }^{1} .20$ & .00 & ${ }^{1} .07$ & .44 \\
\hline 12 & --- & --- & .43 & 74 & 9.2 & 134 & 2.5 & 1.4 & ${ }^{1} .20$ & .00 & .05 & .14 \\
\hline 13 & --- & --- & .43 & 37 & 12 & 84 & 2.4 & 1.4 & ${ }^{1} .25$ & ${ }^{1} 4.0$ & .04 & .10 \\
\hline 14 & --- & --- & .43 & 24 & 620 & 59 & 2.4 & 1.2 & .21 & ${ }^{1} .20$ & .03 & .09 \\
\hline 15 & --- & --- & .43 & 18 & 918 & 43 & 2.4 & 1.1 & .18 & .17 & .08 & .08 \\
\hline 16 & --- & 0.42 & .43 & 16 & 178 & 33 & 5.1 & 8.5 & .21 & .11 & .06 & ${ }^{1} 5.0$ \\
\hline 17 & --- & .45 & .42 & 13 & 92 & 27 & 6.9 & 4.4 & .46 & .11 & .03 & .17 \\
\hline 18 & --- & .86 & ${ }^{1} .40$ & 9.6 & ${ }^{1} 60$ & 23 & 6.0 & 2.1 & .24 & .07 & .00 & .09 \\
\hline 19 & --- & .53 & ${ }^{1} .40$ & 8.2 & ${ }^{1} 40$ & 19 & 7.8 & 1.5 & .19 & .07 & .00 & .07 \\
\hline 20 & --- & .44 & ${ }^{1} .40$ & 7.3 & ${ }^{1} 30$ & 17 & 7.7 & 1.3 & .18 & .04 & ${ }^{1} 1.0$ & .06 \\
\hline 21 & --- & .43 & .39 & 6.7 & $1_{25}$ & 14 & 6.4 & 1.1 & .16 & .02 & ${ }^{1} 7.0$ & .06 \\
\hline 22 & --- & .43 & .39 & 5.7 & $1_{30}$ & 12 & 5.9 & .92 & .15 & .00 & .06 & .06 \\
\hline 23 & --- & .43 & 2.3 & 5.1 & ${ }^{1} 30$ & 13 & 6.2 & ${ }^{1} .70$ & .14 & .00 & ${ }^{1} 10$ & .05 \\
\hline 24 & --- & .43 & .71 & 4.7 & $1_{20}$ & 15 & 6.5 & ${ }^{1} .70$ & .13 & .00 & ${ }^{1} 1.5$ & .06 \\
\hline 25 & -- & .43 & 5.7 & 17 & $1_{20}$ & 11 & 6.1 & ${ }^{1} .60$ & .12 & .00 & ${ }^{1} 5.0$ & .06 \\
\hline 26 & --- & .52 & 11 & 82 & ${ }^{1} 17$ & 9.7 & 5.3 & .74 & .11 & .00 & .13 & .06 \\
\hline 27 & --- & .48 & 1.6 & 56 & $1_{20}$ & 8.9 & 4.7 & .65 & .11 & .00 & .07 & ${ }^{1} 10$ \\
\hline 28 & --- & .46 & 1.1 & 37 & $1_{25}$ & 7.8 & 4.1 & .77 & .10 & .00 & .06 & ${ }^{1} 60$ \\
\hline 29 & --- & .43 & 2.5 & 27 & --- & 7.2 & 3.7 & .65 & ${ }^{1} .30$ & .00 & .06 & 1.1 \\
\hline 30 & -- & .43 & 2.0 & 22 & --- & 6.8 & 3.3 & .49 & .20 & ${ }^{1} 1.0$ & .05 & .64 \\
\hline 31 & --- & --- & 1.1 & 20 & --- & 6.3 & --- & .42 & --- & .32 & .06 & --- \\
\hline Total & --- & --- & 46.21 & 851.88 & $2,394.2$ & $2,296.7$ & 135.7 & 55.44 & 6.55 & 7.42 & 27.89 & 95.23 \\
\hline Mean & --- & --- & 1.49 & 27.5 & 85.5 & 74.1 & 4.52 & 1.79 & .22 & .24 & .90 & 3.17 \\
\hline Max & --- & --- & 11 & 201 & 918 & 940 & 7.8 & 8.5 & .46 & 4.0 & 10 & 60 \\
\hline Min & --- & --- & .39 & .78 & 9.2 & 6.3 & 2.4 & .42 & .10 & .00 & .00 & .00 \\
\hline Acre-ft & --- & --- & 92 & 1,690 & 4,750 & 4,560 & 269 & 110 & 13 & 15 & 55 & 189 \\
\hline \multicolumn{2}{|c|}{ Water year 1995} & & Total --- & & Mean --- & & Maximum & & Minimum & --- & Acre-ft --- & \\
\hline
\end{tabular}


Table 9. Discharge data, Granite Creek at Prescott (09502960), Arizona, water year 1996

[---, no data; max, maximum; min, minimum]

\begin{tabular}{|c|c|c|c|c|c|c|c|c|c|c|c|c|}
\hline \multicolumn{13}{|c|}{$\begin{array}{l}\text { DISCHARGE, IN CUBIC FEET PER SECOND, WATER YEAR } 1996 \\
\text { DAILY MEAN VALUES }\end{array}$} \\
\hline Day & Oct. & Nov. & Dec. & Jan. & Feb. & Mar. & Apr. & May & Jun. & Jul. & Aug & Sep. \\
\hline 1 & 0.48 & 0.52 & 0.21 & 0.21 & 0.75 & 0.83 & ${ }^{1} 0.50$ & 0.07 & 0.00 & 0.00 & 0.30 & ${ }^{1} 0.00$ \\
\hline 2 & .30 & .10 & .20 & .21 & .11 & .81 & .52 & .07 & .00 & .00 & .22 & ${ }^{1} .00$ \\
\hline 3 & .16 & .09 & .20 & .21 & .10 & .75 & .47 & .07 & .00 & .51 & .12 & ${ }^{1} .50$ \\
\hline 4 & .09 & .09 & .21 & .21 & .10 & .73 & .45 & .07 & .00 & .00 & .10 & .27 \\
\hline 5 & .09 & .09 & .21 & .20 & .10 & .70 & .40 & .07 & .00 & .00 & .09 & 92 \\
\hline 6 & .09 & .11 & .21 & .19 & .10 & .60 & .39 & .06 & .00 & .00 & .08 & 26 \\
\hline 7 & .09 & .10 & .21 & .19 & .10 & .60 & .35 & .06 & .00 & .00 & .07 & 17 \\
\hline 8 & .09 & .09 & .21 & .19 & .10 & .60 & .31 & .06 & .00 & .00 & .07 & 6.5 \\
\hline 9 & .09 & .10 & .21 & .19 & .10 & .60 & .29 & .06 & .00 & 36 & .09 & 1.6 \\
\hline 10 & .09 & .10 & .21 & .19 & .10 & .59 & .33 & .06 & .00 & 28 & .09 & .62 \\
\hline 11 & .09 & .10 & .23 & ${ }^{1} .20$ & .10 & .60 & .27 & .05 & .00 & 1.5 & .05 & .49 \\
\hline 12 & .09 & .10 & .24 & ${ }^{1} .20$ & .11 & .62 & .27 & .05 & .00 & 1.4 & .04 & .26 \\
\hline 13 & .09 & .10 & .22 & ${ }^{1} .20$ & .10 & 4.7 & .27 & .03 & .00 & .33 & .04 & 19 \\
\hline 14 & .09 & .12 & .21 & ${ }^{1} .20$ & .10 & 1.5 & .25 & .02 & .07 & .18 & .05 & 2.9 \\
\hline 15 & .09 & .13 & .21 & .19 & .10 & .84 & .24 & .02 & ${ }^{1} .00$ & 39 & .08 & .64 \\
\hline 16 & .09 & .12 & .26 & .19 & .10 & .73 & .24 & .01 & ${ }^{1} .00$ & 2.3 & .03 & .27 \\
\hline 17 & .09 & .12 & .24 & .20 & .10 & .63 & .23 & .00 & ${ }^{1} .00$ & .51 & .02 & .22 \\
\hline 18 & .09 & .10 & .21 & .21 & .10 & .60 & .21 & .00 & ${ }^{1} .00$ & .26 & .02 & .14 \\
\hline 19 & .10 & .12 & .21 & .21 & .11 & .60 & .19 & .00 & .00 & .19 & .01 & .11 \\
\hline 20 & .10 & .14 & .21 & .21 & .14 & .58 & .17 & .00 & .00 & .15 & .01 & .08 \\
\hline 21 & .09 & .14 & .21 & .21 & .13 & .59 & .16 & .00 & .00 & .12 & .01 & .07 \\
\hline 22 & .09 & .14 & .21 & .24 & 3.7 & .60 & .16 & .00 & .00 & .09 & .01 & .07 \\
\hline 23 & .09 & .14 & .21 & .27 & .45 & .56 & .14 & .00 & .00 & .07 & .01 & .07 \\
\hline 24 & .12 & .14 & .21 & .24 & .39 & .55 & .14 & .00 & .00 & .05 & .01 & .06 \\
\hline 25 & ${ }^{1} .10$ & .14 & .21 & .21 & 1.0 & .63 & .12 & .00 & .00 & .19 & .01 & .06 \\
\hline 26 & ${ }^{1} .10$ & .16 & .21 & .21 & 3.6 & .53 & .12 & .00 & .00 & 32 & .01 & .06 \\
\hline 27 & ${ }^{1} .10$ & .19 & .21 & .21 & 3.3 & .55 & .10 & .00 & .00 & 5.4 & 6.9 & .06 \\
\hline 28 & ${ }^{1} .10$ & .20 & .21 & .21 & 1.1 & .59 & .09 & .00 & .00 & 33 & .26 & .06 \\
\hline 29 & .10 & .21 & .21 & .21 & .91 & ${ }^{1} 1.0$ & .09 & .00 & .00 & .69 & .03 & .06 \\
\hline 30 & .10 & .21 & .21 & .21 & --- & ${ }^{1} .50$ & .08 & .00 & .00 & .34 & .01 & .06 \\
\hline 31 & .10 & --- & .21 & .24 & --- & ${ }^{1} .50$ & --- & .00 & --- & .28 & .00 & --- \\
\hline Total & 3.58 & 4.21 & 6.63 & 6.46 & 17.30 & 24.81 & 7.55 & 0.83 & 0.07 & 182.56 & 8.84 & 169.23 \\
\hline Mean & .12 & .14 & .21 & .21 & .60 & .80 & .25 & .027 & .002 & 5.89 & .29 & 5.64 \\
\hline Max & .48 & .52 & .26 & .27 & 3.7 & 4.7 & .52 & .07 & .07 & 39 & 6.9 & 92 \\
\hline Min & .09 & .09 & .20 & .19 & .10 & .50 & .08 & .00 & .00 & .00 & .00 & .00 \\
\hline Acre-ft & 7.1 & 8.4 & 13 & 13 & 34 & 49 & 15 & 1.6 & .1 & 362 & 18 & 336 \\
\hline \multicolumn{2}{|c|}{ Water year 1996} & & Total 432 & & Mean 1.18 & & Maximun & & Minimum & 0.00 & Acre-ft 857 & \\
\hline
\end{tabular}


Table 10. Discharge data, Granite Creek at Prescott (09502960), Arizona, water year 1997

[---, no data; max, maximum; min, minimum]

DISCHARGE, IN CUBIC FEET PER SECOND, WATER YEAR 1997 DAILY MEAN VALUES

\begin{tabular}{|c|c|c|c|c|c|c|c|c|c|c|c|c|}
\hline Day & Oct. & Nov. & Dec. & Jan. & Feb. & Mar. & Apr. & May & Jun. & Jul. & Aug & Sep. \\
\hline 1 & 0.06 & 0.05 & 0.07 & 0.10 & 9.1 & 6.0 & 1.2 & 0.30 & 0.05 & ${ }^{1} 0.00$ & 0.00 & 6.5 \\
\hline 2 & .07 & .05 & .07 & .10 & 8.2 & 7.6 & 4.3 & .21 & .05 & ${ }^{1} .00$ & .00 & .44 \\
\hline 3 & .07 & .05 & .07 & 2.0 & 7.5 & 12 & 16 & .20 & .04 & ${ }^{1} .00$ & 1.8 & 2.9 \\
\hline 4 & .07 & .05 & .07 & .15 & ${ }^{1} 5.5$ & 13 & 8.3 & .19 & .04 & ${ }^{1} .00$ & 4.8 & .38 \\
\hline 5 & .07 & .05 & .07 & .11 & ${ }^{1} 5.0$ & 12 & 7.4 & .17 & .04 & ${ }^{1} .00$ & .13 & 3.2 \\
\hline 6 & .07 & .06 & .07 & .12 & ${ }^{1} 5.0$ & 13 & 7.0 & .16 & .06 & ${ }^{1} .00$ & .10 & 4.4 \\
\hline 7 & .07 & .06 & .07 & .11 & 2.8 & 15 & 7.0 & .14 & .06 & ${ }^{1} .00$ & .08 & .13 \\
\hline 8 & .06 & .06 & .07 & .11 & 2.6 & 17 & 8.2 & .14 & .07 & .00 & .37 & 2.8 \\
\hline 9 & .06 & .06 & .07 & .10 & 2.3 & 17 & 8.2 & .13 & .06 & .00 & .77 & .41 \\
\hline 10 & .06 & .06 & 8.1 & .10 & 2.0 & 16 & 6.8 & .13 & .05 & .00 & .11 & .12 \\
\hline 11 & .06 & .07 & .11 & .11 & 1.9 & 14 & 5.9 & .46 & .04 & .00 & .09 & 7.1 \\
\hline 12 & .06 & .07 & .09 & 4.2 & 1.7 & 12 & 4.5 & .16 & .04 & .00 & .08 & .39 \\
\hline 13 & .06 & .07 & .08 & 15 & 2.2 & 10 & 3.9 & .12 & .04 & .00 & .06 & .12 \\
\hline 14 & .07 & .08 & .08 & 4.7 & 1.5 & 8.1 & 3.2 & .11 & .04 & .00 & 6.9 & .10 \\
\hline 15 & .03 & .10 & .08 & 1.4 & 1.4 & 6.9 & 3.0 & .10 & .06 & .00 & .25 & 1.7 \\
\hline 16 & .03 & .11 & .08 & 1.7 & 1.4 & 5.9 & 2.4 & .10 & .06 & .00 & .04 & .15 \\
\hline 17 & .03 & .11 & .08 & 1.5 & 1.3 & 5.0 & 2.1 & .10 & .05 & .00 & .03 & .10 \\
\hline 18 & .04 & ${ }^{1} .11$ & .09 & 1.2 & 1.2 & 3.9 & 2.0 & .10 & .04 & .00 & .02 & .09 \\
\hline 19 & .04 & ${ }^{1} .11$ & .08 & 1.3 & 1.2 & 3.6 & 1.8 & .09 & .01 & .00 & .02 & .08 \\
\hline 20 & .04 & ${ }^{1} .11$ & .08 & 2.4 & 1.2 & 3.2 & 1.6 & 1.0 & ${ }^{1} .00$ & .00 & .02 & .07 \\
\hline 21 & .05 & .11 & .09 & 2.0 & 1.1 & 2.7 & 1.4 & .12 & ${ }^{1} .00$ & .00 & .04 & .07 \\
\hline 22 & .05 & 4.6 & .09 & 1.5 & 1.0 & 2.4 & 1.3 & .09 & ${ }^{1} .00$ & .00 & .30 & .07 \\
\hline 23 & .06 & .09 & .09 & 1.6 & .98 & 2.2 & ${ }^{1} 1.1$ & .07 & ${ }^{1} .00$ & .00 & 4.8 & .07 \\
\hline 24 & .05 & .07 & .10 & 2.2 & 1.1 & 2.1 & ${ }^{1} .90$ & .07 & ${ }^{1} .00$ & .00 & .11 & .07 \\
\hline 25 & .06 & .07 & .09 & 2.7 & 1.1 & 1.8 & 1.82 & .07 & ${ }^{1} .00$ & .00 & 2.6 & 16 \\
\hline 26 & .07 & .09 & .10 & 69 & 1.0 & 1.7 & .82 & .07 & ${ }^{1} .00$ & .00 & .69 & 314 \\
\hline 27 & .07 & .07 & .09 & 63 & 3.5 & 1.6 & .77 & .07 & ${ }^{1} .00$ & .00 & .87 & 35 \\
\hline 28 & .06 & .07 & .09 & 27 & 12 & 1.5 & .60 & .07 & ${ }^{1} .00$ & .00 & .07 & 14 \\
\hline 29 & .06 & .09 & .09 & 18 & --- & 1.4 & .49 & .06 & ${ }^{1} .00$ & .00 & 1.5 & 6.7 \\
\hline 30 & .06 & .07 & .10 & 14 & --- & 1.3 & .40 & .05 & ${ }^{1} .00$ & .00 & 6.4 & 3.7 \\
\hline 31 & .91 & --- & .11 & 11 & --- & 1.2 & --- & .05 & --- & .00 & .63 & --- \\
\hline Total & 2.62 & 6.82 & 10.62 & 248.51 & 86.78 & 221.1 & 113.40 & 4.90 & 0.90 & 0.00 & 33.68 & 420.86 \\
\hline Mean & .085 & .23 & .34 & 8.02 & 3.10 & 7.13 & 3.78 & .16 & .030 & .00 & 1.09 & 14.0 \\
\hline Max & .91 & 4.6 & 8.1 & 69 & 12 & 17 & 16 & 1.0 & .07 & .00 & 6.9 & 314 \\
\hline Min & .03 & .05 & .07 & .10 & .98 & 1.2 & .40 & .05 & .00 & .00 & .00 & .07 \\
\hline Acre-ft & 5.2 & 14 & 21 & 493 & 172 & 439 & 225 & 9.7 & 1.8 & .00 & 67 & 835 \\
\hline \multicolumn{2}{|c|}{ Water year 1997} & \multicolumn{3}{|c|}{ Total 1150.2} & Mean 3.14 & & \multicolumn{2}{|c|}{ Maximum 314} & Minimum & \multicolumn{3}{|c|}{ Acre-ft 2,280} \\
\hline
\end{tabular}


Table 11. Discharge data, Granite Creek near Prescott (09503000), Arizona, water year 1995

[---, no data; max, maximum; min, minimum]

\begin{tabular}{|c|c|c|c|c|c|c|c|c|c|c|c|c|}
\hline \multicolumn{13}{|c|}{$\begin{array}{l}\text { DISCHARGE, IN CUBIC FEET PER SECOND, WATER YEAR } 1995 \\
\text { DAILY MEAN VALUES }\end{array}$} \\
\hline Day & Oct. & Nov. & Dec. & Jan. & Feb. & Mar. & Apr. & May & Jun. & Jul. & Aug & Sep. \\
\hline 1 & ${ }^{1} 0.20$ & 0.32 & 0.44 & ${ }^{1} 1.5$ & 27 & 43 & 6.5 & 3.9 & 0.57 & 0.54 & 0.13 & 0.17 \\
\hline 2 & ${ }^{1} .20$ & .38 & .44 & ${ }^{1} 1.5$ & 38 & 31 & 6.1 & 3.9 & .51 & .35 & .09 & .15 \\
\hline 3 & ${ }^{1} .20$ & .38 & .44 & ${ }^{1} 1.5$ & 43 & 26 & 5.8 & 3.5 & .51 & .23 & .07 & .13 \\
\hline 4 & ${ }^{1} .20$ & 1.1 & .66 & ${ }^{1} 15$ & 35 & 25 & 5.5 & 3.2 & .52 & .19 & .07 & .13 \\
\hline 5 & ${ }^{1} .20$ & .66 & 2.0 & ${ }^{1} 210$ & 28 & 131 & 5.1 & 3.1 & .51 & .17 & .05 & .13 \\
\hline 6 & ${ }^{1} .20$ & .51 & 12 & ${ }^{1} 40$ & 23 & 953 & 4.8 & 3.5 & .51 & .17 & .04 & 2.8 \\
\hline 7 & ${ }^{1} .20$ & .44 & 1.3 & 22 & 20 & 190 & 4.6 & 3.7 & .49 & .20 & .04 & 1.3 \\
\hline 8 & .17 & 1.0 & .90 & 16 & 18 & 102 & 4.3 & 3.2 & .44 & .19 & 2.7 & 14 \\
\hline 9 & .17 & .66 & .73 & 16 & 16 & 66 & 4.0 & 3.1 & .44 & .15 & .48 & 2.2 \\
\hline 10 & .13 & .51 & .66 & 14 & 14 & 45 & 3.9 & 2.8 & .49 & .15 & .14 & 16 \\
\hline 11 & .13 & .44 & .66 & 48 & 12 & 177 & 3.7 & 2.5 & .55 & .14 & .09 & 3.4 \\
\hline 12 & .13 & 11 & .59 & 77 & 11 & 145 & 3.6 & 2.0 & .49 & .13 & .08 & .96 \\
\hline 13 & .13 & 1.1 & .59 & 39 & 12 & 89 & 3.4 & 1.9 & .47 & 4.3 & .09 & .38 \\
\hline 14 & .13 & .73 & .59 & 26 & 617 & 61 & 3.3 & 1.8 & .46 & .42 & .09 & .25 \\
\hline 15 & 35 & .73 & .59 & 20 & 932 & 46 & 3.3 & 1.7 & .44 & .19 & 1.4 & .21 \\
\hline 16 & 2.6 & .80 & .51 & 18 & 185 & 36 & 6.9 & 11 & .42 & .17 & .14 & 12 \\
\hline 17 & 1.1 & .73 & .51 & 14 & 97 & 29 & 7.4 & 6.3 & .52 & .15 & .10 & 2.6 \\
\hline 18 & .66 & .80 & .51 & 11 & 61 & 24 & 5.9 & 2.9 & .55 & .13 & .09 & .82 \\
\hline 19 & .51 & .90 & .44 & 9.2 & 42 & 20 & 8.9 & 2.1 & .39 & .13 & .09 & .40 \\
\hline 20 & .44 & .51 & .44 & 8.5 & 32 & 18 & 10 & 1.6 & .38 & .12 & .14 & .28 \\
\hline 21 & .38 & .51 & .44 & 7.8 & 27 & 16 & 7.1 & 1.4 & .38 & .10 & 16 & .25 \\
\hline 22 & .38 & .51 & .51 & 6.8 & 31 & 13 & 6.0 & 1.1 & .33 & .08 & 1.3 & .21 \\
\hline 23 & .32 & .44 & 2.7 & 5.9 & 29 & 13 & 6.5 & .90 & .32 & .08 & 17 & .21 \\
\hline 24 & .38 & .51 & 1.5 & 5.5 & 21 & 15 & 7.1 & .90 & .32 & .08 & 5.8 & .20 \\
\hline 25 & .38 & .44 & 6.0 & 20 & 21 & 11 & 6.7 & .82 & .29 & .06 & 5.1 & .17 \\
\hline 26 & .32 & .44 & 20 & 86 & 18 & 10 & 6.0 & .80 & .27 & .04 & 1.2 & .17 \\
\hline 27 & .32 & .59 & 2.6 & 55 & 21 & 9.2 & 5.4 & .77 & .26 & .05 & .38 & 8.5 \\
\hline 28 & .32 & .44 & $1_{2.0}$ & 40 & 26 & 8.7 & 4.9 & .76 & .21 & .04 & .24 & 65 \\
\hline 29 & .32 & .44 & ${ }^{1} 2.5$ & 30 & --- & 7.7 & 4.3 & .97 & .23 & .04 & .20 & 2.2 \\
\hline 30 & .32 & .44 & ${ }^{1} 3.5$ & 25 & --- & 7.3 & 4.2 & .70 & .34 & 1.7 & .17 & 1.2 \\
\hline 31 & .32 & --- & ${ }^{1} 2.0$ & 23 & --- & 6.9 & --- & .66 & --- & .37 & .17 & --- \\
\hline Total & 46.46 & 28.46 & 68.75 & 913.2 & 2,457 & $2,374.8$ & 165.2 & 77.48 & 12.61 & 10.86 & 53.68 & 136.42 \\
\hline Mean & 1.50 & .95 & 2.22 & 29.5 & 87.8 & 76.6 & 5.51 & 2.5 & .42 & .35 & 1.73 & 4.55 \\
\hline Max & 35 & 11 & 20 & 210 & 932 & 953 & 10 & 11 & .57 & 4.3 & 17 & 65 \\
\hline Min & .13 & .32 & .44 & 1.5 & 11 & 6.9 & 3.3 & .66 & .21 & .04 & .04 & .13 \\
\hline Acre-ft & 92 & 56 & 136 & 1,810 & 4,870 & 4,710 & 328 & 154 & 25 & 22 & 106 & 271 \\
\hline \multicolumn{2}{|c|}{ Water year 1995} & \multicolumn{3}{|c|}{ Total 6,340 } & Mean & & \multicolumn{2}{|c|}{ Maximum 953} & Minimum & 0.04 & \multicolumn{2}{|c|}{ Acre-ft 12,580} \\
\hline
\end{tabular}

IEstimated. 
Table 12. Discharge data, Granite Creek near Prescott (09503000), Arizona, water year 1996

[---, no data; max, maximum; min, minimum]

DISCHARGE, IN CUBIC FEET PER SECOND, WATER YEAR 1996

DAILY MEAN VALUES

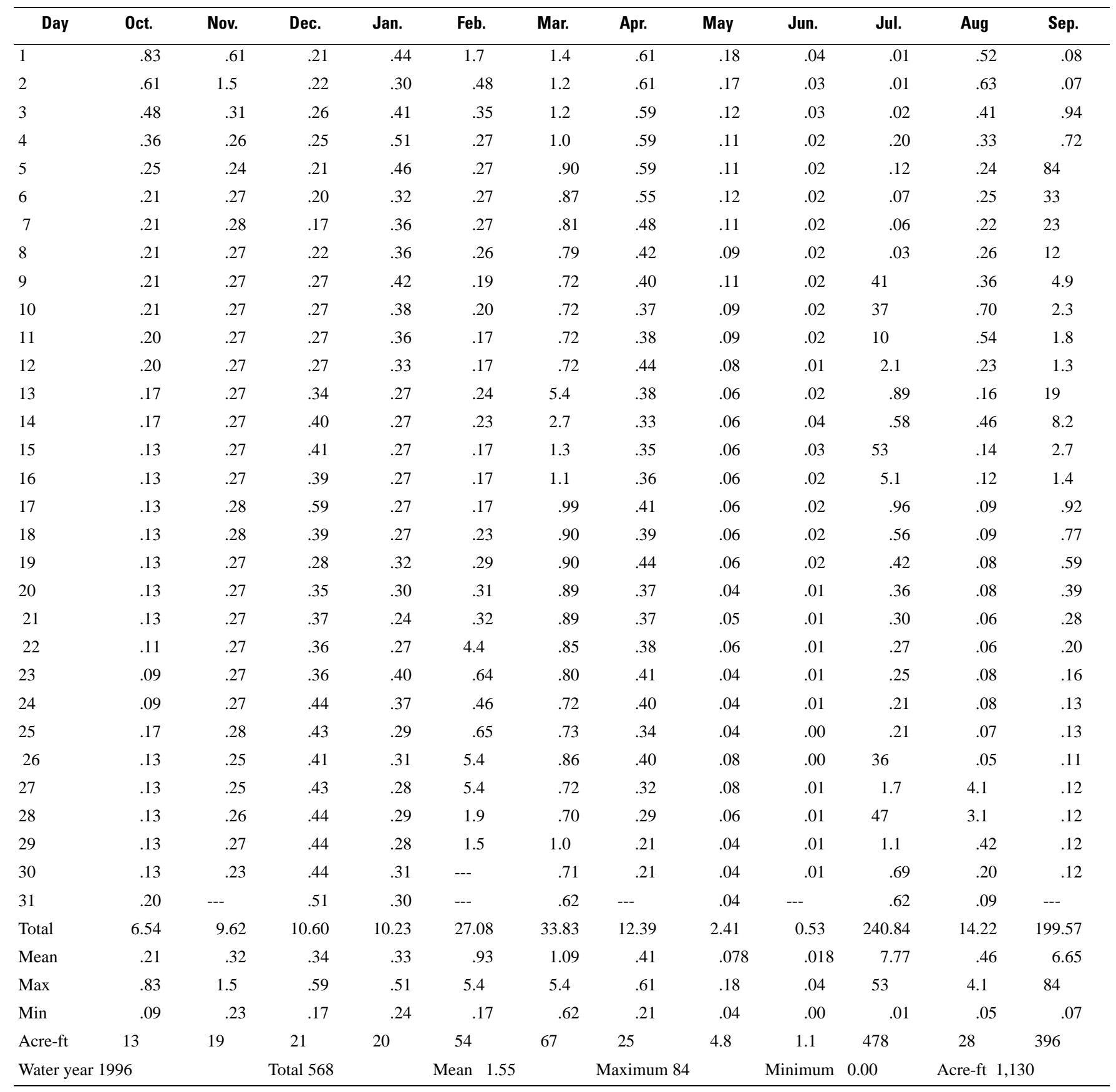


Table 13. Discharge data, Granite Creek near Prescott (09503000), Arizona, water year 1997

[---, no data; max, maximum; min, minimum]

\begin{tabular}{|c|c|c|c|c|c|c|c|c|c|c|c|c|}
\hline \multicolumn{13}{|c|}{$\begin{array}{l}\text { DISCHARGE, IN CUBIC FEET PER SECOND, WATER YEAR } 1997 \\
\text { DAILY MEAN VALUES }\end{array}$} \\
\hline Day & Oct. & Nov. & Dec. & Jan. & Feb. & Mar. & Apr. & May & Jun. & Jul. & Aug & Sep. \\
\hline 1 & 0.10 & 0.17 & 0.22 & 0.28 & 9.1 & 7.7 & 1.9 & 0.52 & 0.08 & 0.01 & 0.01 & 5.5 \\
\hline 2 & .09 & .13 & .22 & .27 & 8.2 & 8.4 & 4.3 & .47 & .08 & .01 & .01 & 1.3 \\
\hline 3 & .09 & .11 & .22 & 2.1 & 7.7 & 12 & 18 & .46 & .08 & .01 & .25 & 1.8 \\
\hline 4 & .08 & .09 & .22 & .49 & 6.6 & 13 & 10 & .41 & .08 & .01 & 6.1 & 1.0 \\
\hline 5 & .08 & .09 & .22 & .33 & 5.8 & 12 & 8.3 & .36 & .07 & .01 & .34 & .87 \\
\hline 6 & .08 & .09 & .22 & .34 & 4.8 & 12 & 8.3 & .34 & .09 & .01 & .18 & 7.0 \\
\hline 7 & .08 & .09 & .22 & .29 & 3.9 & 14 & 8.3 & .31 & .09 & .01 & .05 & .45 \\
\hline 8 & .08 & .09 & .22 & .28 & 3.8 & 15 & 9.0 & .28 & .09 & .01 & .04 & 3.3 \\
\hline 9 & .08 & .11 & .22 & .27 & 3.4 & 15 & 9.3 & .24 & .09 & .01 & .10 & 2.0 \\
\hline 10 & .08 & .13 & 9.5 & .29 & 2.9 & 14 & 8.5 & .24 & .07 & .01 & .06 & .37 \\
\hline 11 & .08 & .13 & .39 & .28 & 2.6 & 13 & 7.9 & .28 & .06 & .01 & .03 & 5.5 \\
\hline 12 & .08 & .13 & .30 & 1.9 & 2.3 & 11 & 6.5 & .45 & .06 & .01 & .02 & .92 \\
\hline 13 & .08 & .13 & .26 & 23 & 3.1 & 9.6 & 5.4 & .26 & .05 & .01 & .02 & .34 \\
\hline 14 & .10 & .17 & .26 & 7.9 & 2.0 & 8.4 & 4.4 & .21 & .05 & .01 & 9.7 & .27 \\
\hline 15 & .10 & .21 & .23 & 4.5 & 1.7 & 7.3 & 3.8 & .19 & .05 & .01 & 1.2 & .53 \\
\hline 16 & .10 & .22 & .23 & 3.2 & 1.4 & 6.6 & 2.8 & .17 & .06 & .01 & .21 & .53 \\
\hline 17 & .11 & .22 & .22 & 3.1 & 1.3 & 5.8 & 2.1 & .17 & .05 & .01 & .10 & .32 \\
\hline 18 & .10 & .22 & .22 & 2.6 & 1.2 & 5.3 & 1.9 & .17 & .04 & .01 & .07 & .23 \\
\hline 19 & .10 & .22 & .22 & 2.8 & 1.2 & 4.5 & 1.7 & .15 & .03 & .01 & .06 & .18 \\
\hline 20 & .11 & .22 & .22 & 4.2 & 1.2 & 4.3 & 1.4 & .37 & .03 & .01 & .06 & .16 \\
\hline 21 & .11 & .22 & .23 & 4.1 & 1.1 & 3.9 & 1.1 & .45 & .03 & .02 & .07 & .16 \\
\hline 22 & .11 & 5.2 & .22 & 3.4 & .95 & 3.7 & 1.0 & .29 & .03 & .02 & .07 & .16 \\
\hline 23 & .13 & .38 & .22 & 3.0 & .92 & 3.3 & .94 & .22 & .03 & .02 & 5.5 & .15 \\
\hline 24 & .14 & .26 & .22 & 4.2 & .91 & 3.0 & .89 & .20 & .02 & .01 & .50 & .15 \\
\hline 25 & .16 & .22 & .23 & 4.6 & 1.1 & 2.6 & .83 & .18 & .02 & .01 & .83 & 13 \\
\hline 26 & .13 & .25 & .23 & 65 & .94 & 2.5 & .81 & .17 & .02 & .01 & 2.4 & 296 \\
\hline 27 & .13 & .25 & .28 & 64 & 3.4 & 2.1 & .77 & .13 & .02 & .01 & .36 & 43 \\
\hline 28 & .11 & .25 & .25 & 24 & 13 & 2.0 & .67 & .10 & .02 & .01 & .37 & 20 \\
\hline 29 & .10 & .24 & .26 & 16 & --- & 1.9 & .59 & .09 & .02 & .01 & 1.6 & 12 \\
\hline 30 & .09 & .28 & .26 & 13 & --- & 1.8 & .56 & .09 & .01 & .02 & 6.9 & 8.0 \\
\hline 31 & .54 & --- & .27 & 10 & --- & 1.7 & --- & .08 & --- & .02 & 1.5 & --- \\
\hline Total & 3.55 & 10.55 & 16.68 & 269.72 & 96.52 & 227.4 & 131.96 & 8.05 & 1.52 & 0.36 & 38.71 & 425.19 \\
\hline Mean & .11 & .35 & .54 & 8.7 & 3.45 & 7.34 & 4.40 & .26 & .051 & .012 & 1.25 & 14.2 \\
\hline Max & .54 & 5.2 & 9.5 & 65 & 13 & 15 & 18 & .52 & .09 & .02 & 9.7 & 296 \\
\hline Min & .08 & .09 & .22 & .27 & .91 & 1.7 & .56 & .08 & .01 & .01 & .01 & .15 \\
\hline Acre-ft & 7.0 & 21 & 33 & 535 & 191 & 451 & 262 & 16 & 3.0 & .7 & 77 & 843 \\
\hline \multicolumn{2}{|c|}{ Water year 1997} & & Total 1,230 & & Mean 3.36 & & Maximum & & Minimum & 0.01 & Acre-ft & \\
\hline
\end{tabular}




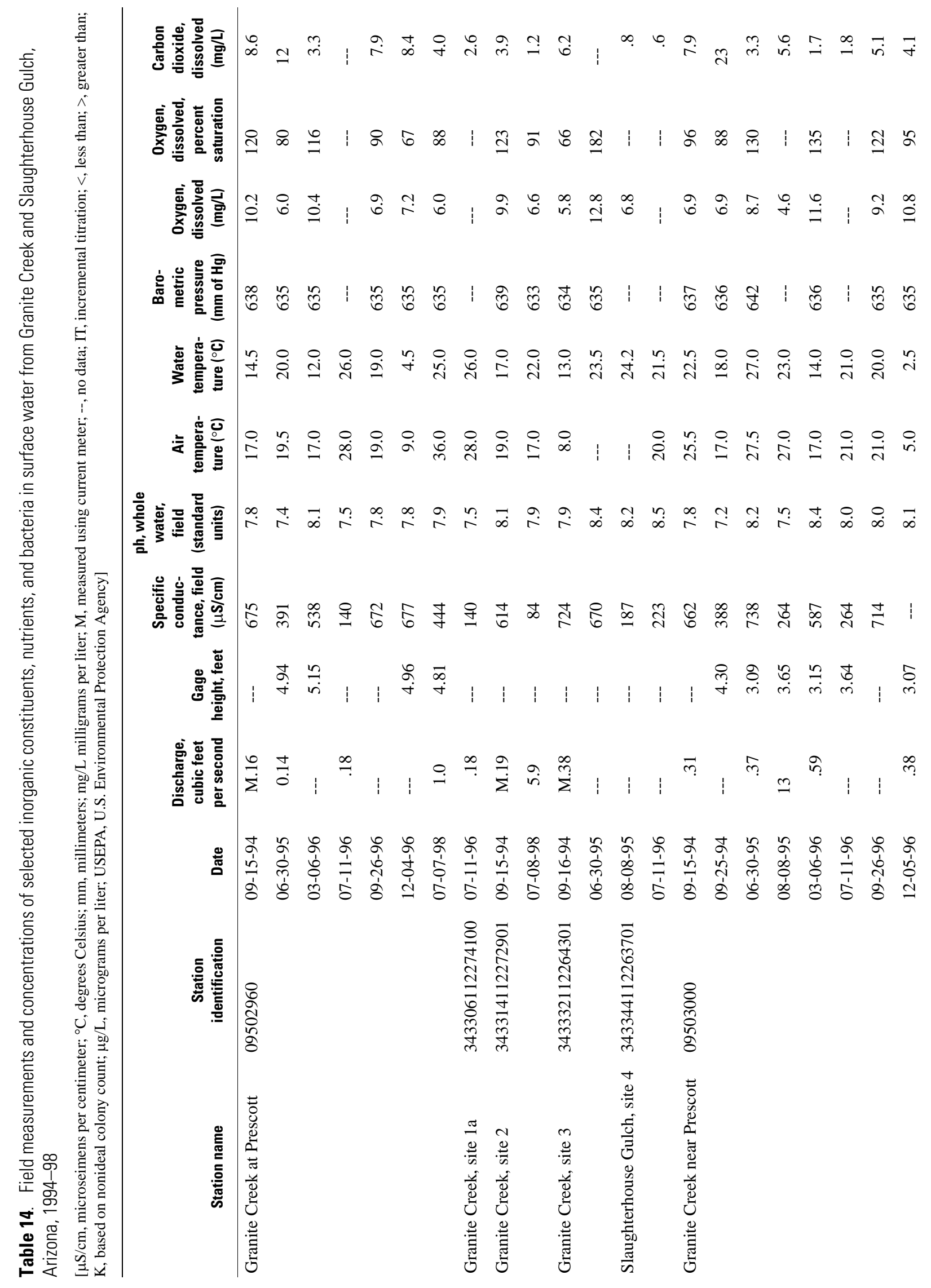




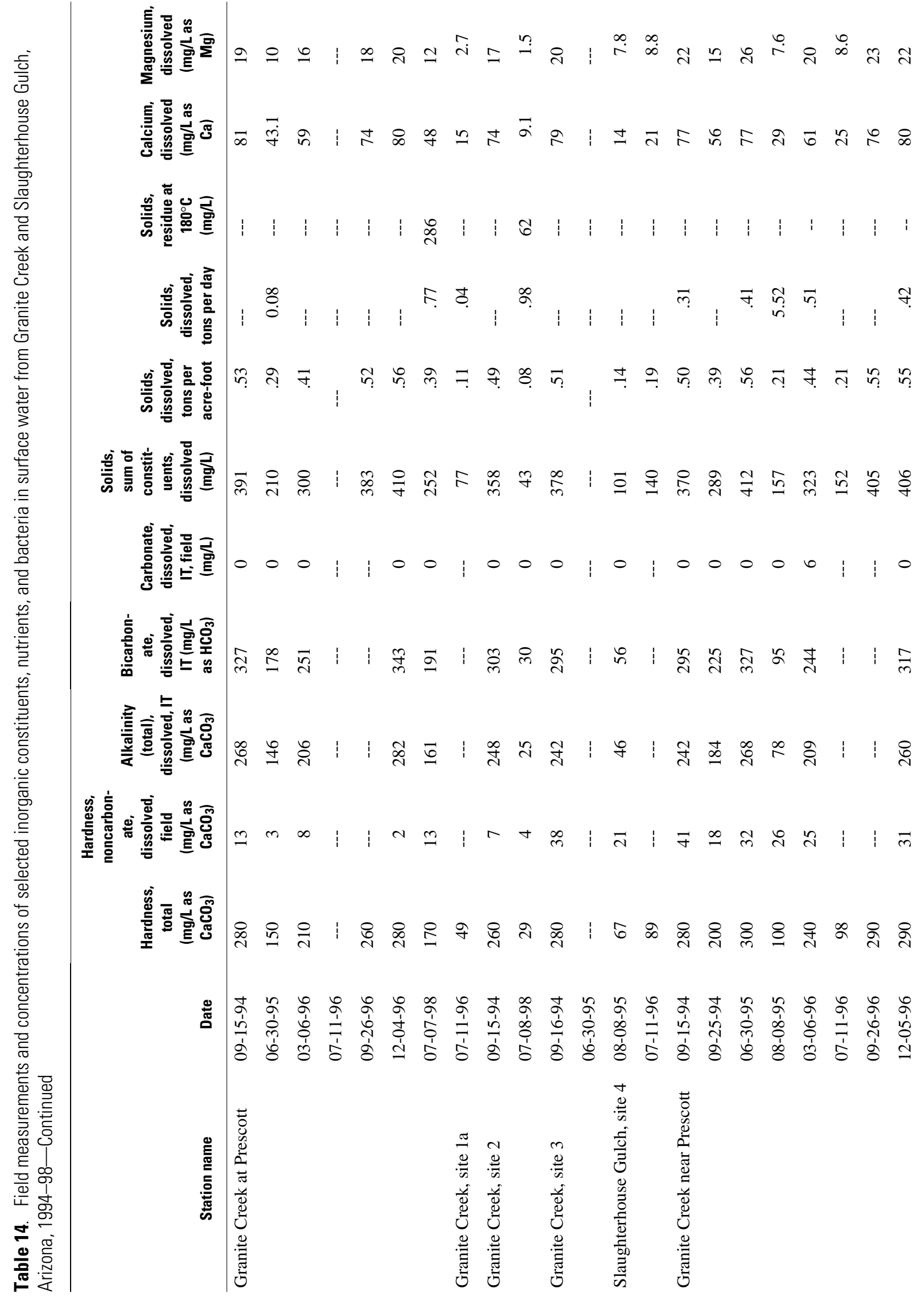




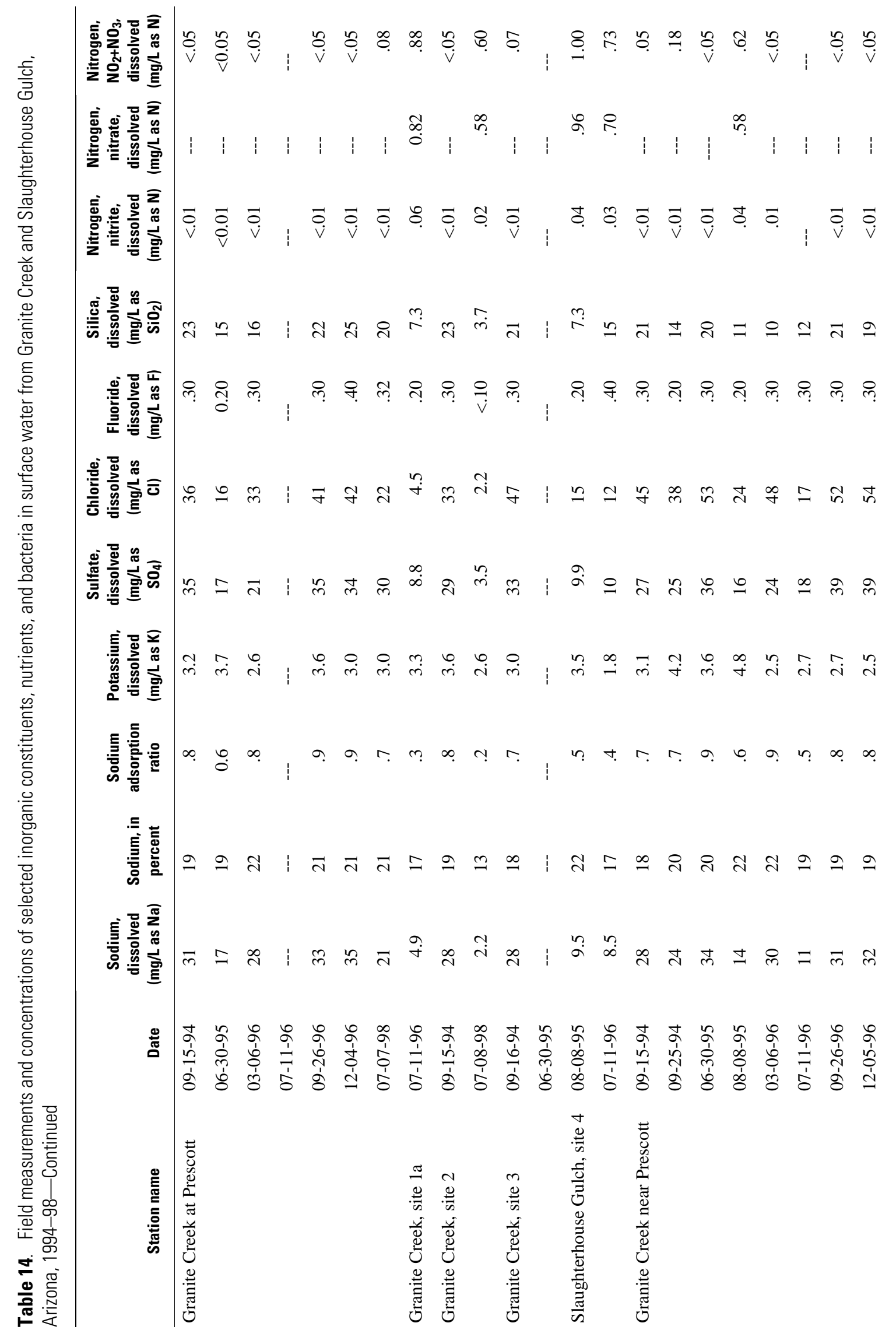




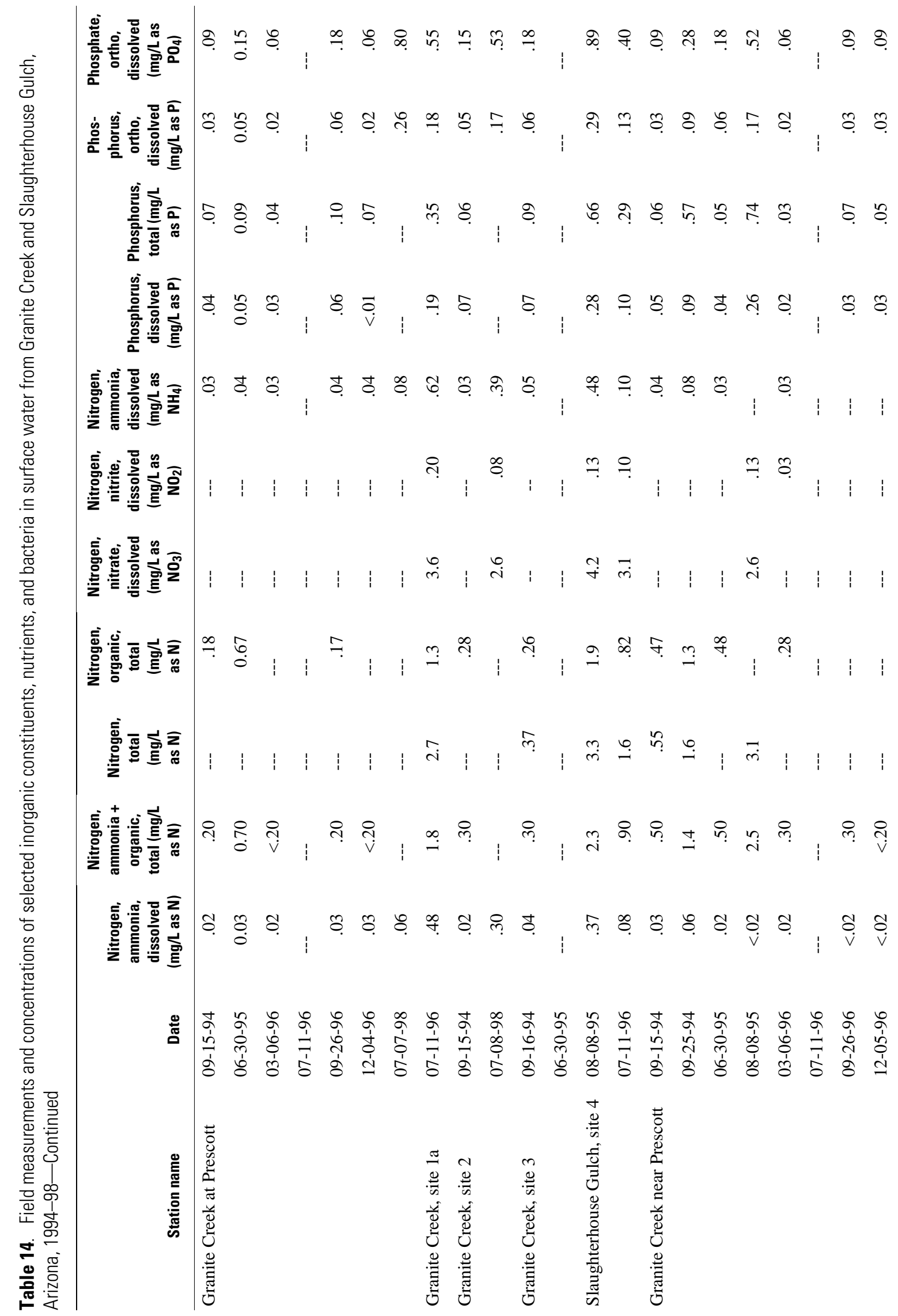




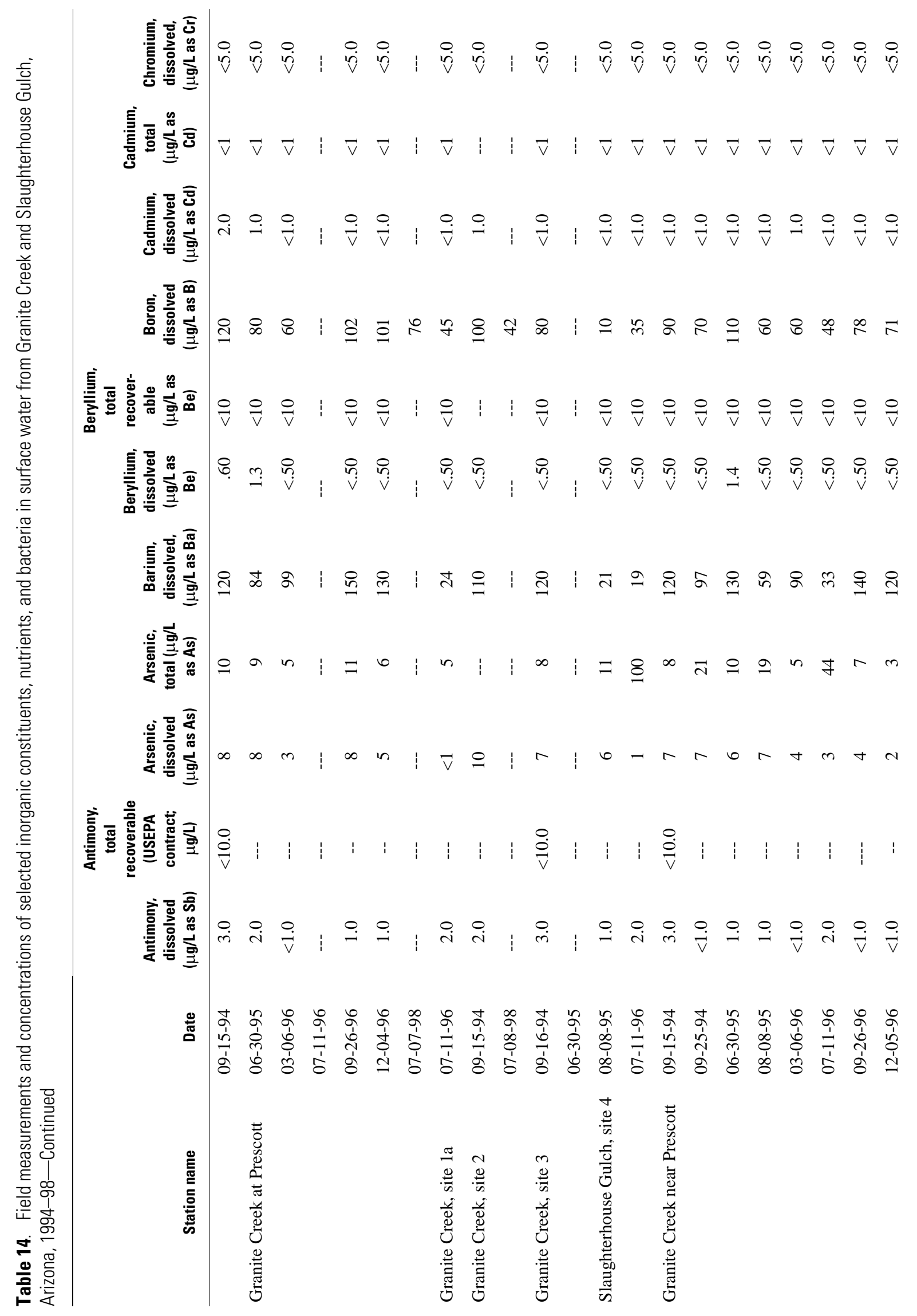




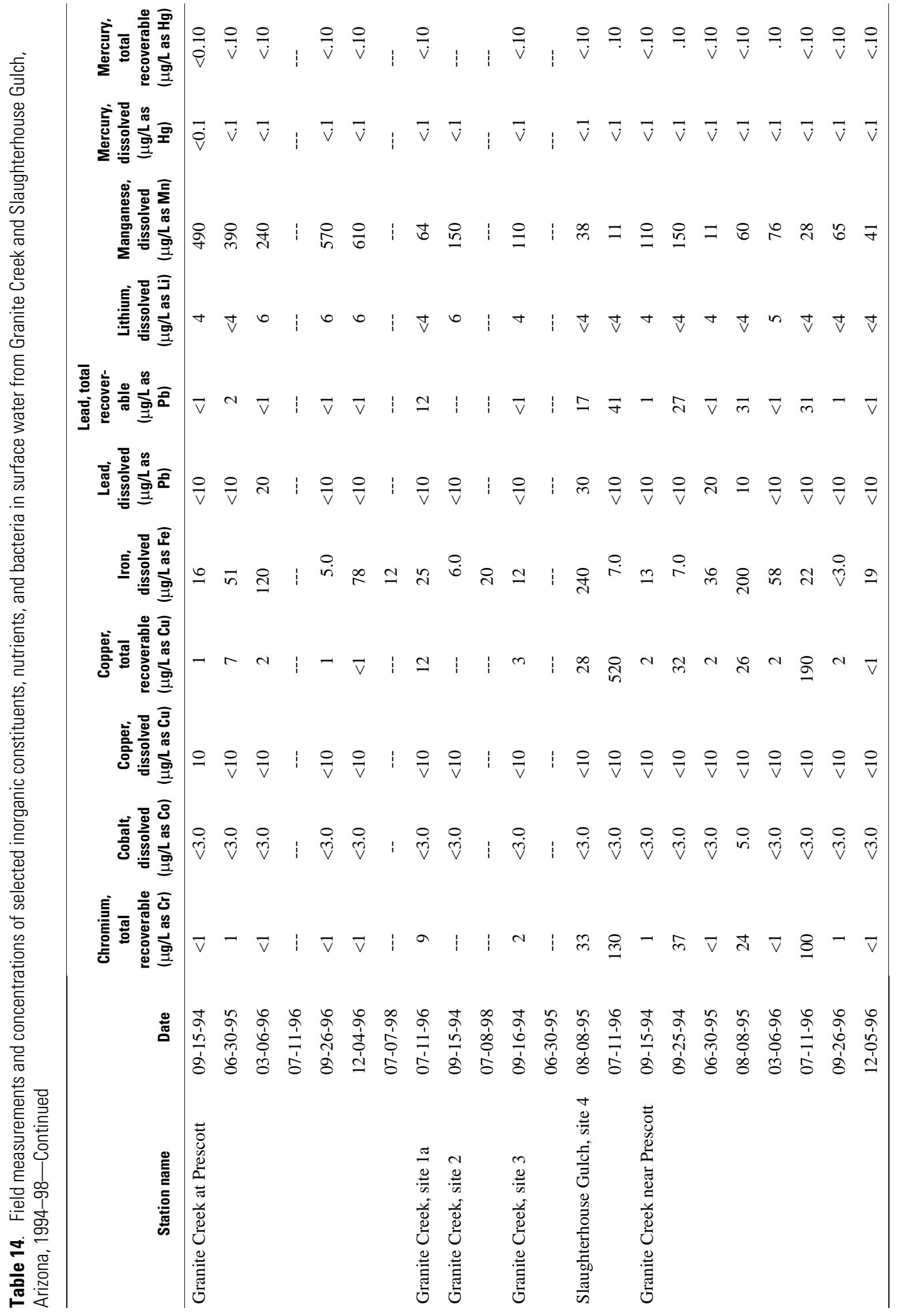




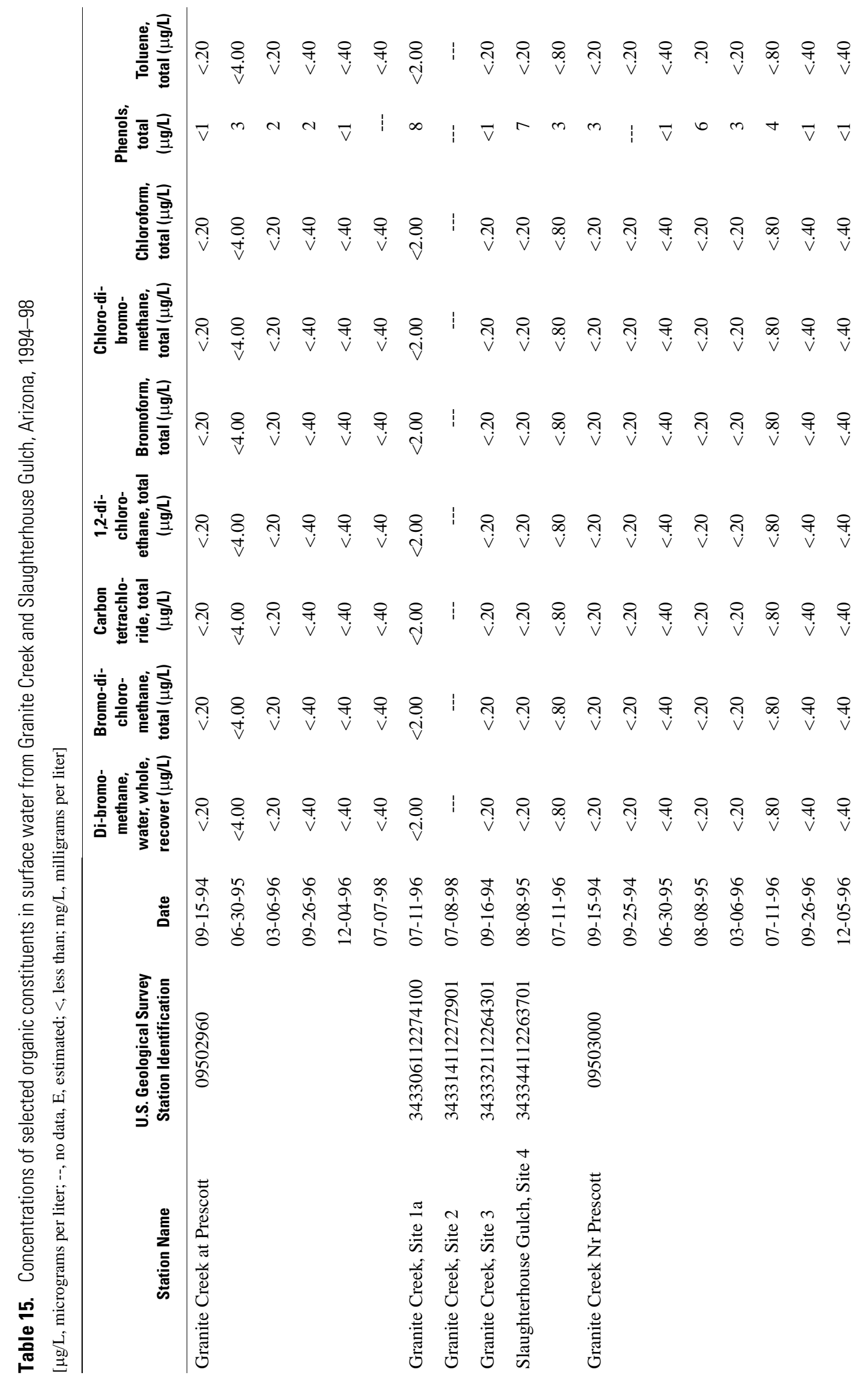




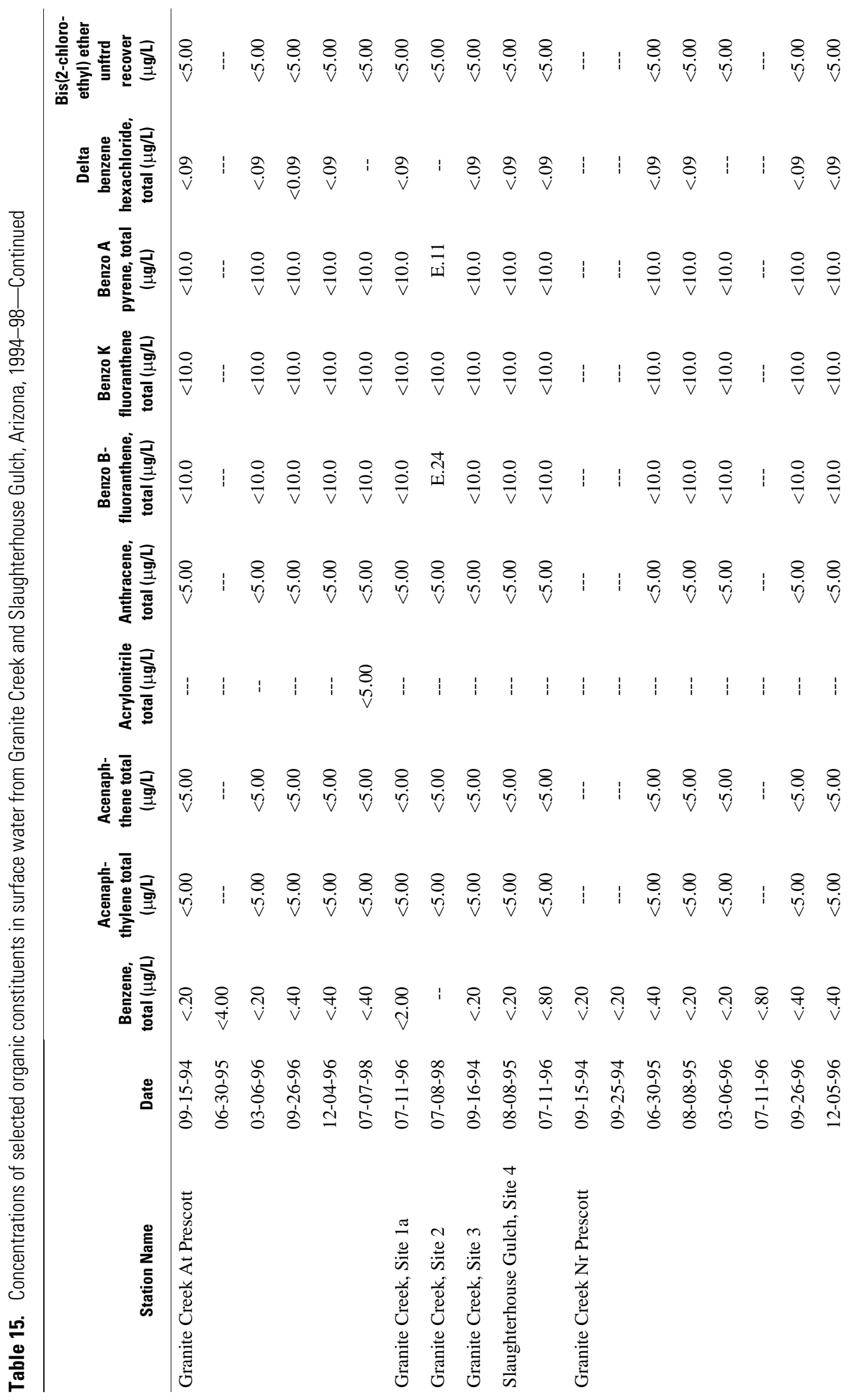




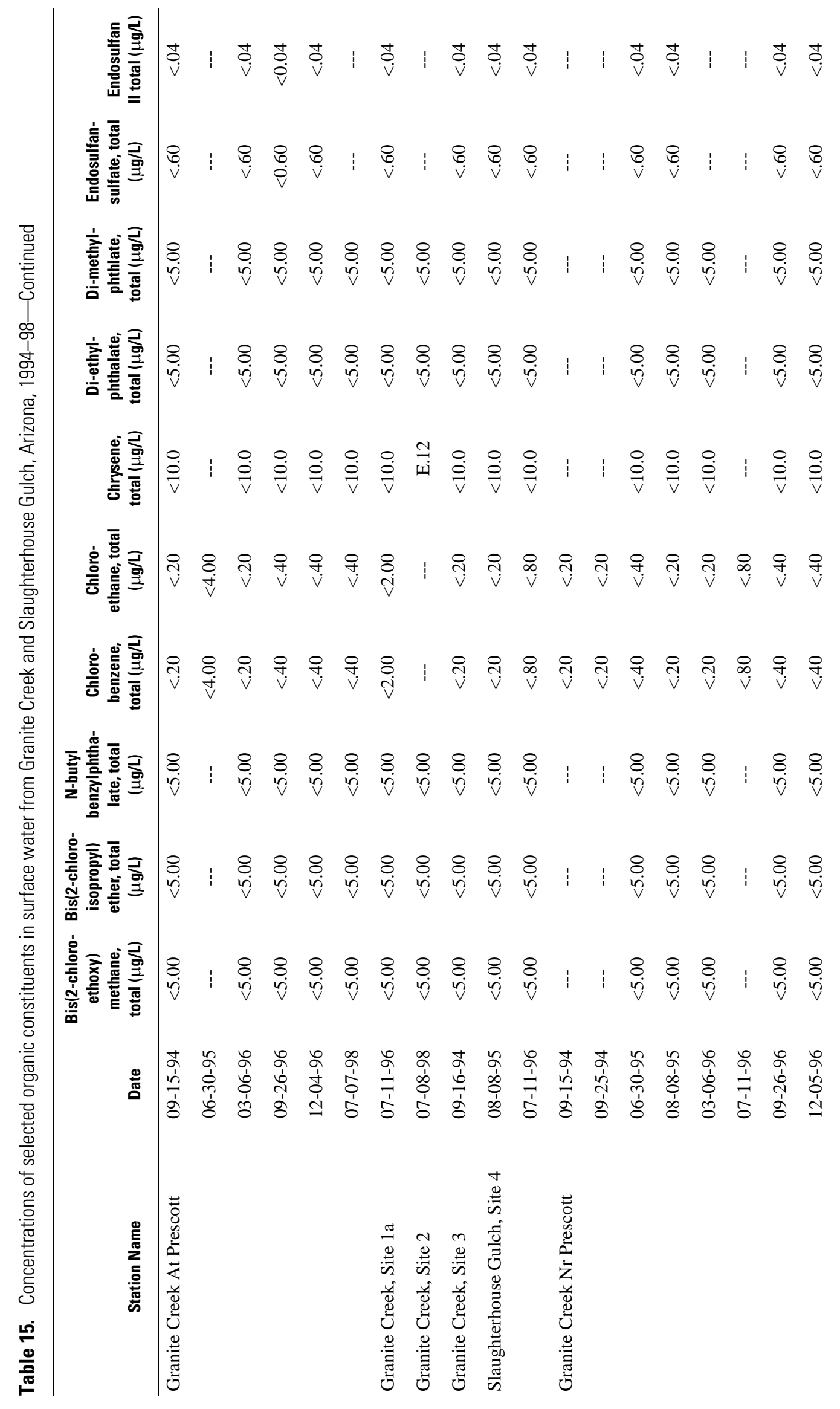




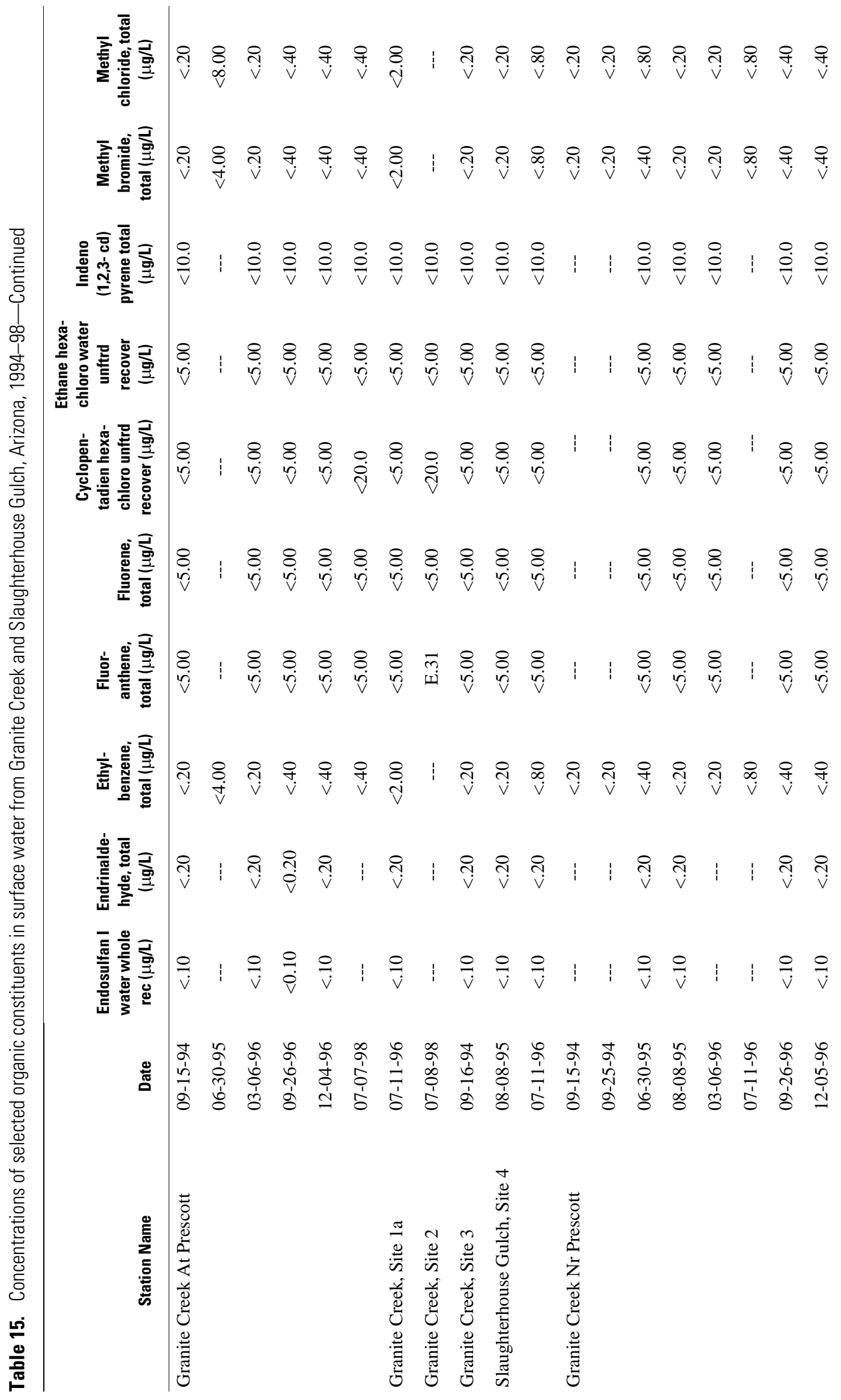

54 Occurrence and Quality of Surface Water and Ground Water within the Yapavai-Prescott Indian Reservation 


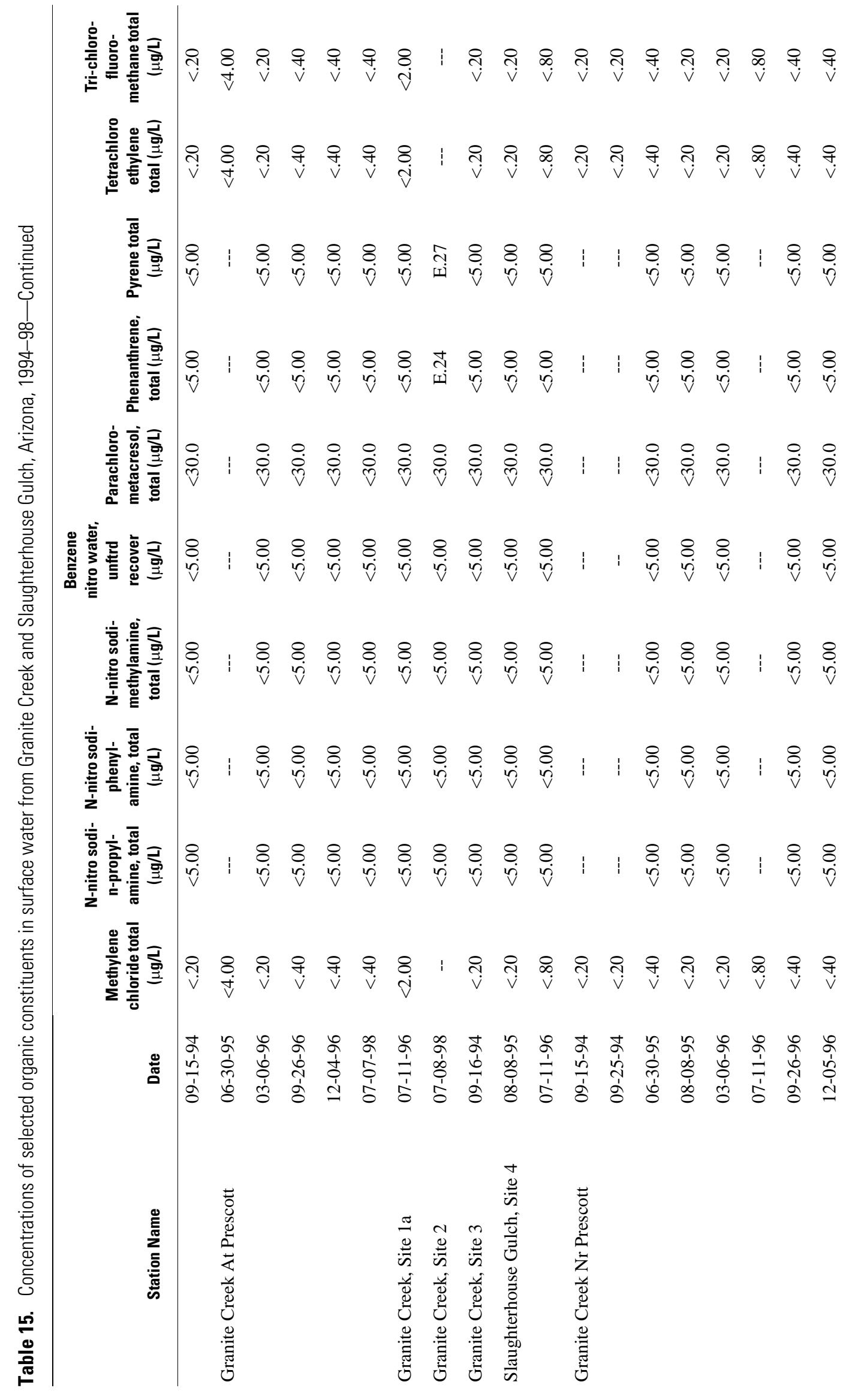




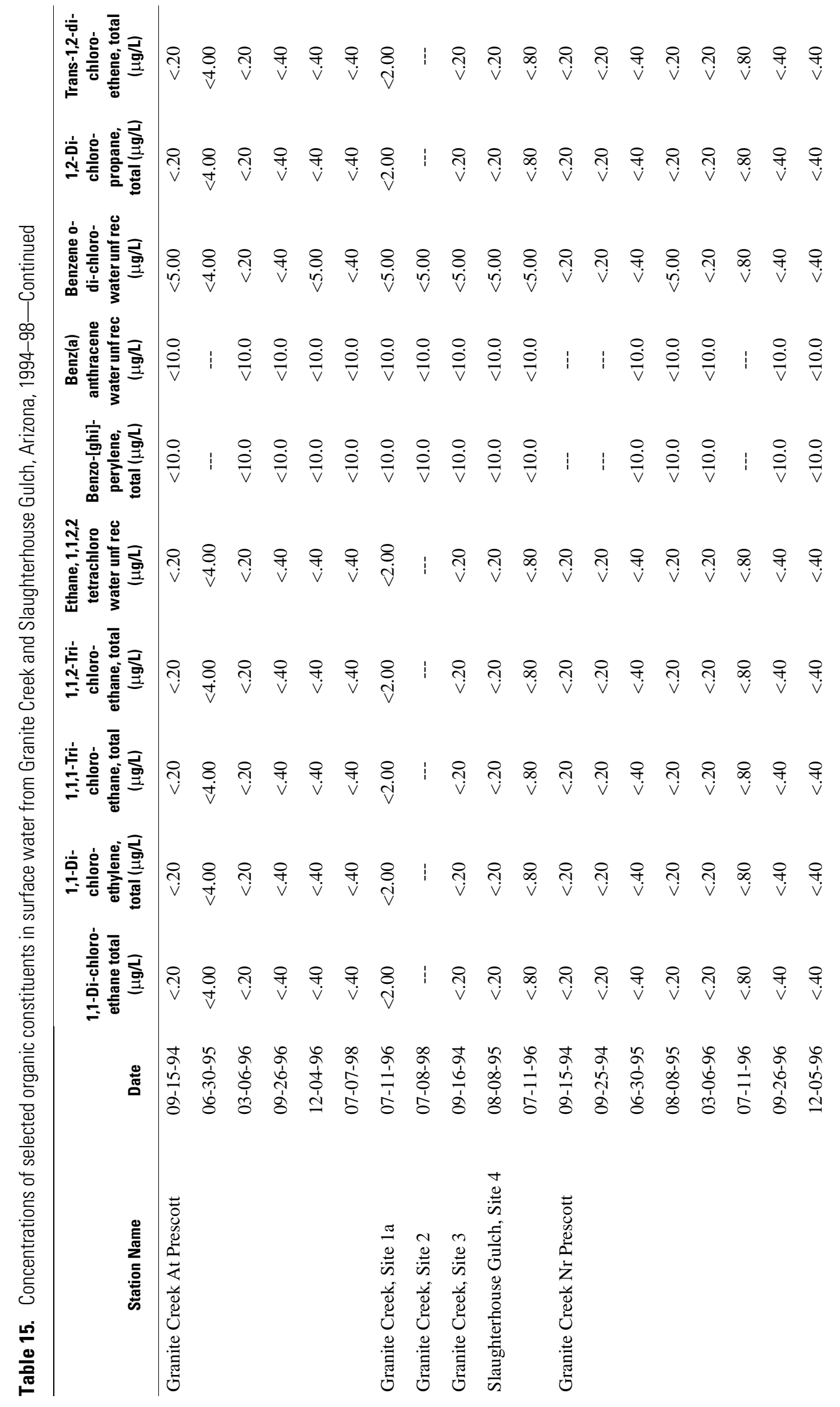

56 Occurrence and Quality of Surface Water and Ground Water within the Yapavai-Prescott Indian Reservation 


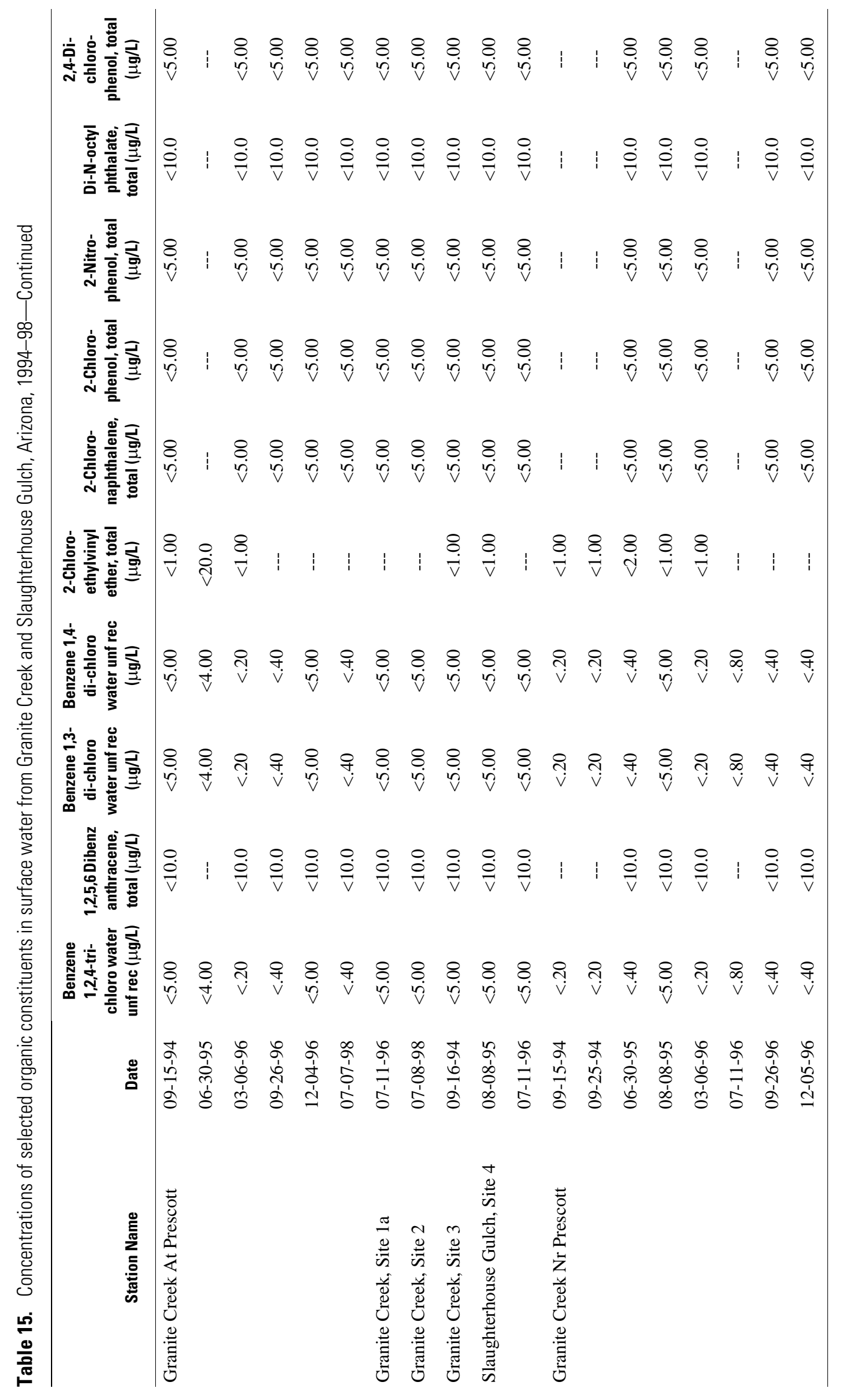




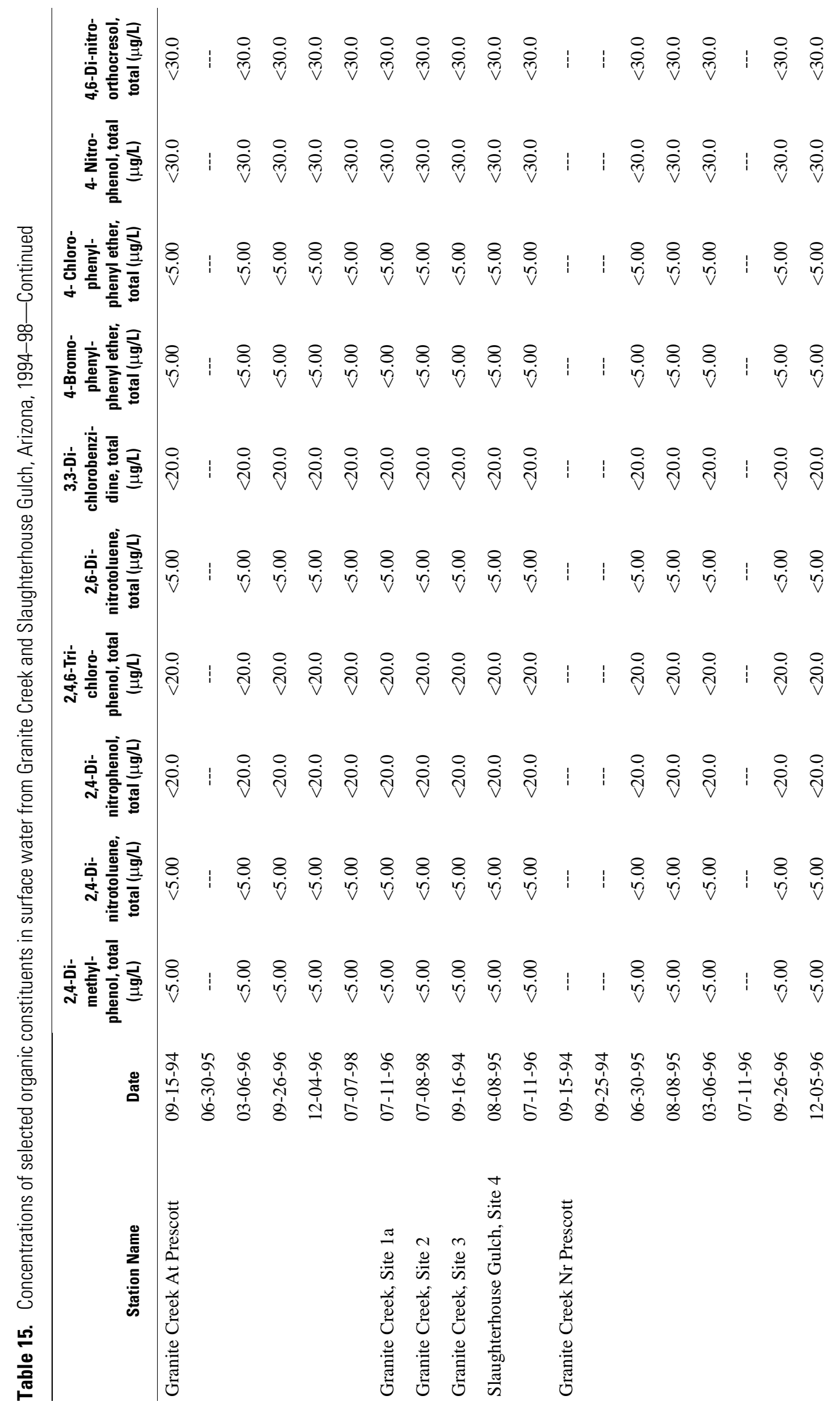

58 Occurrence and Quality of Surface Water and Ground Water within the Yapavai-Prescott Indian Reservation 


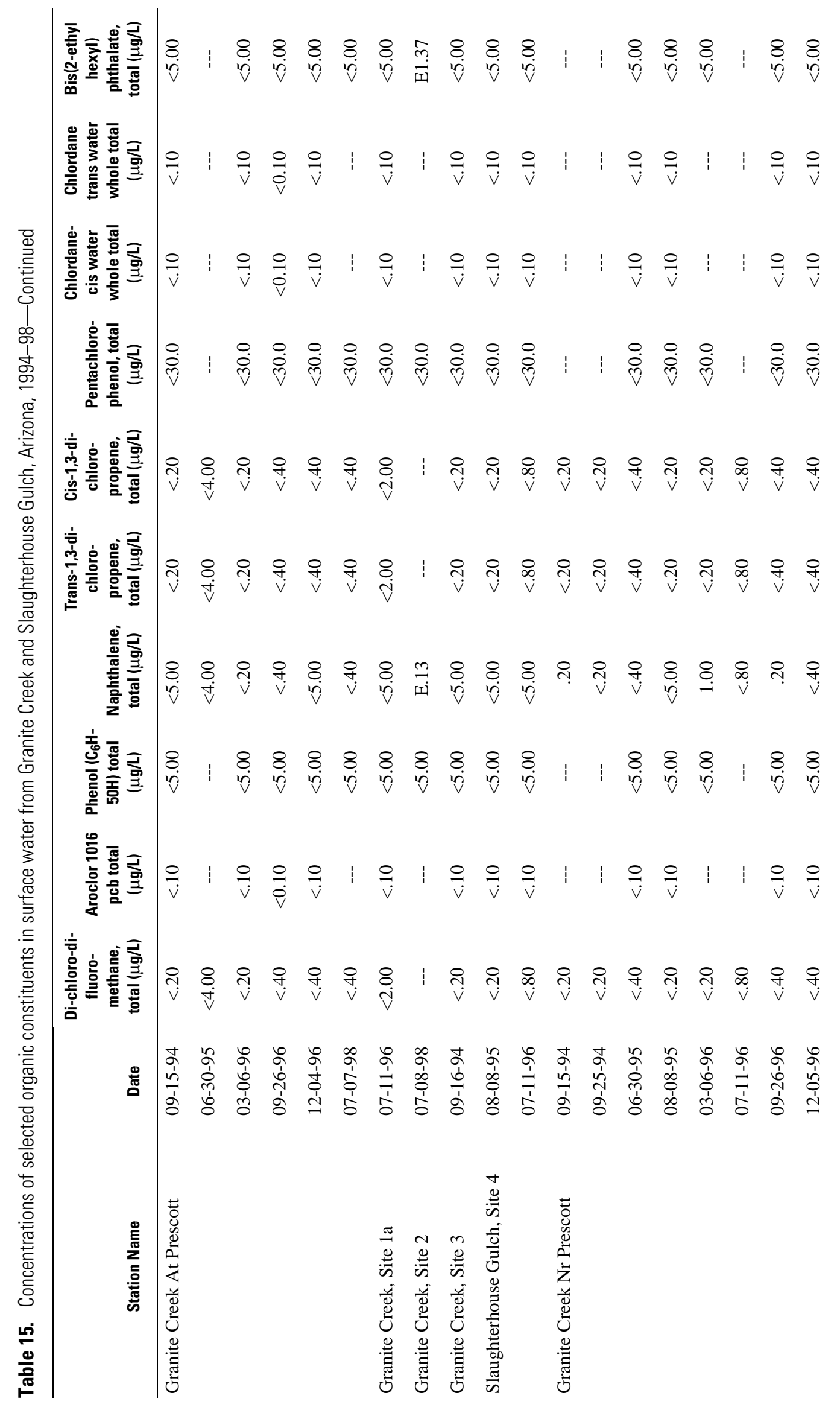




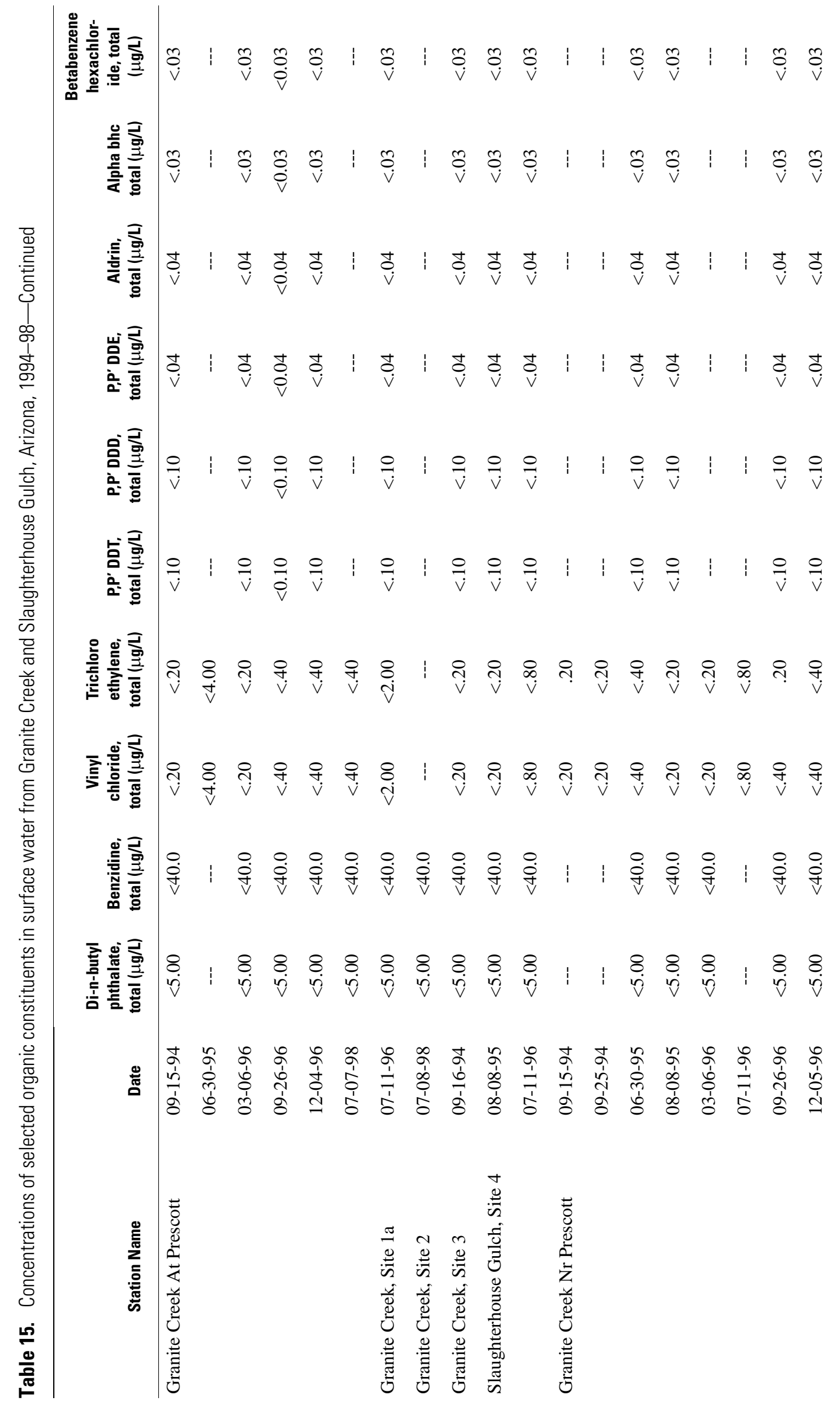

60 Occurrence and Quality of Surface Water and Ground Water within the Yapavai-Prescott Indian Reservation 


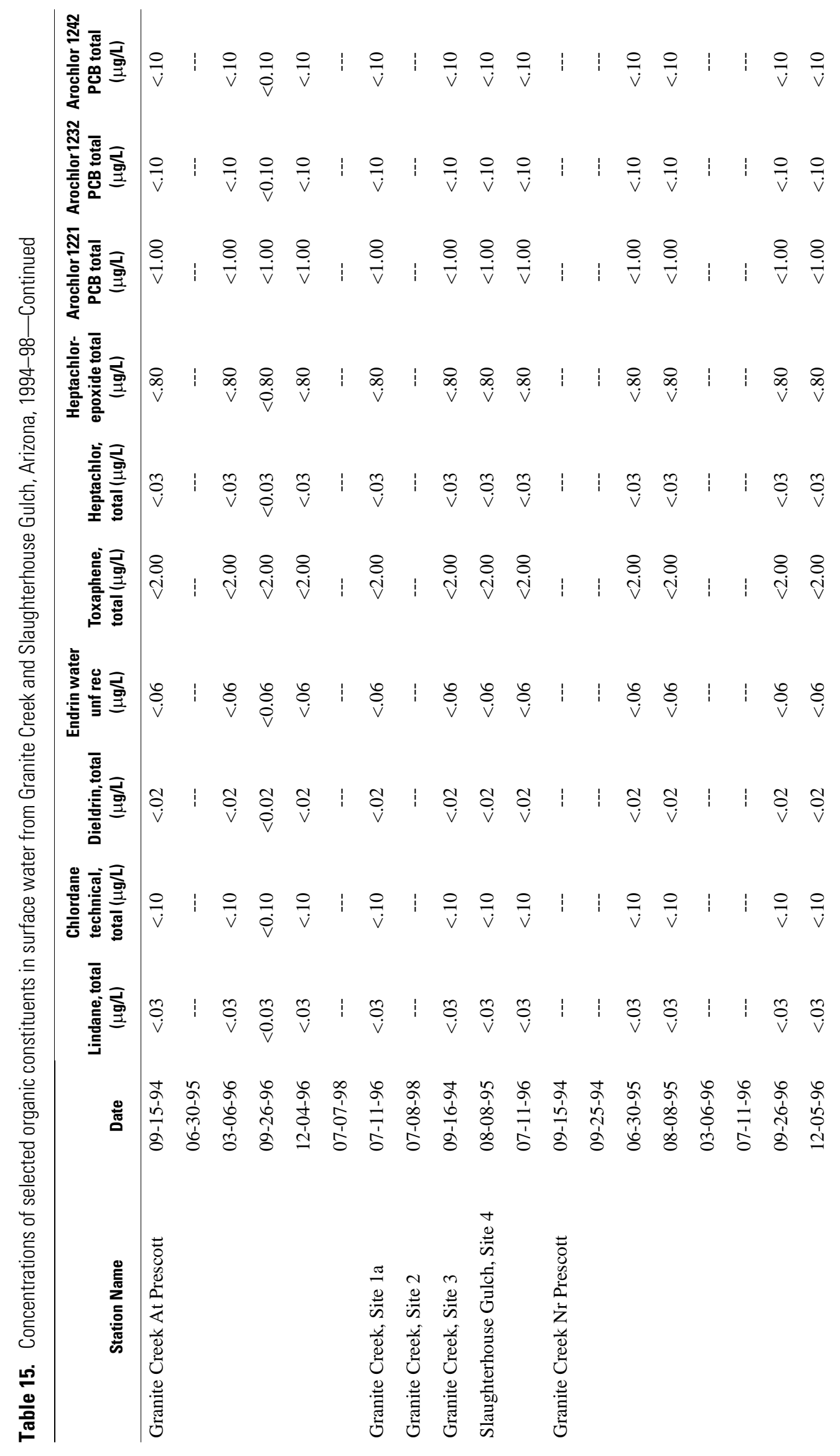




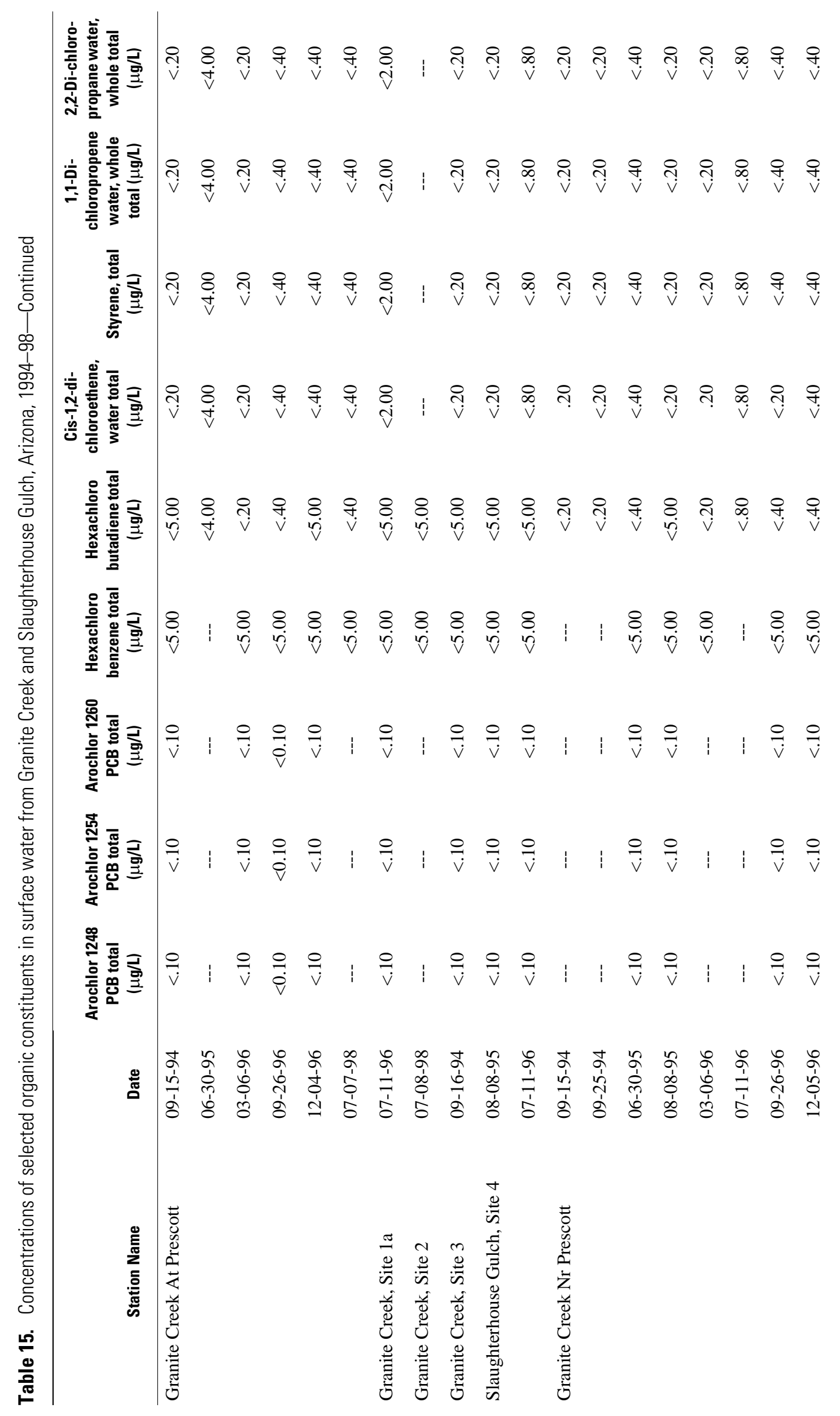




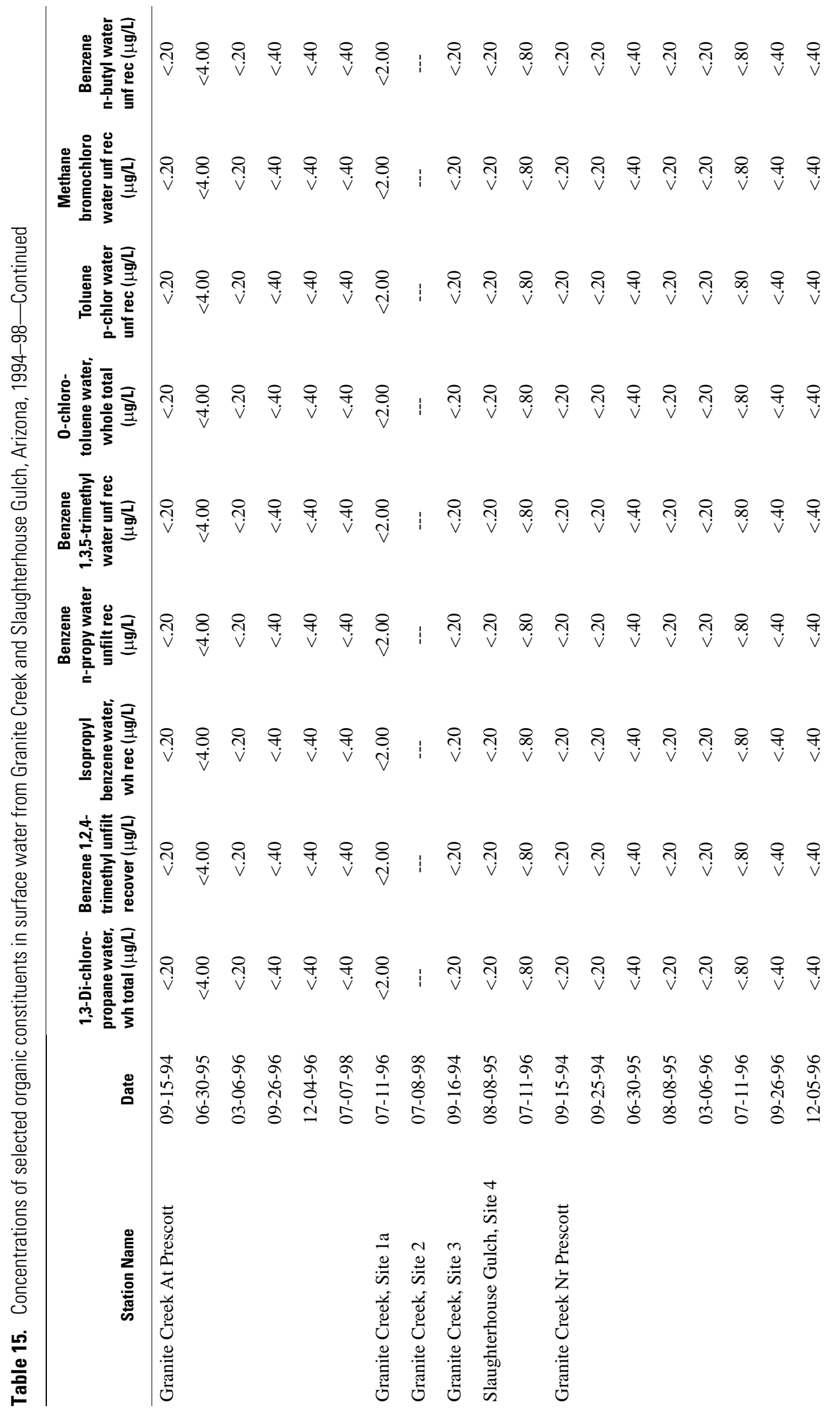




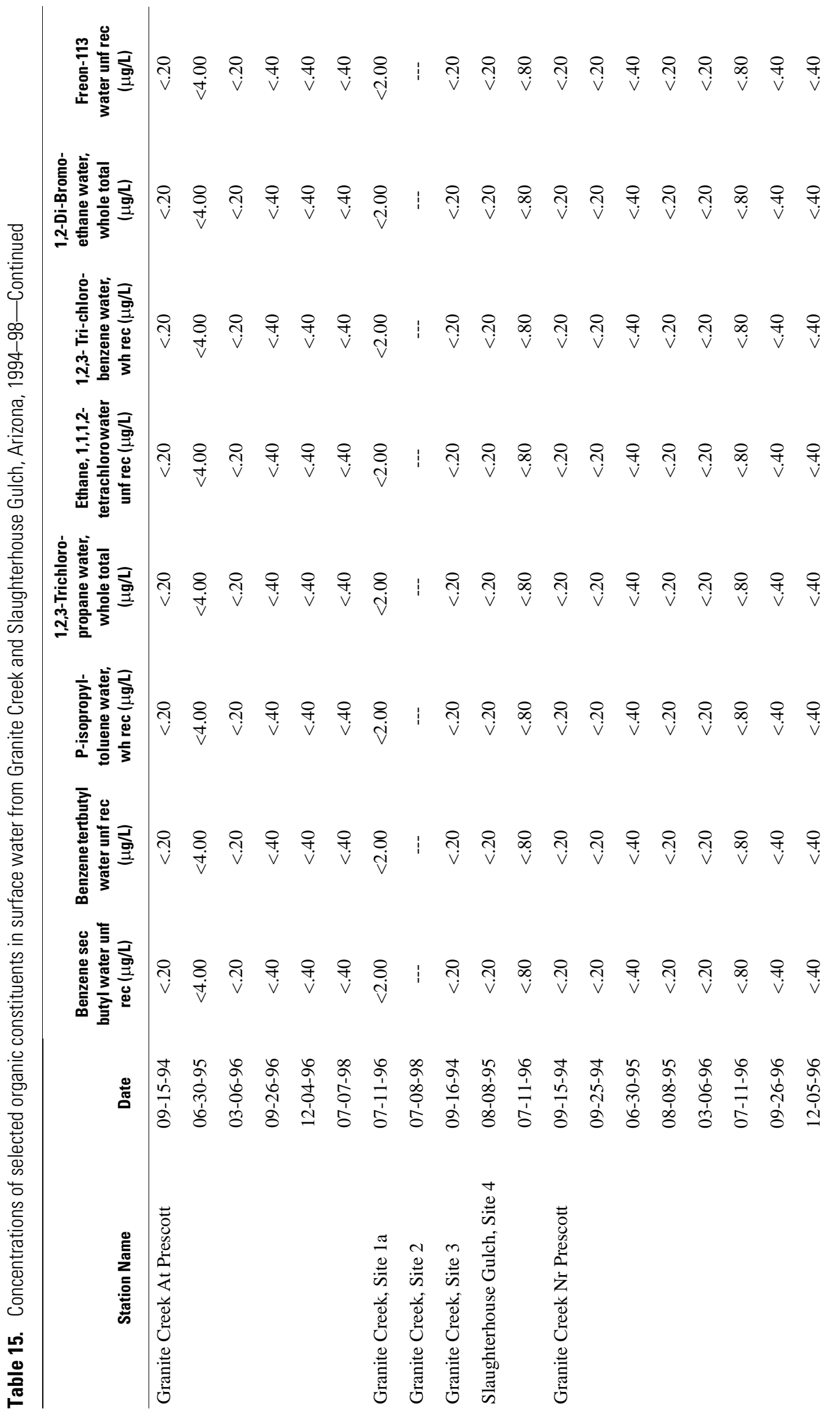

64 Occurrence and Quality of Surface Water and Ground Water within the Yapavai-Prescott Indian Reservation 


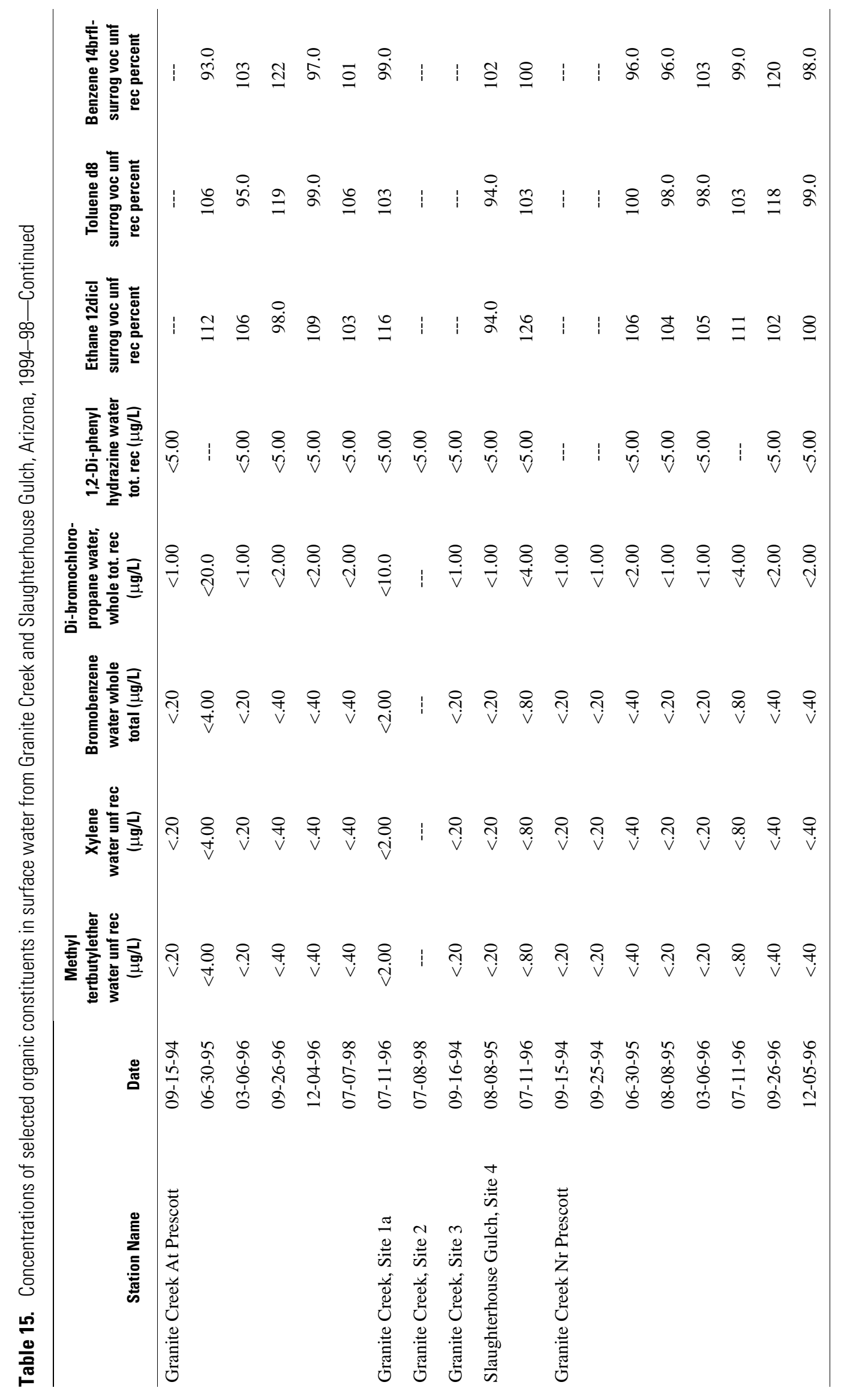




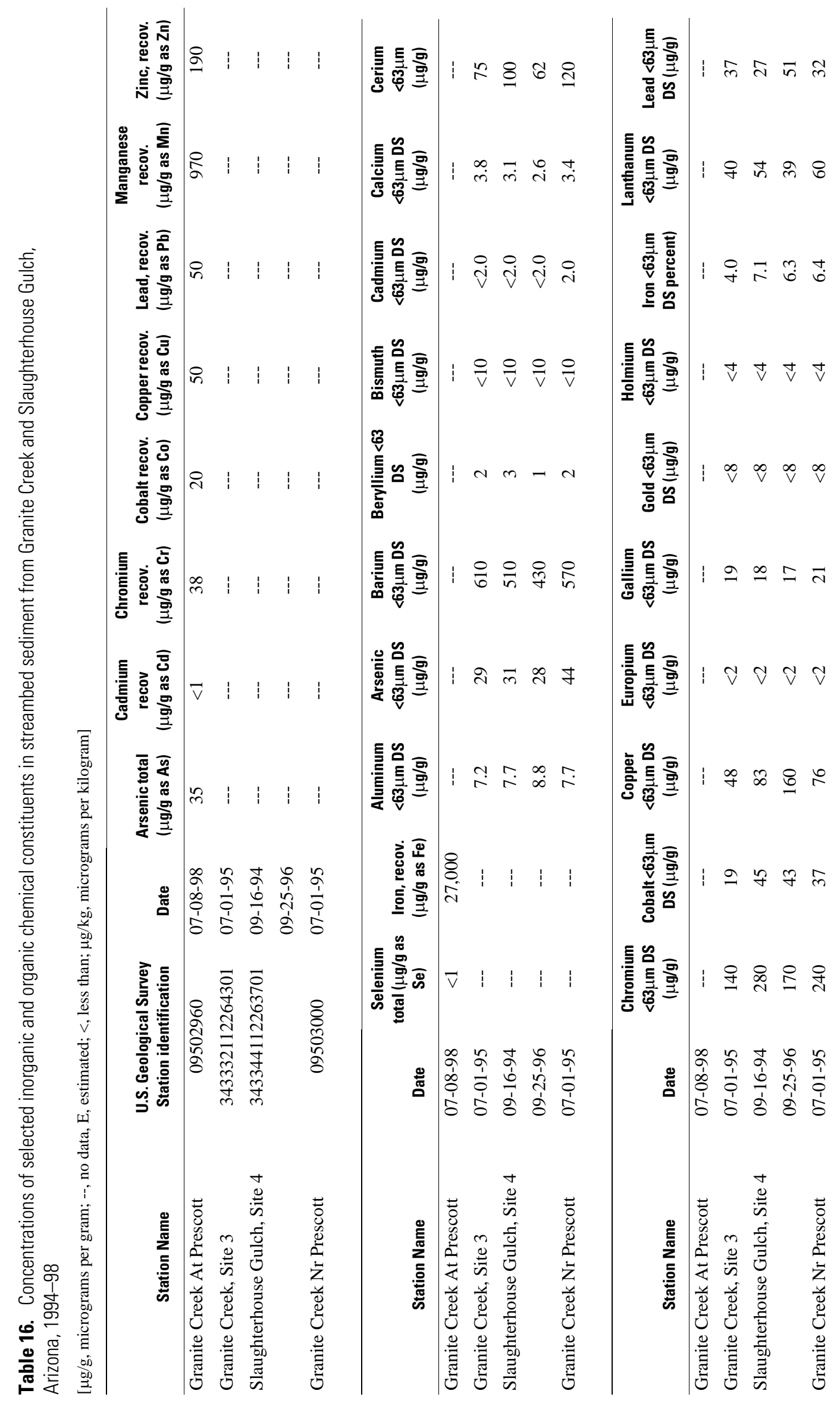

66 Occurrence and Quality of Surface Water and Ground Water within the Yapavai-Prescott Indian Reservation 


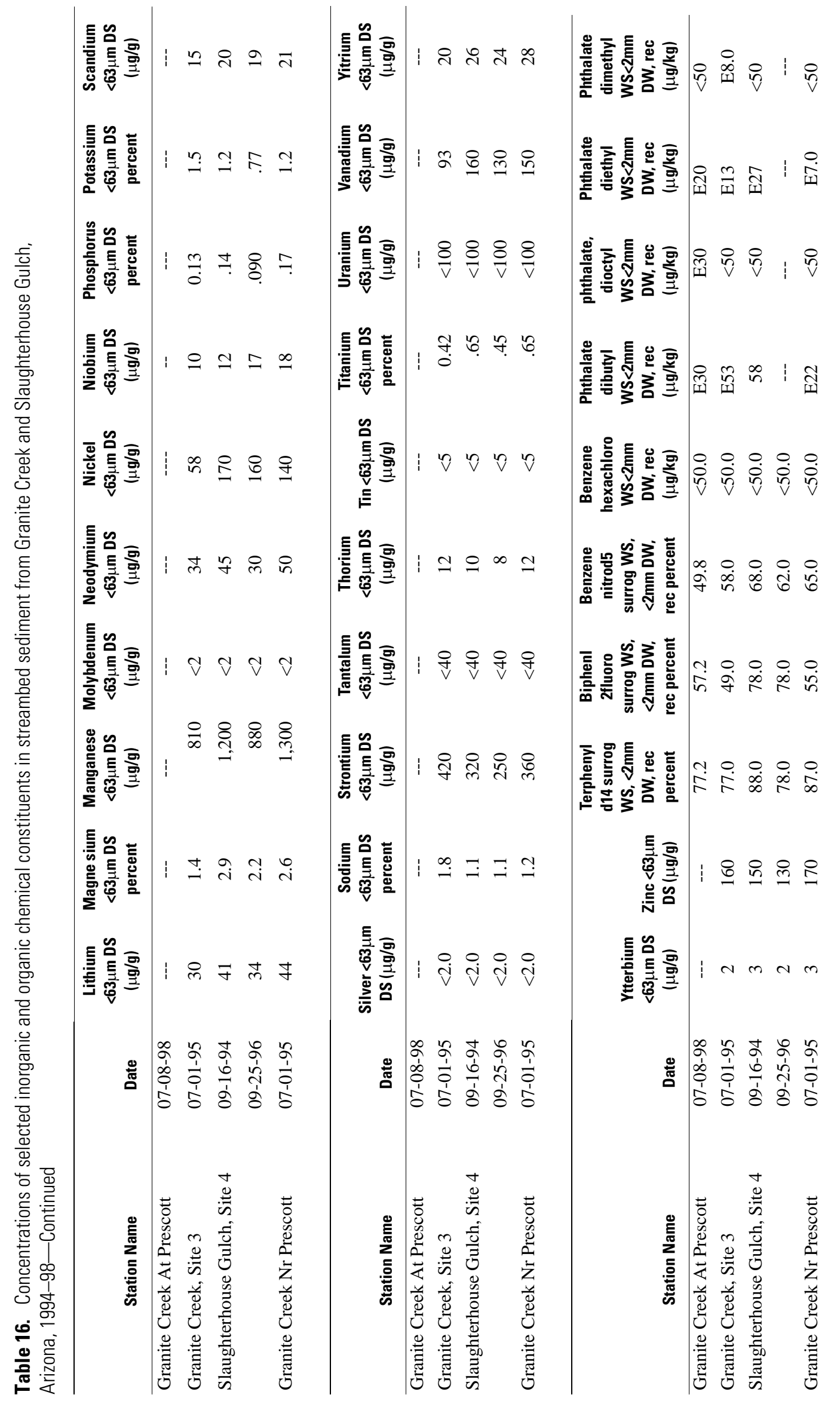




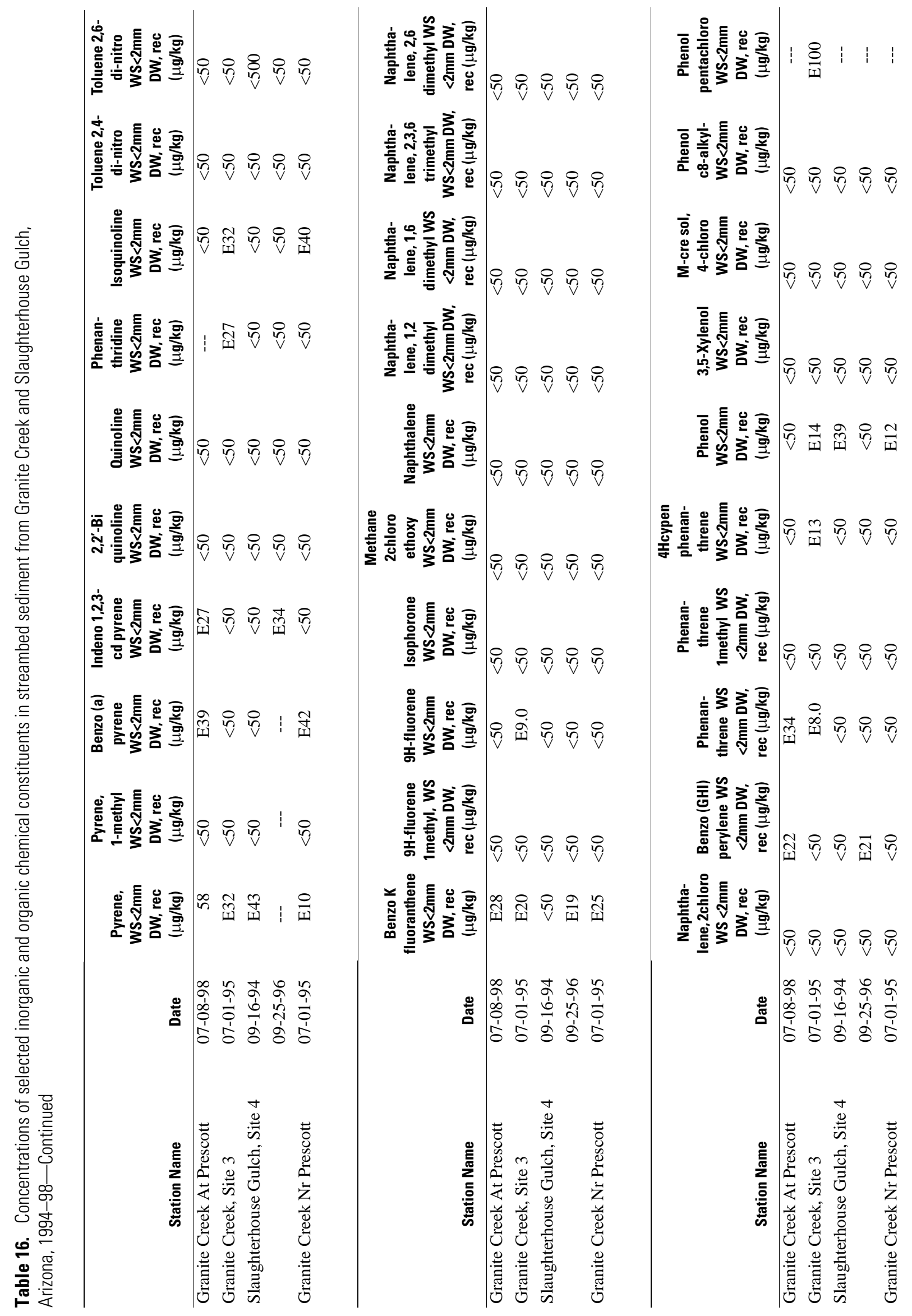




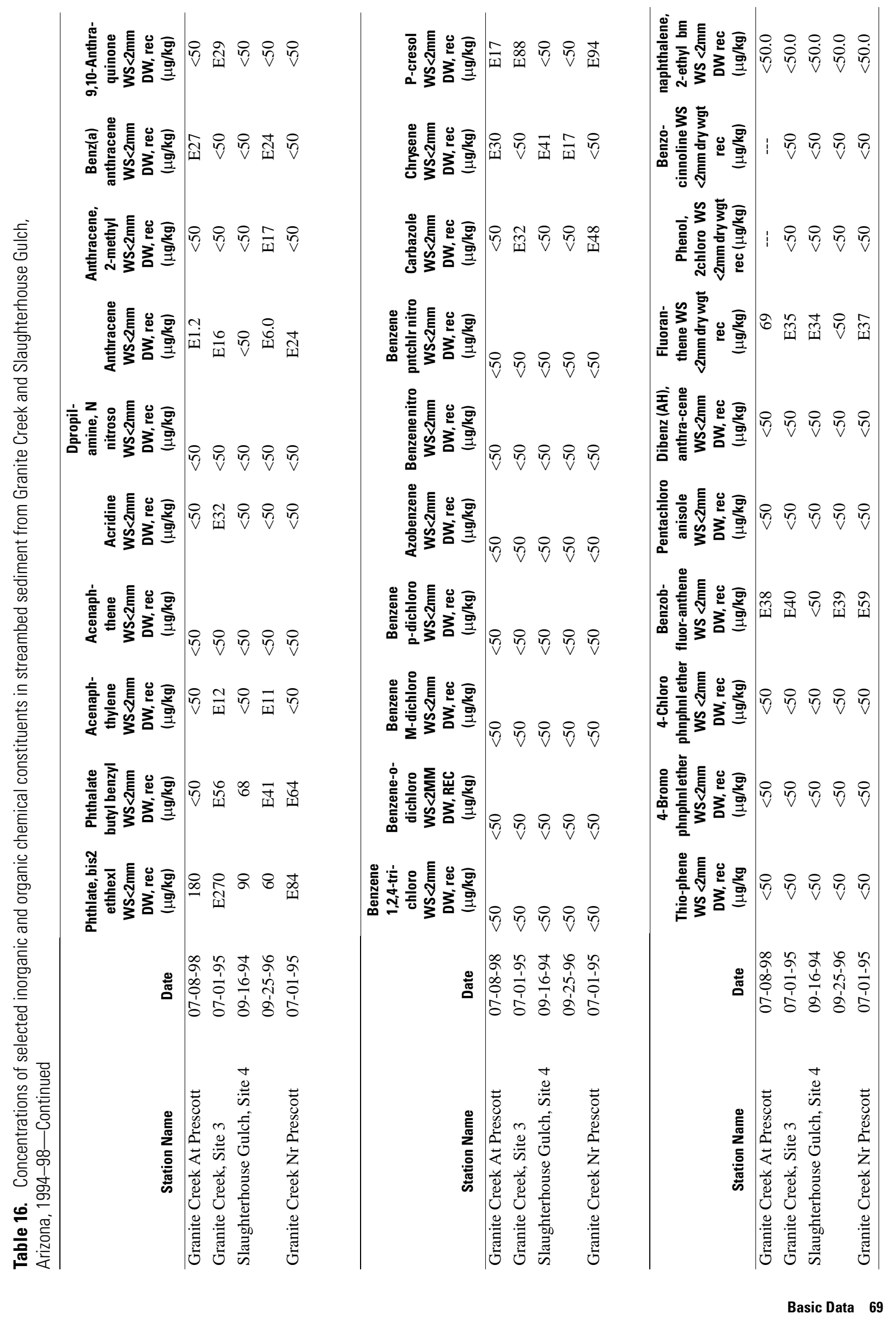




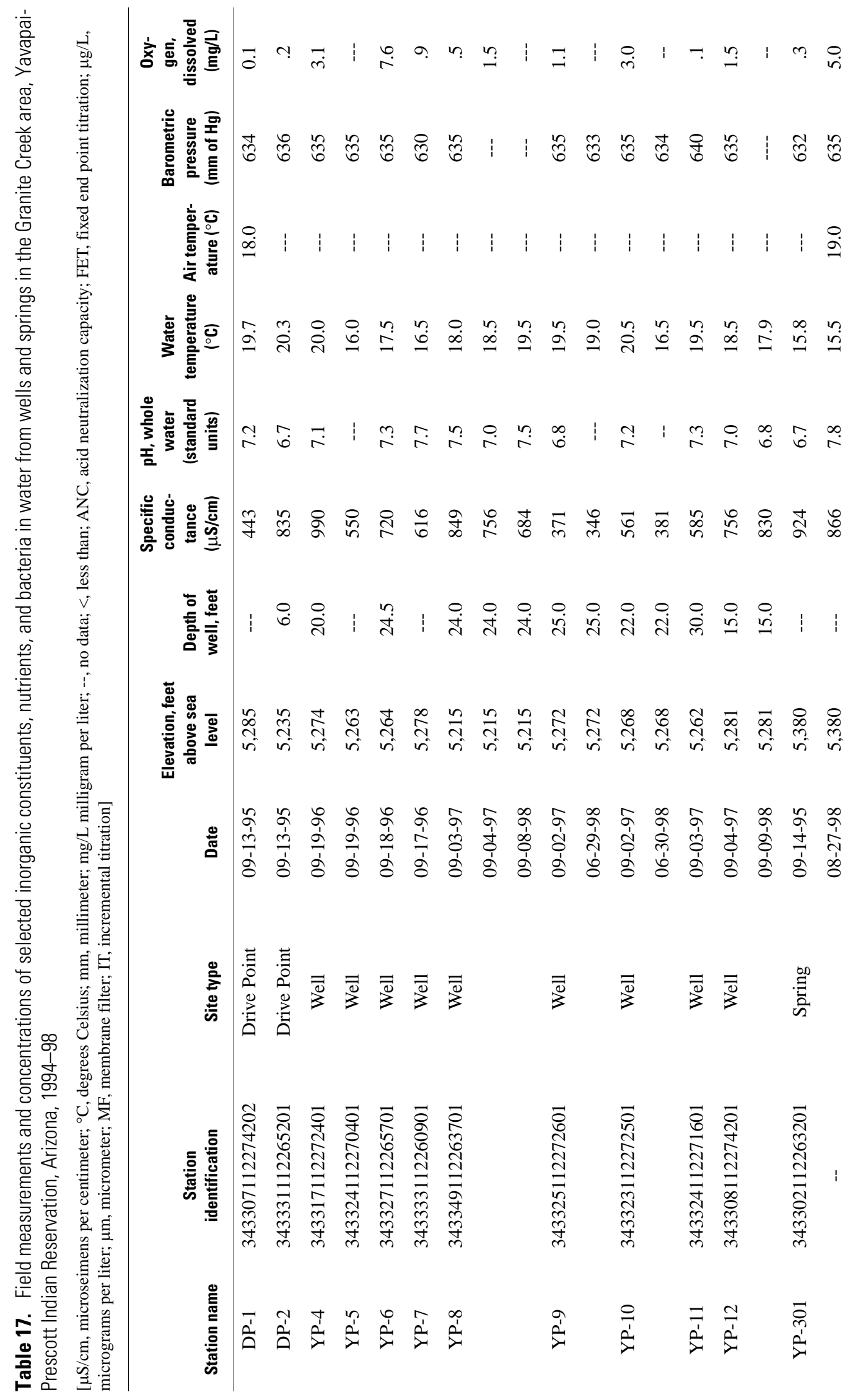




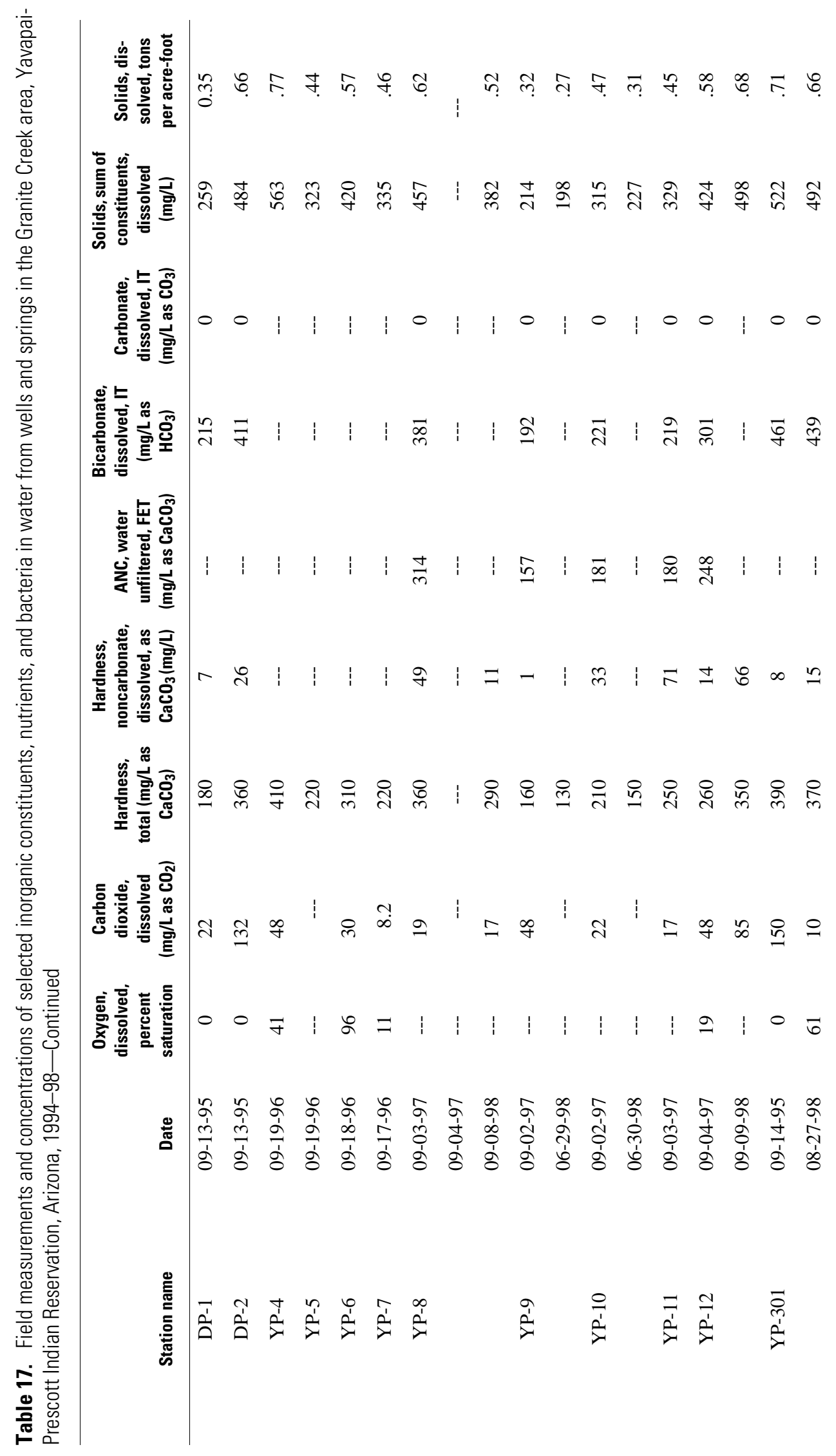




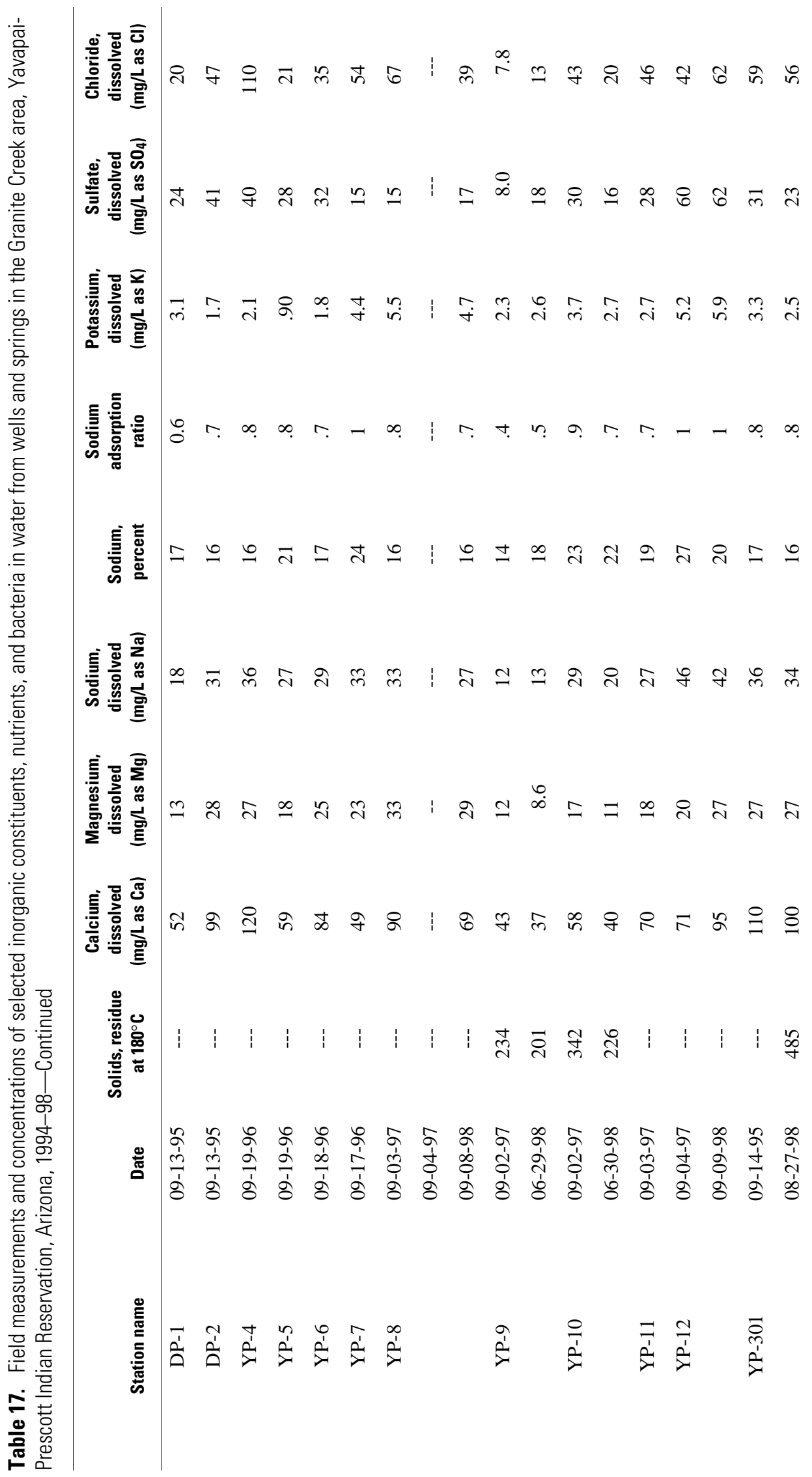




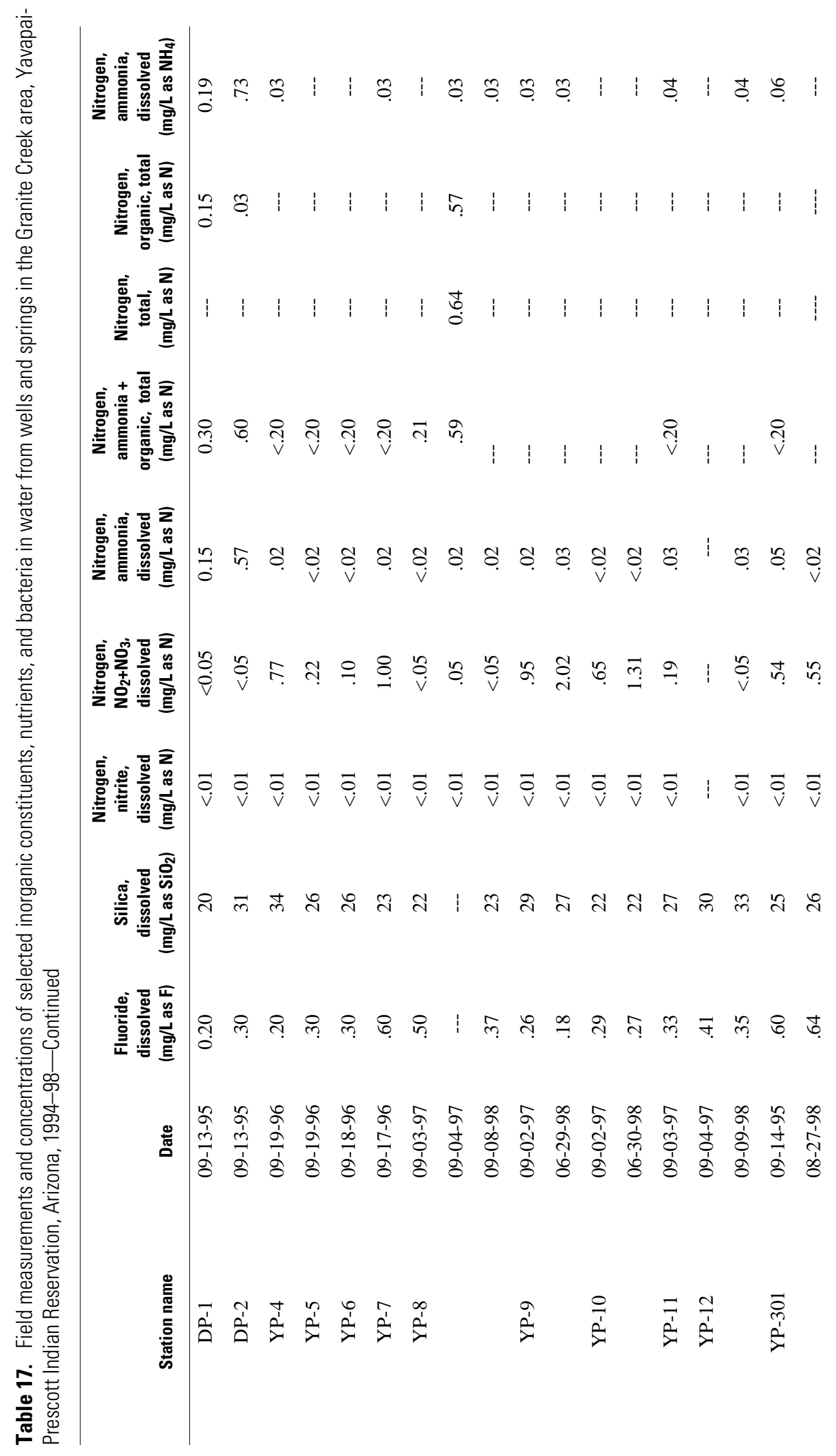




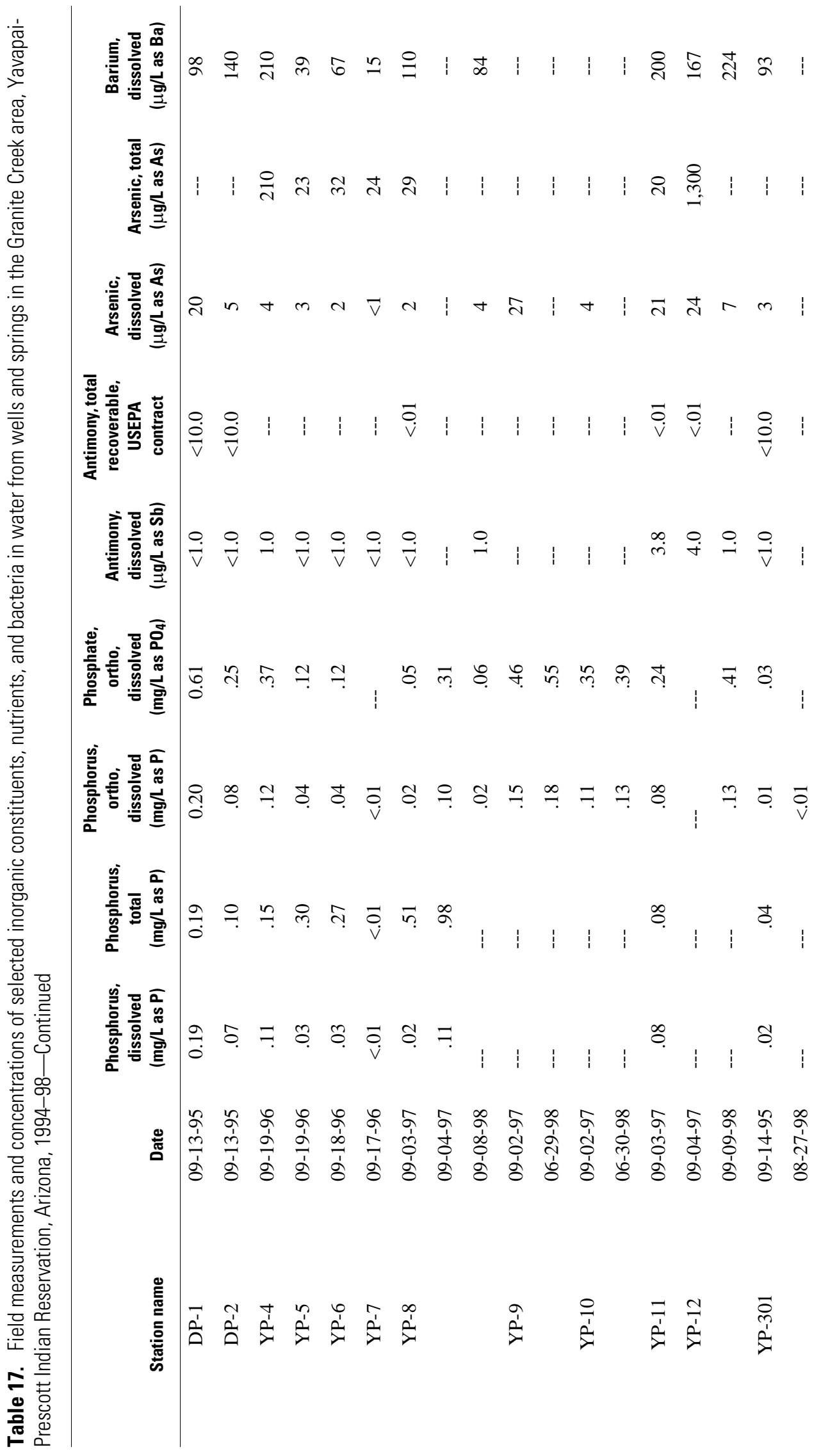




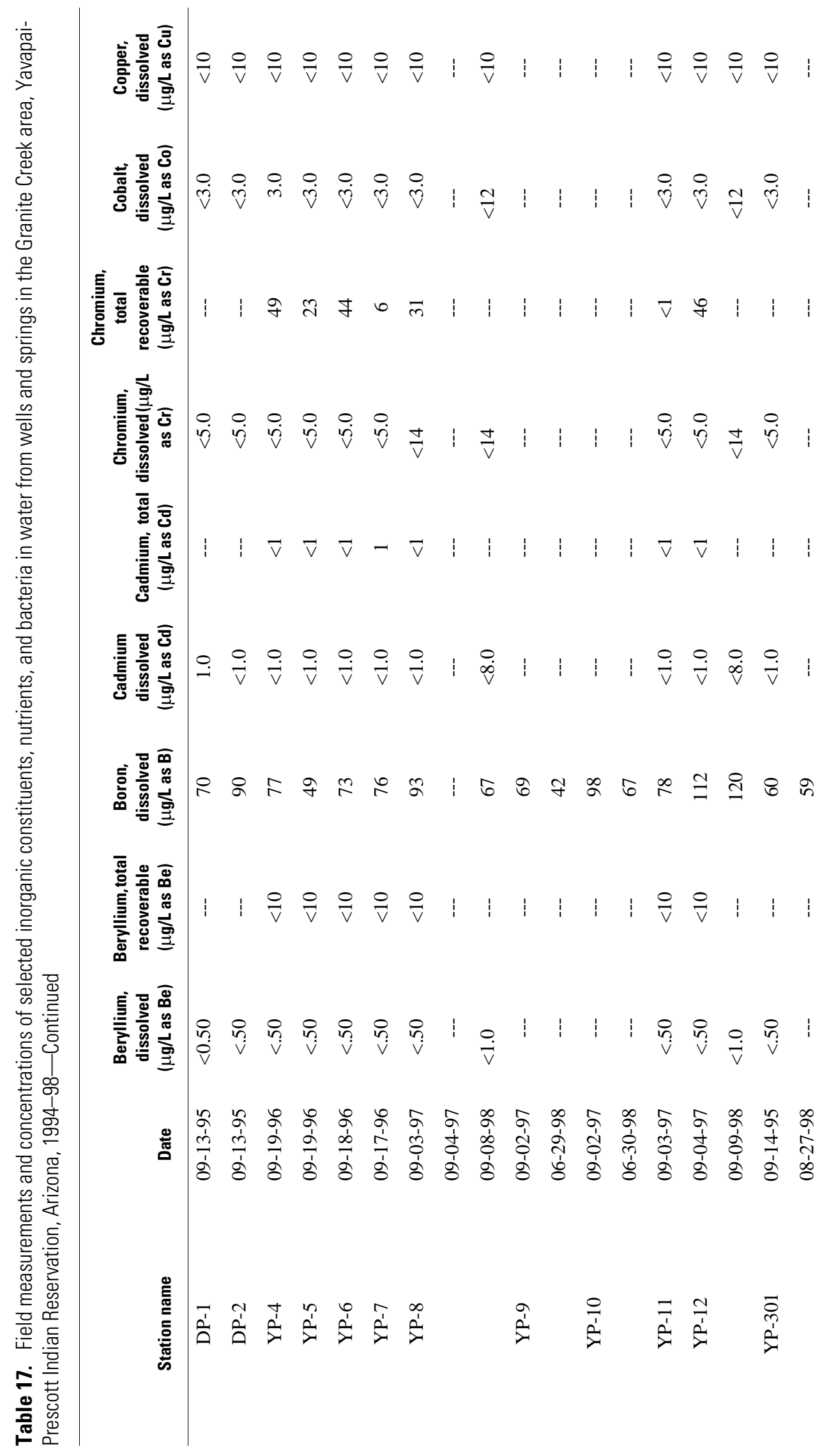




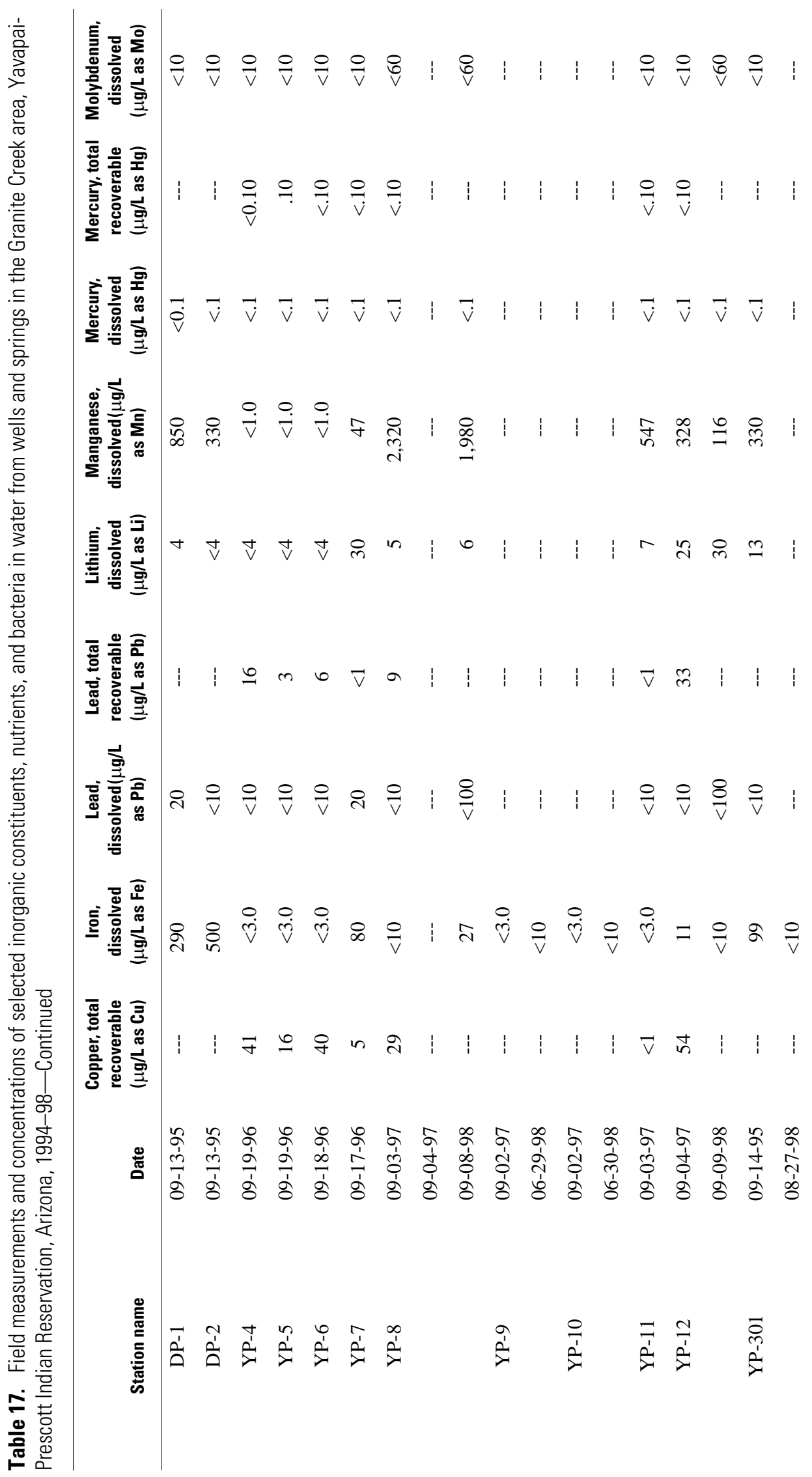




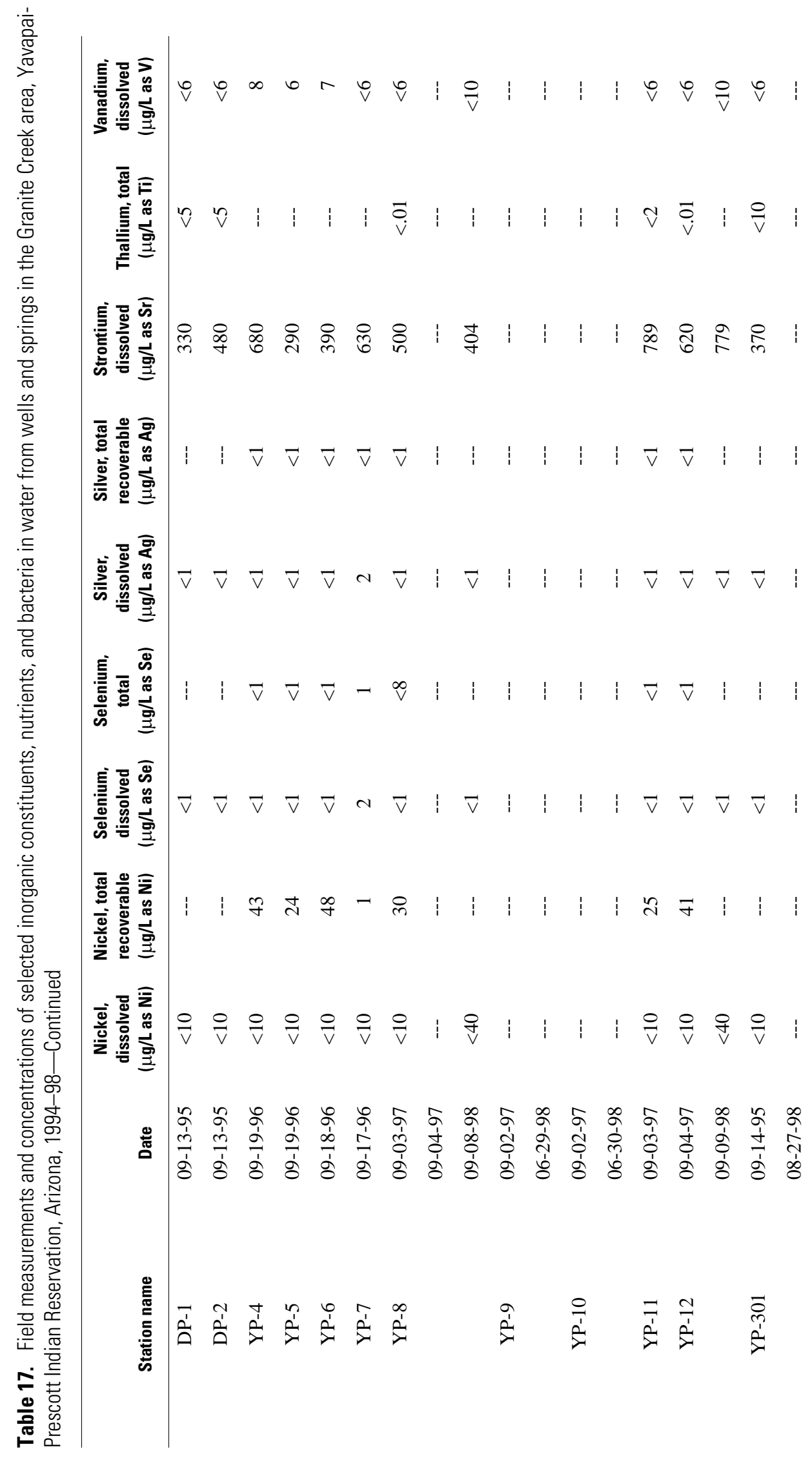




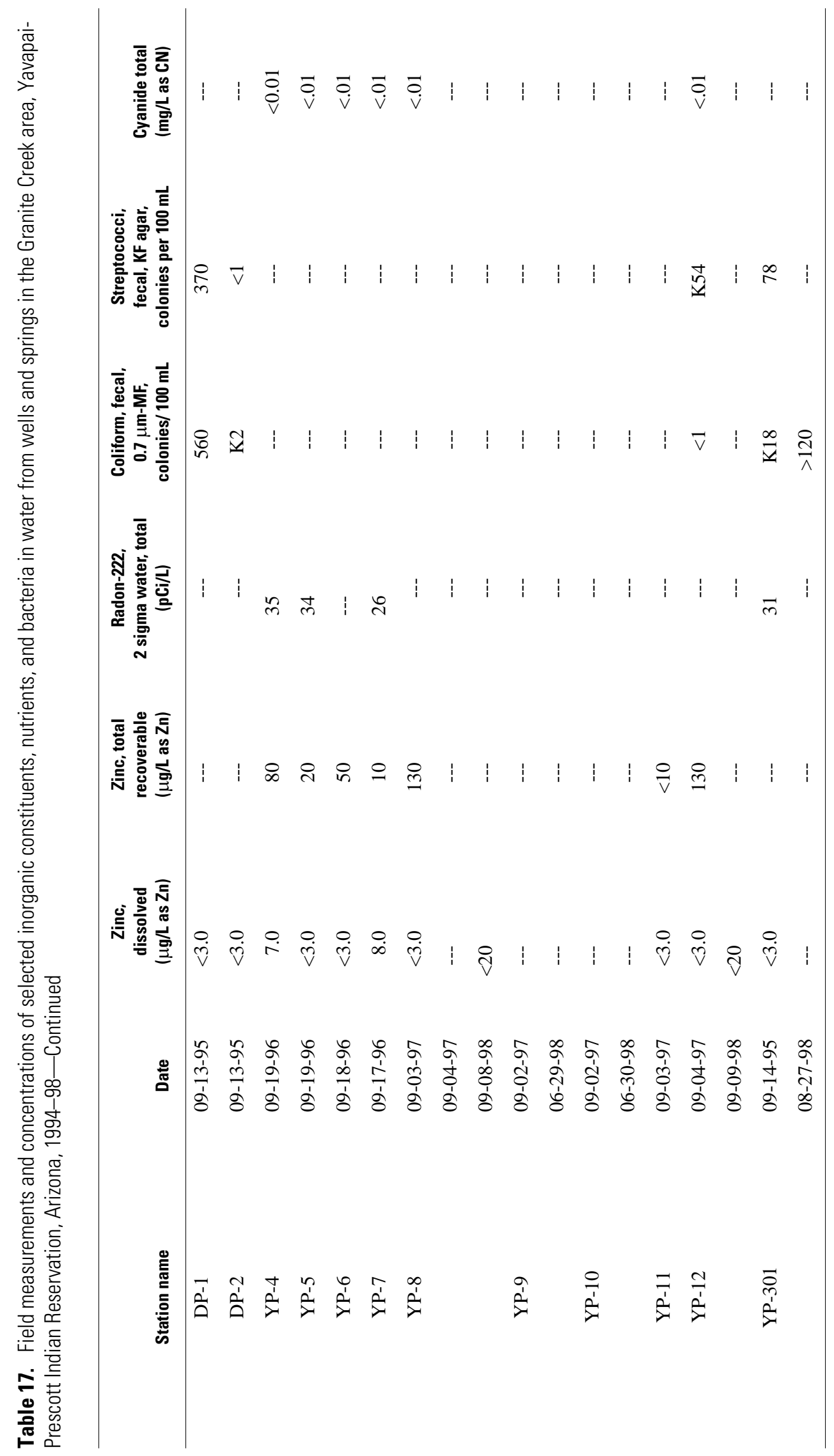




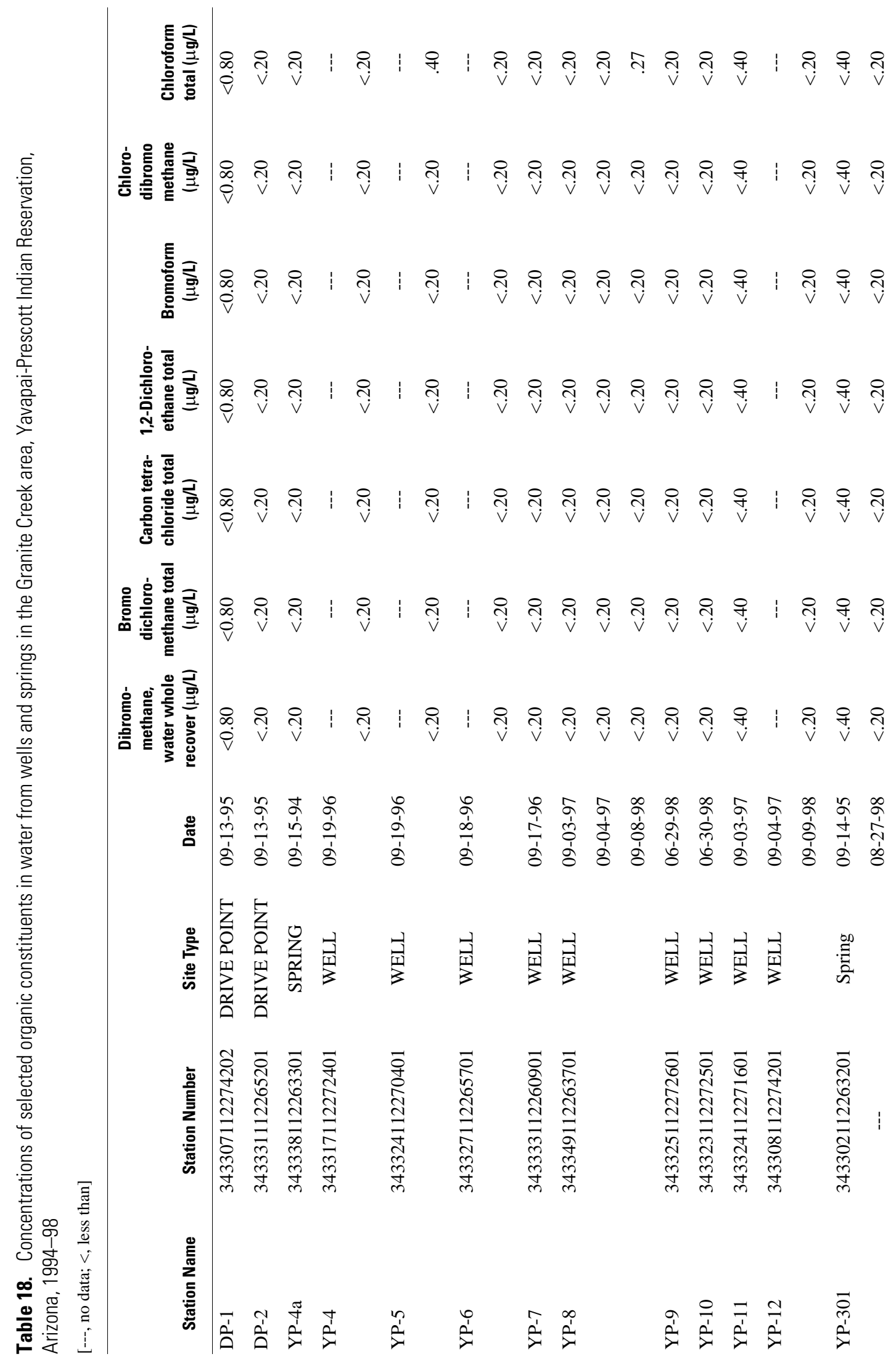




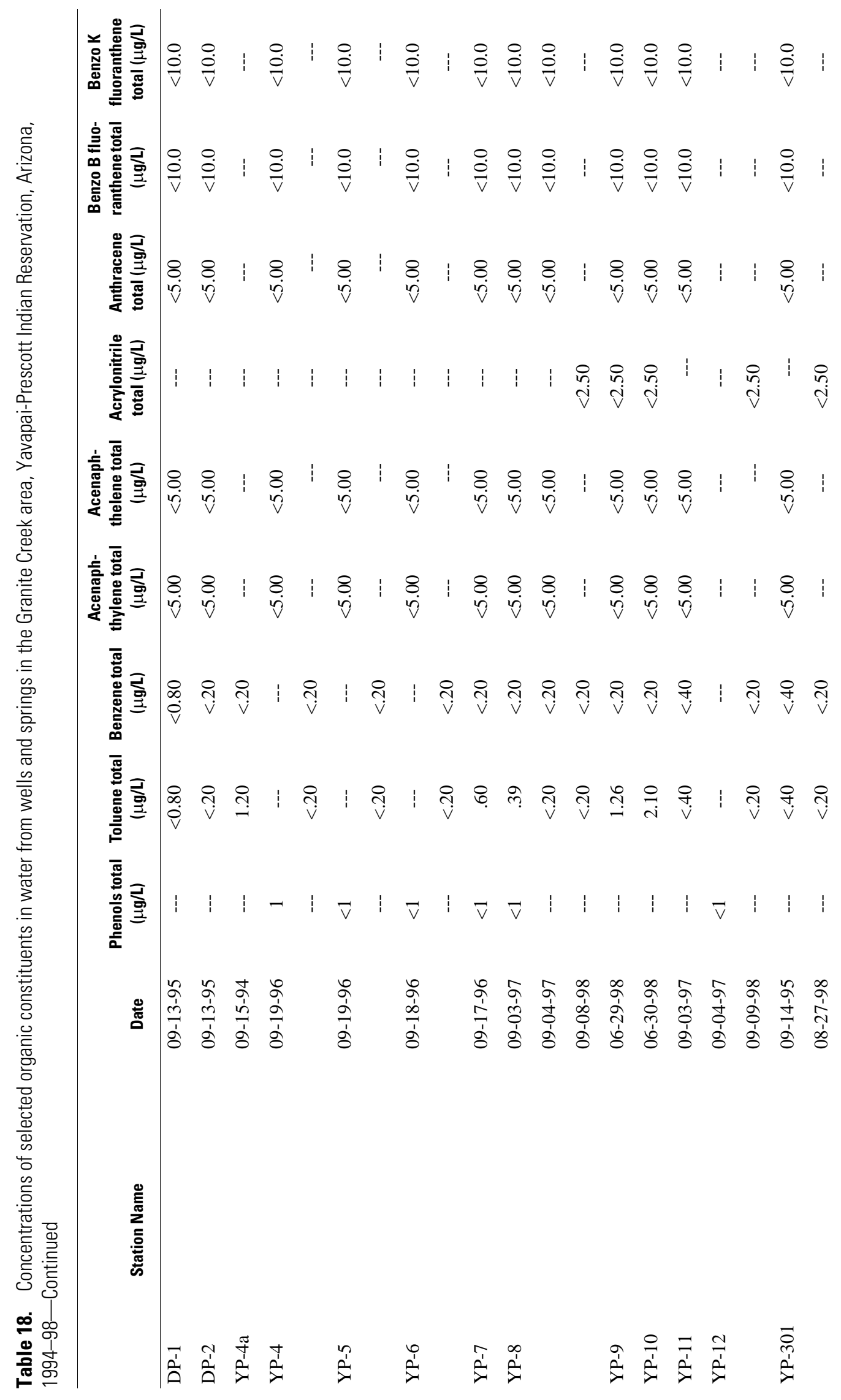

80 Occurrence and Quality of Surface Water and Ground Water within the Yapavai-Prescott Indian Reservation 


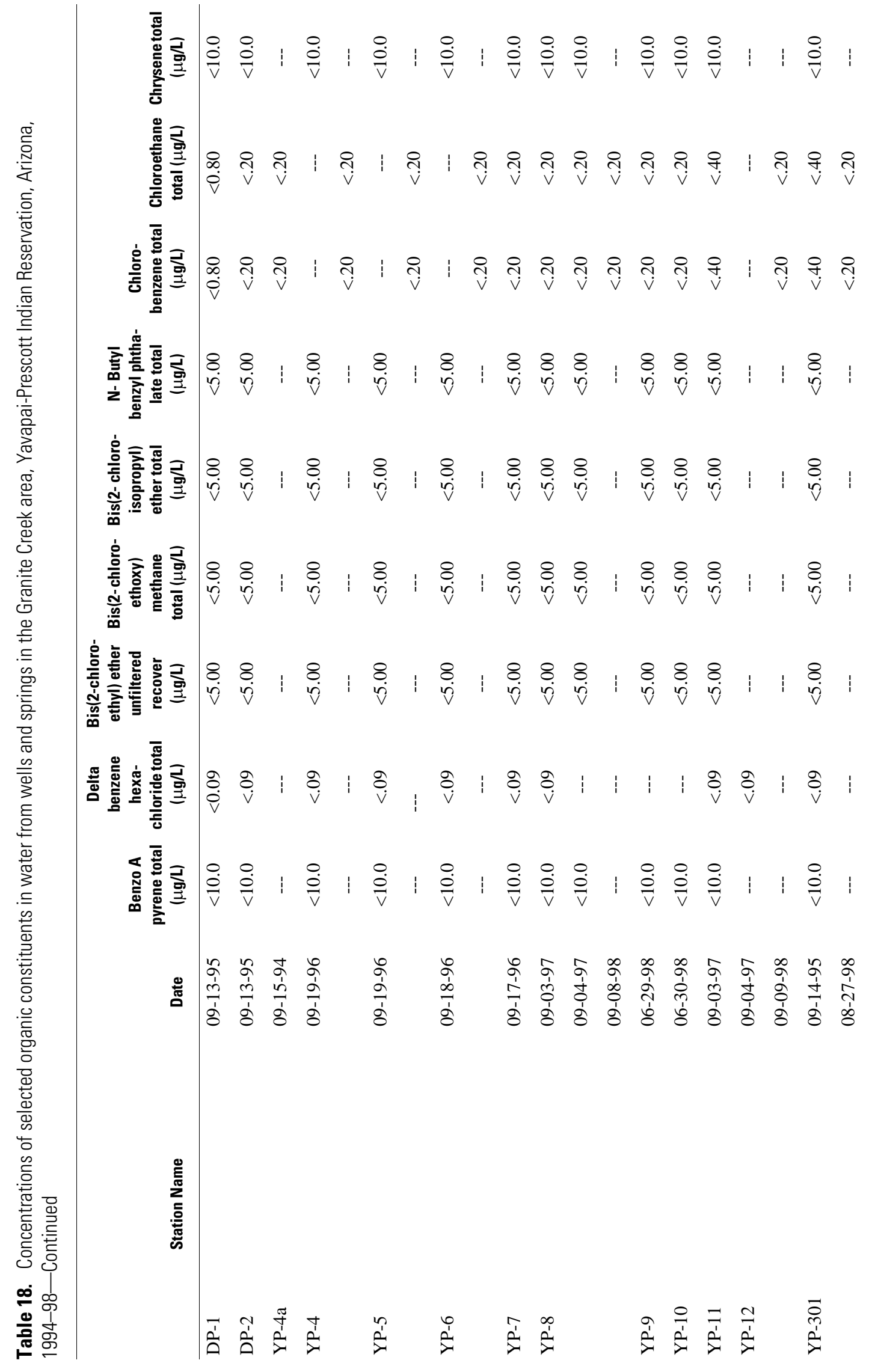




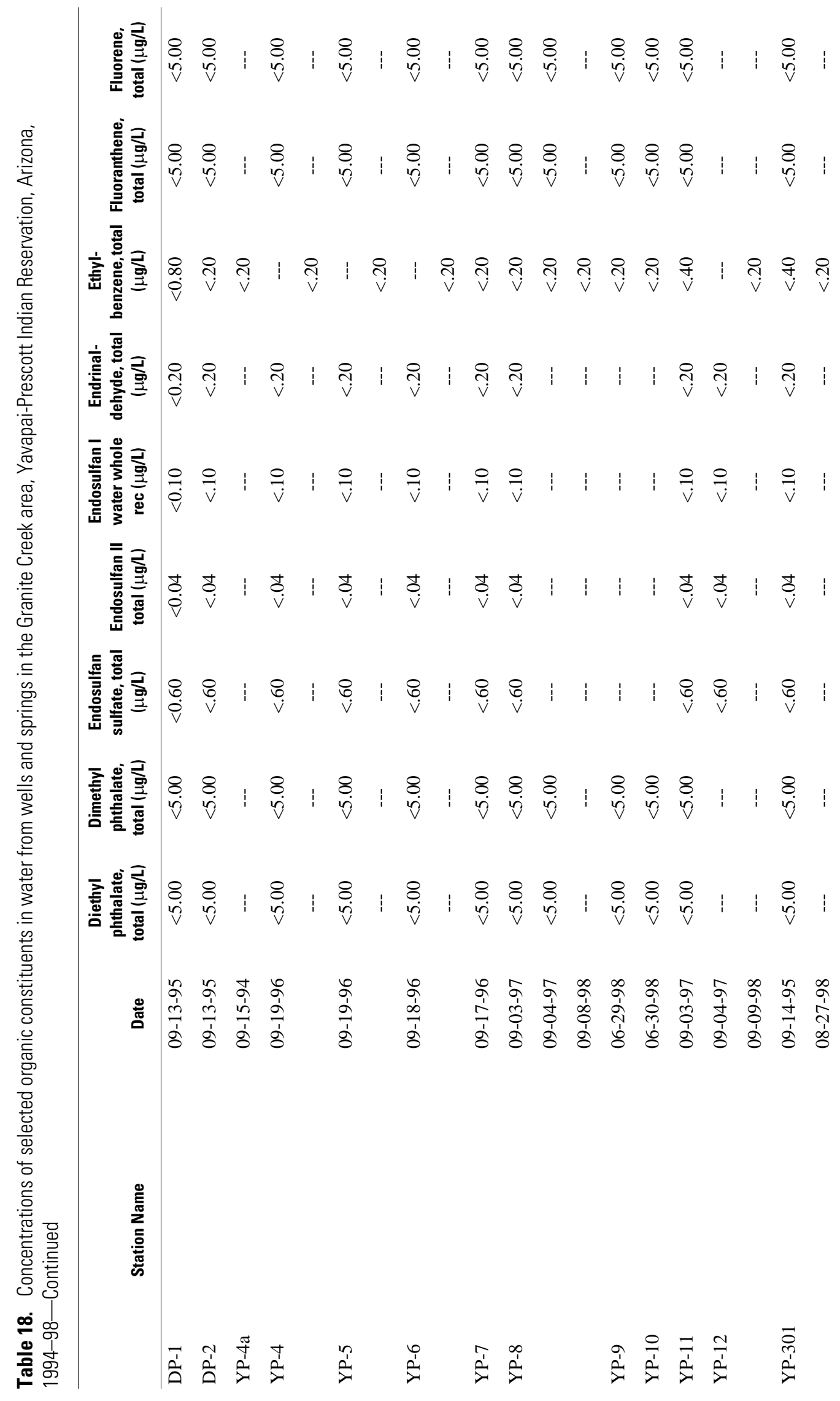




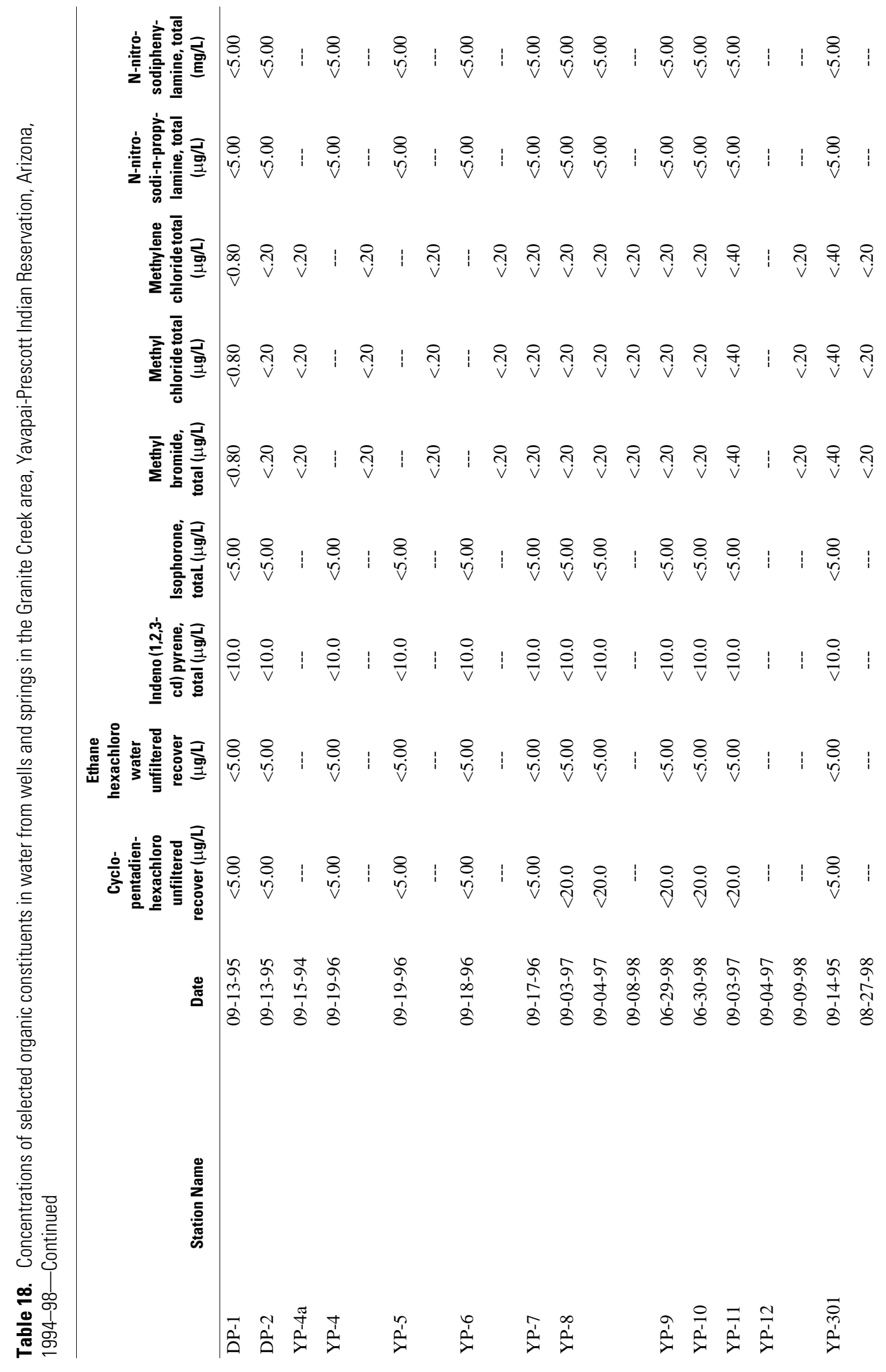




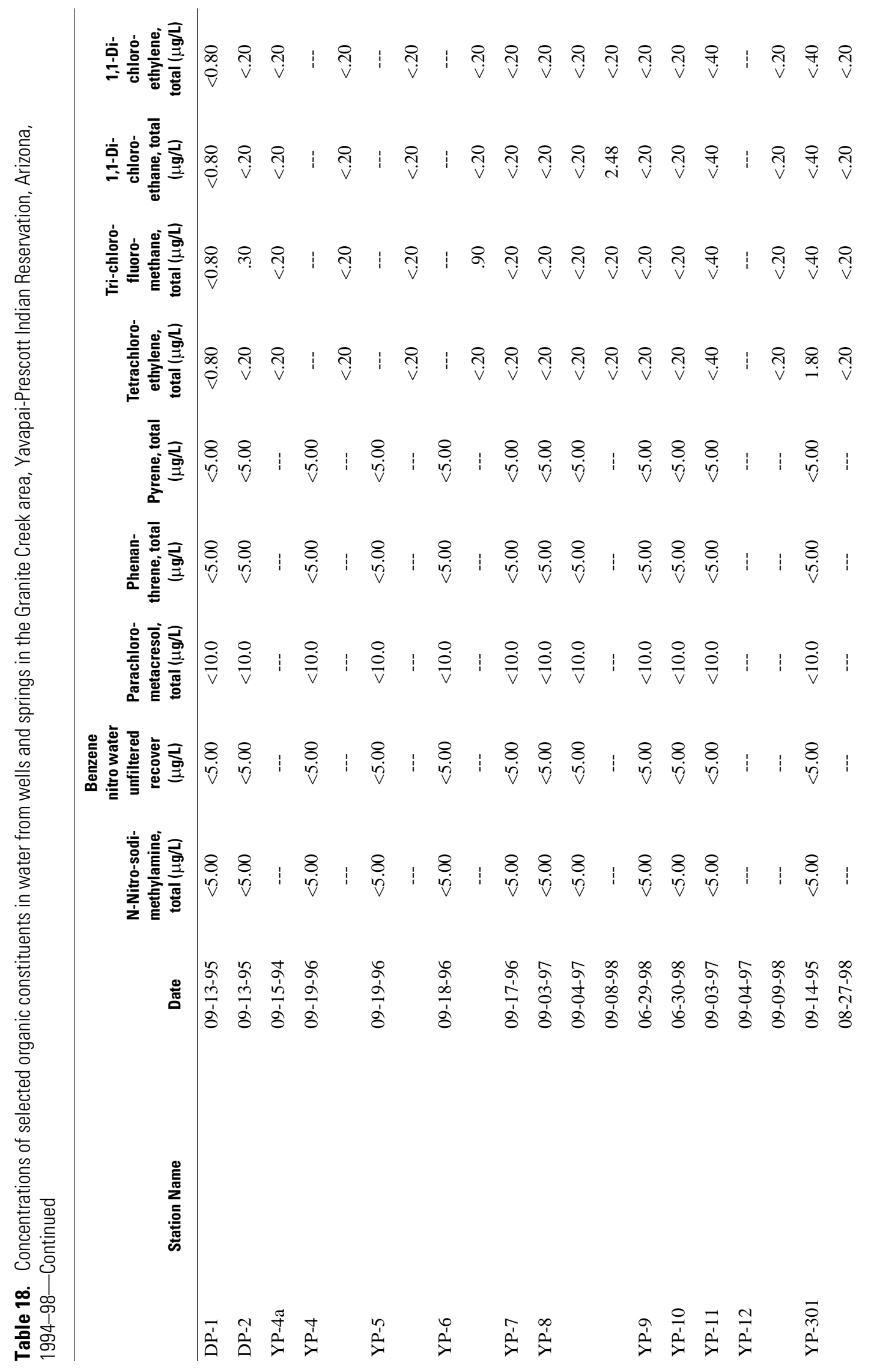




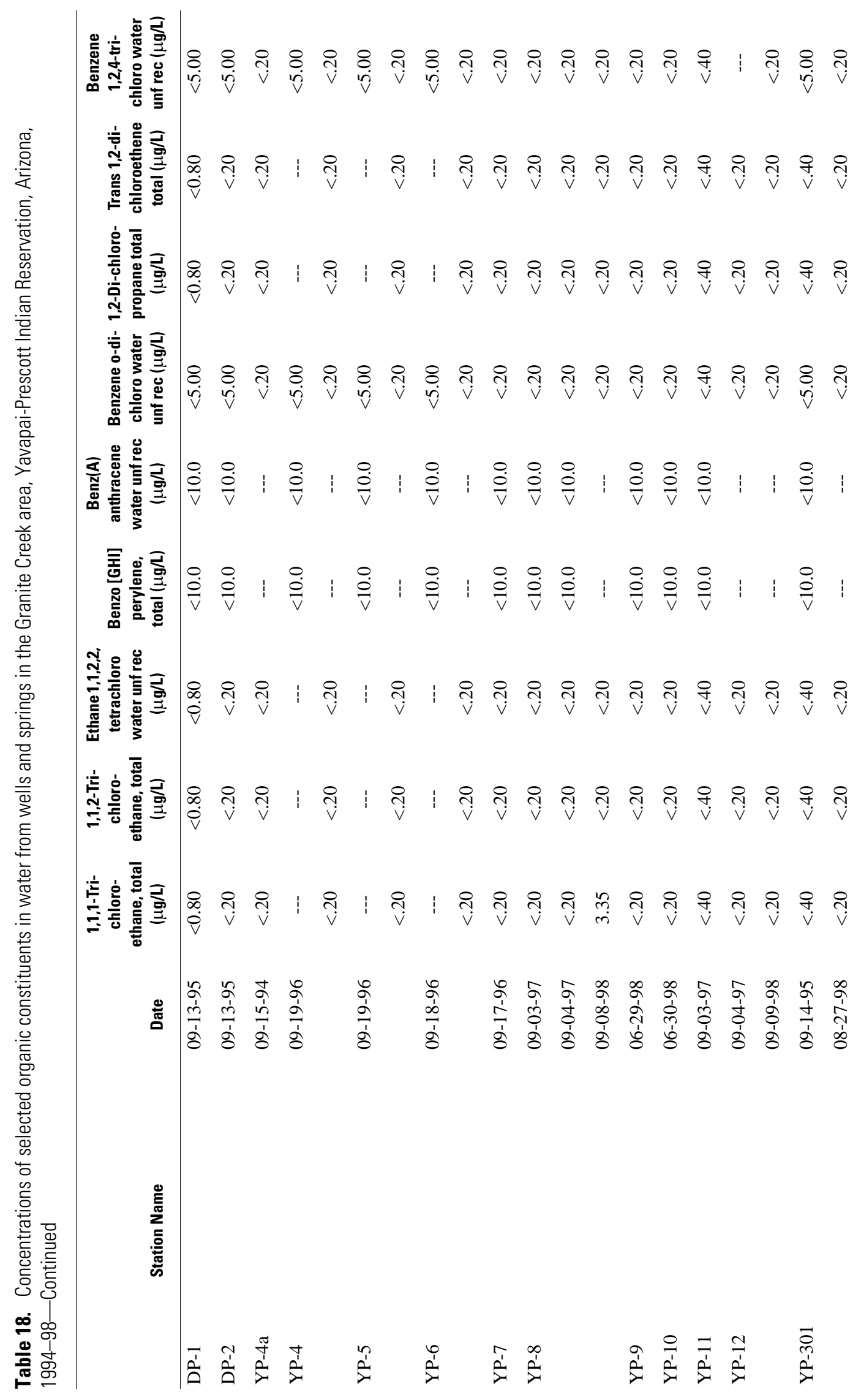




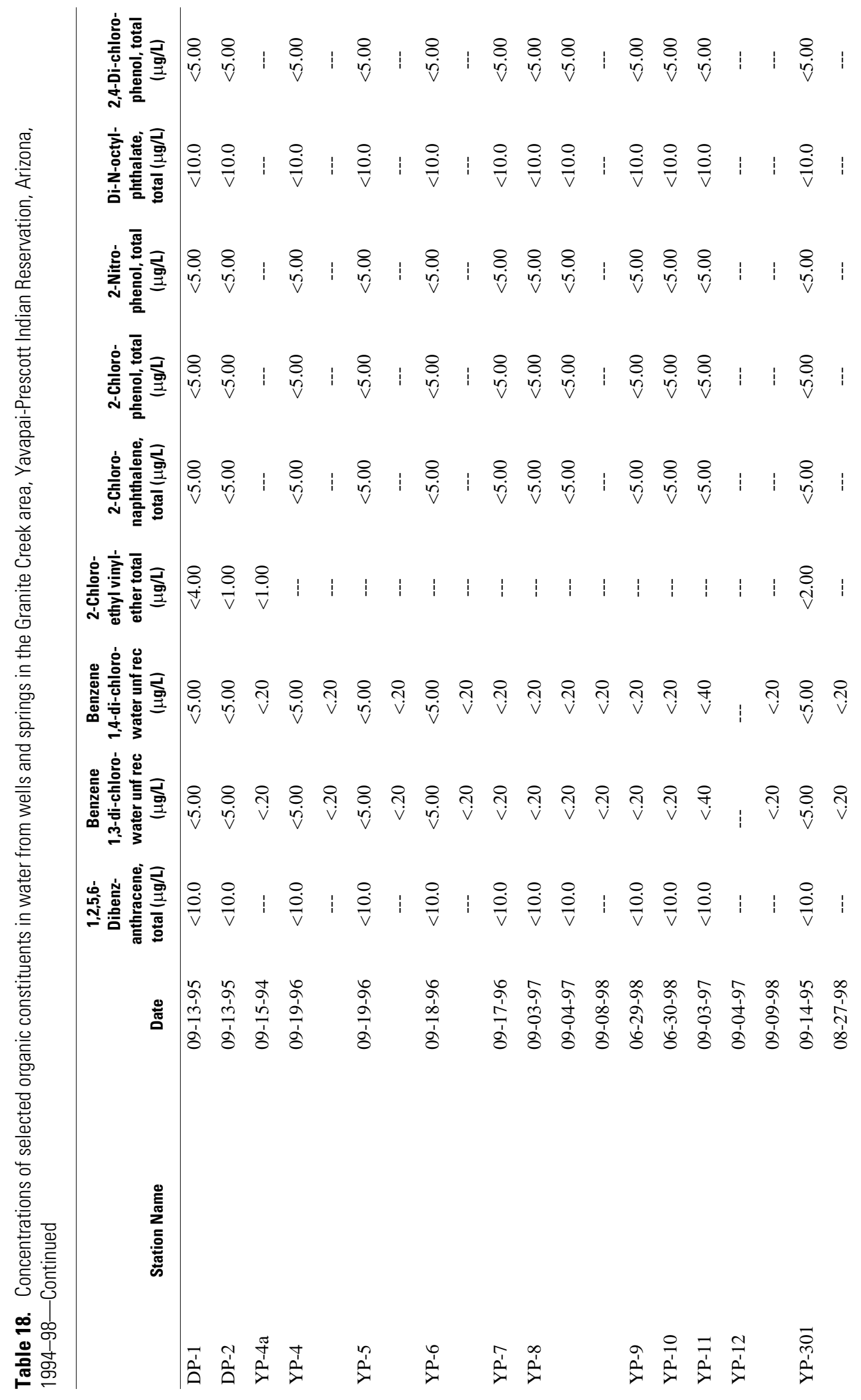

86 Occurrence and Quality of Surface Water and Ground Water within the Yapavai-Prescott Indian Reservation 


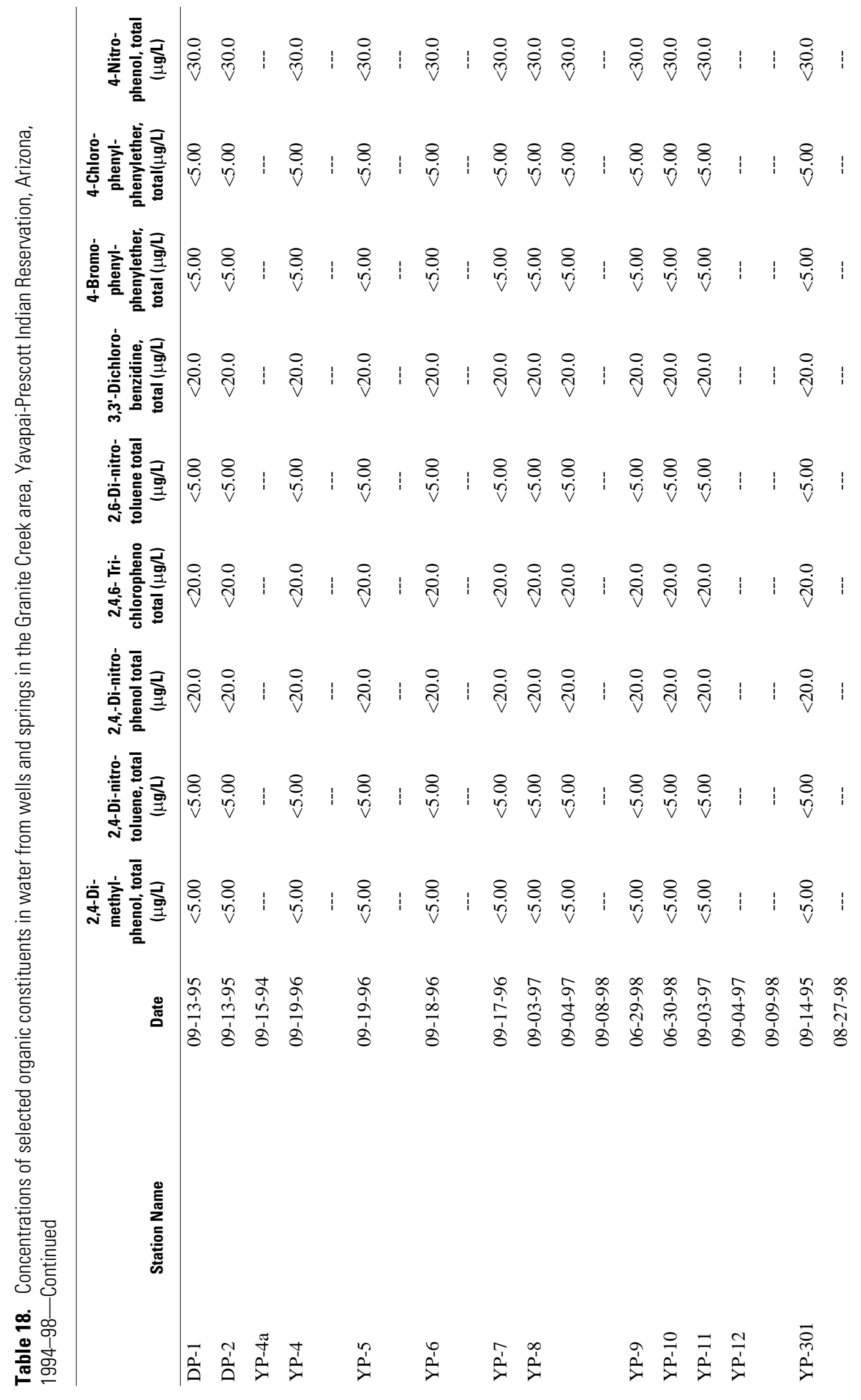




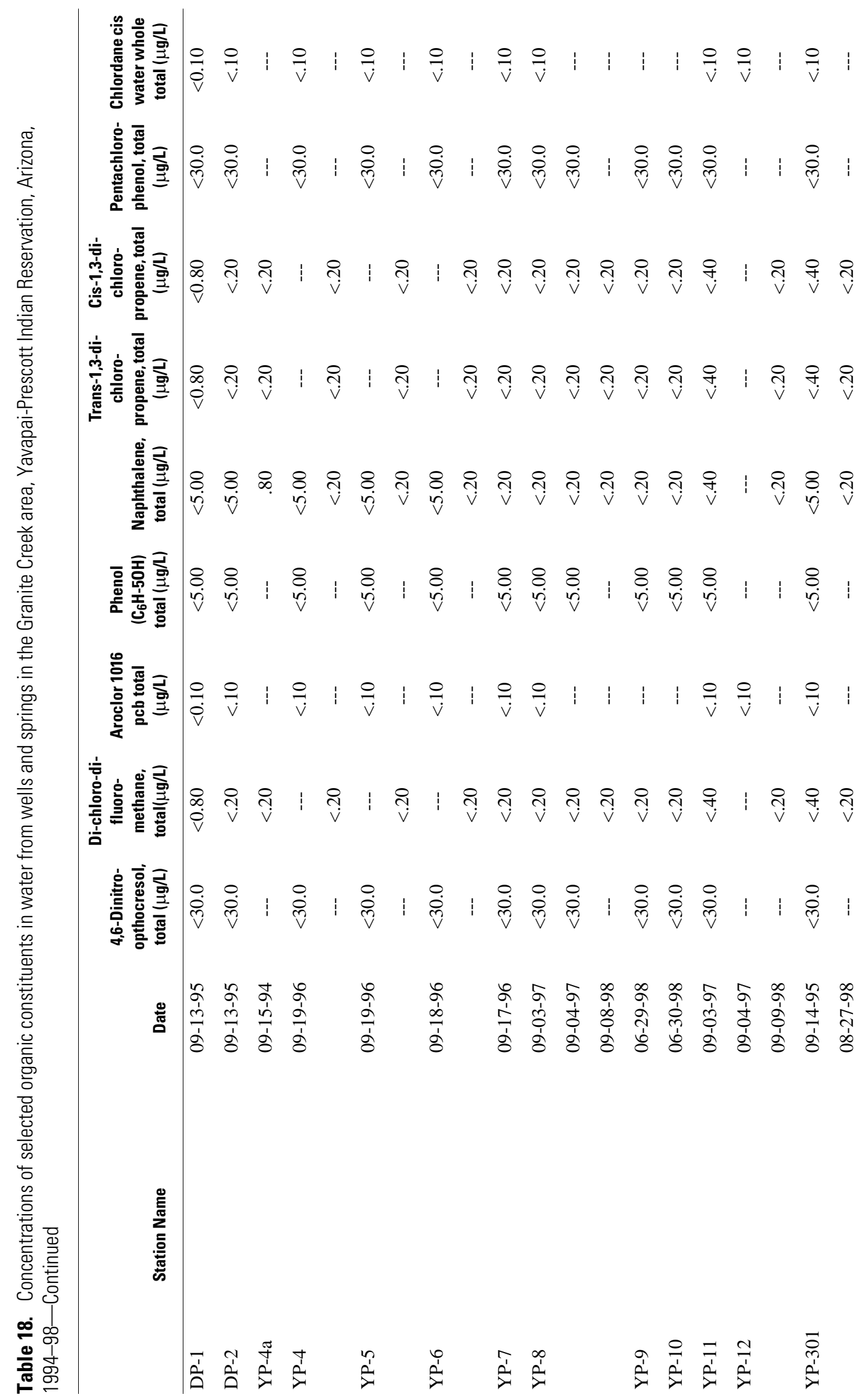

88 Occurrence and Quality of Surface Water and Ground Water within the Yapavai-Prescott Indian Reservation 


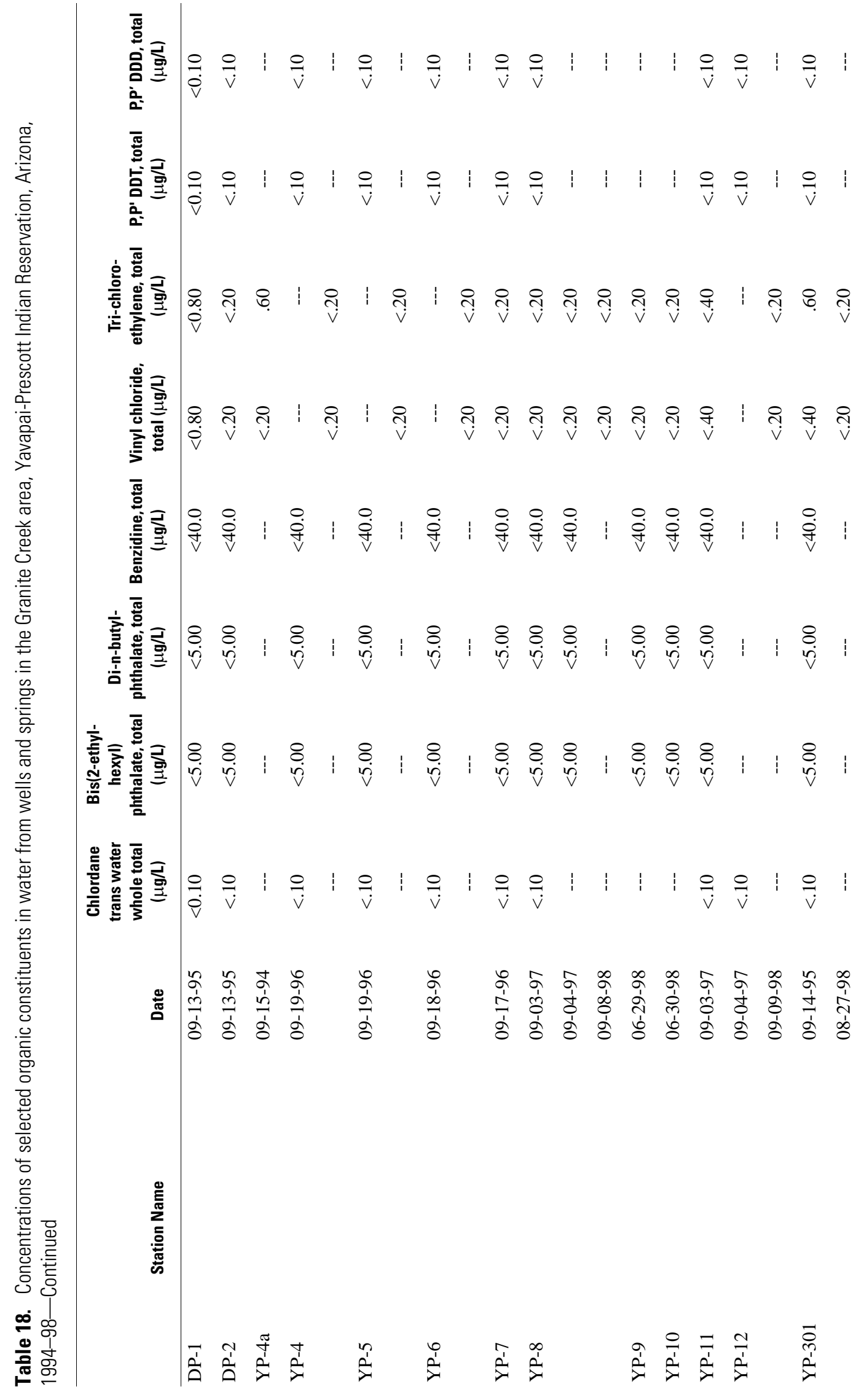




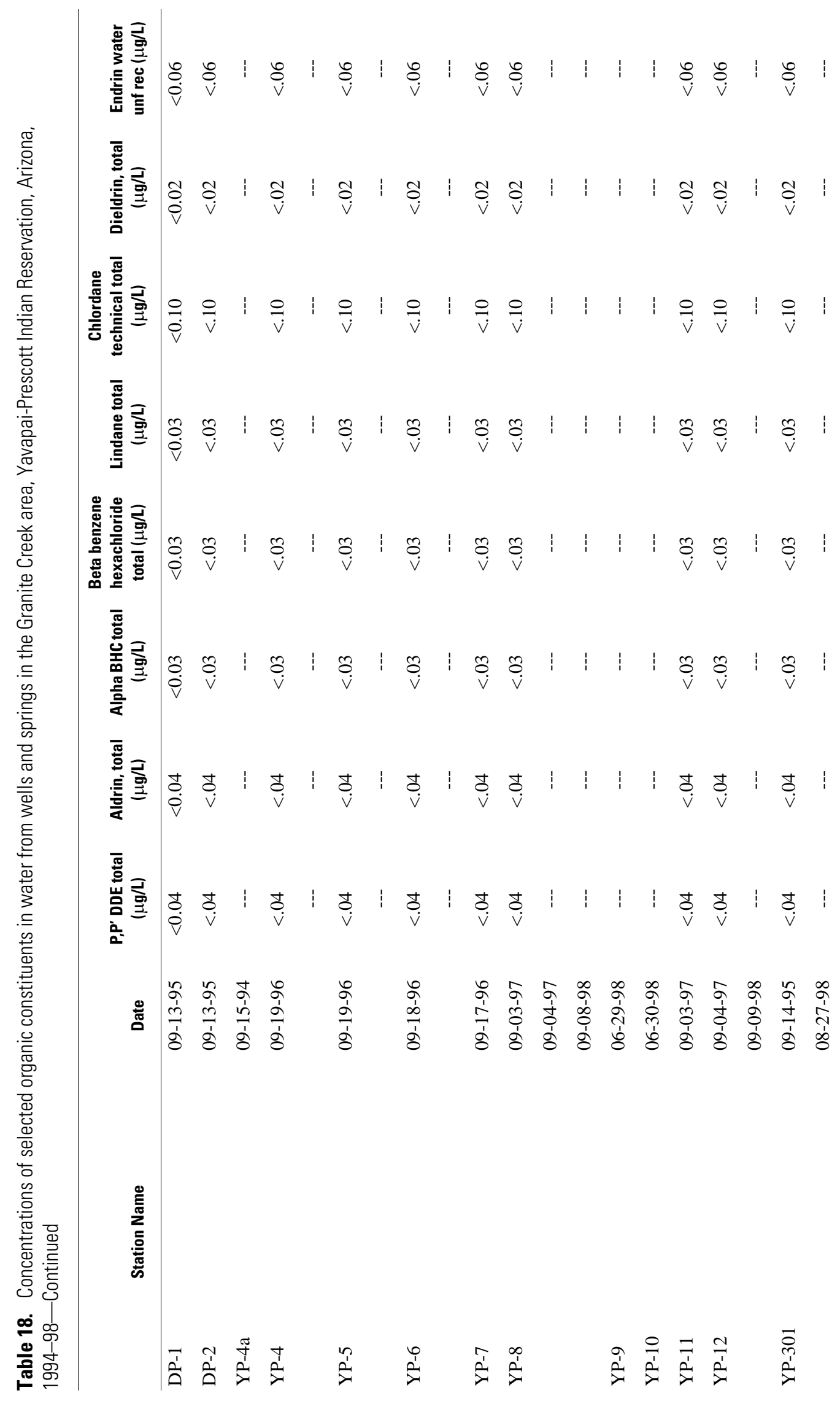

90 Occurrence and Quality of Surface Water and Ground Water within the Yapavai-Prescott Indian Reservation 


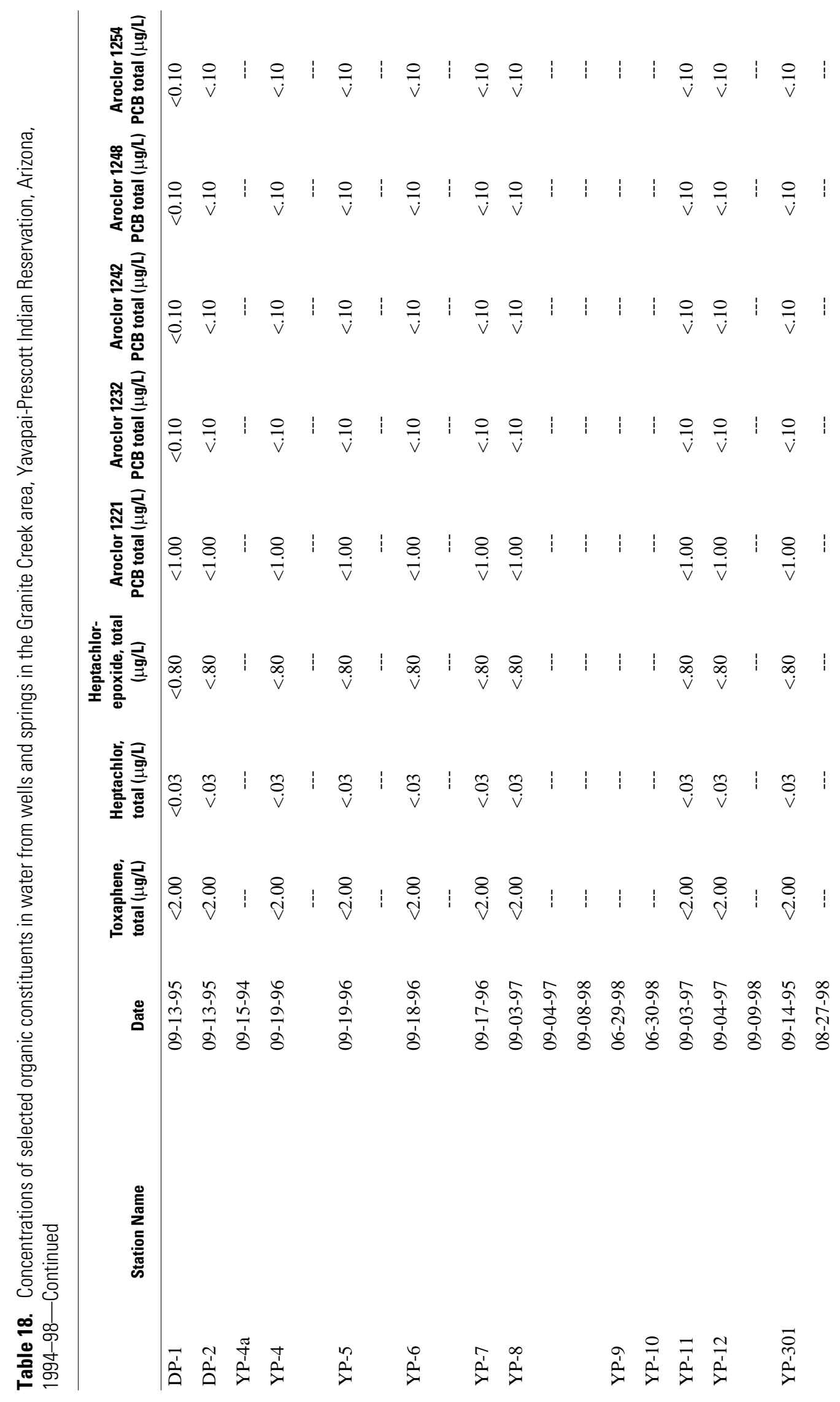




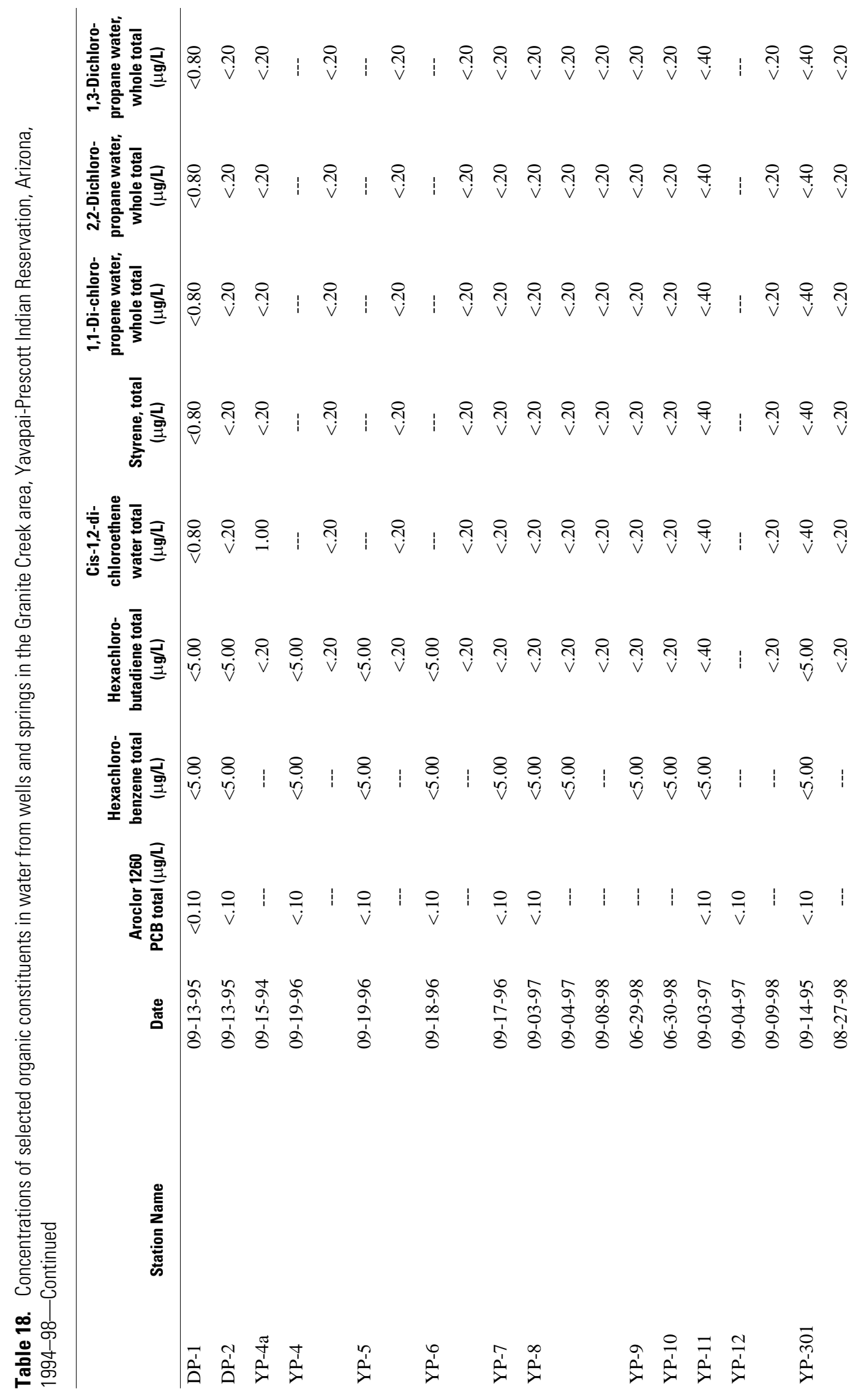

92 Occurrence and Quality of Surface Water and Ground Water within the Yapavai-Prescott Indian Reservation 


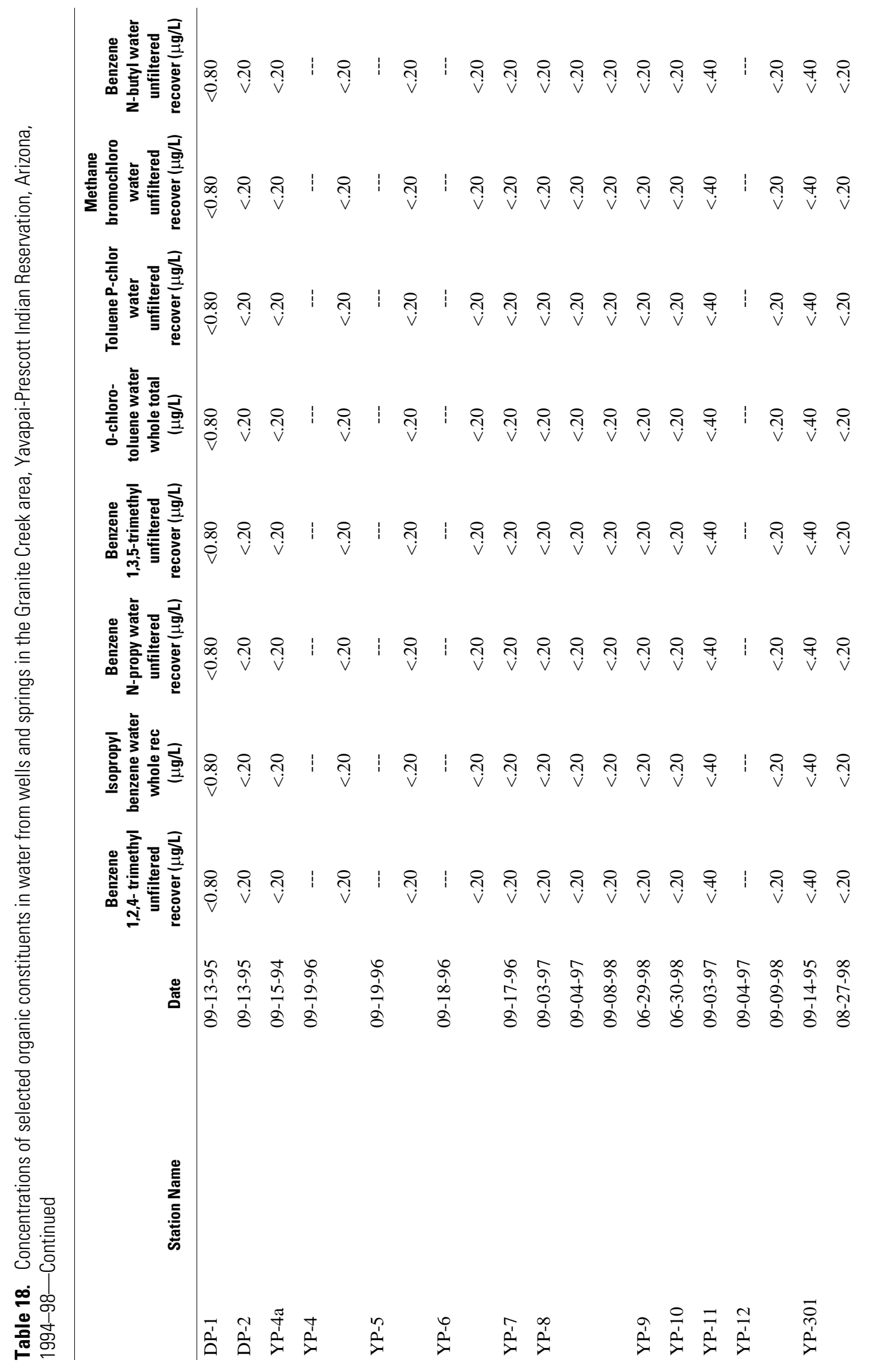




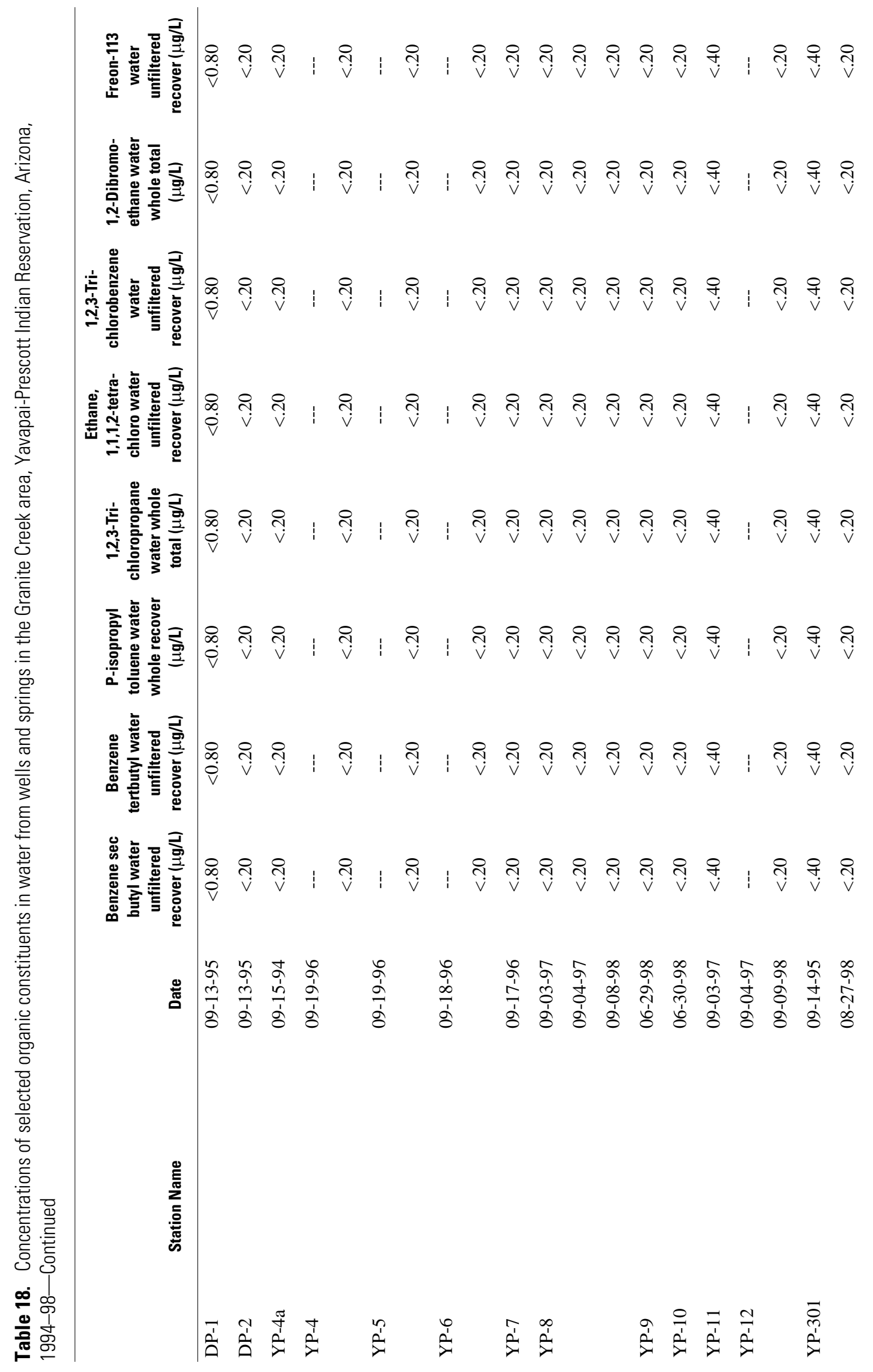

94 Occurrence and Quality of Surface Water and Ground Water within the Yapavai-Prescott Indian Reservation 


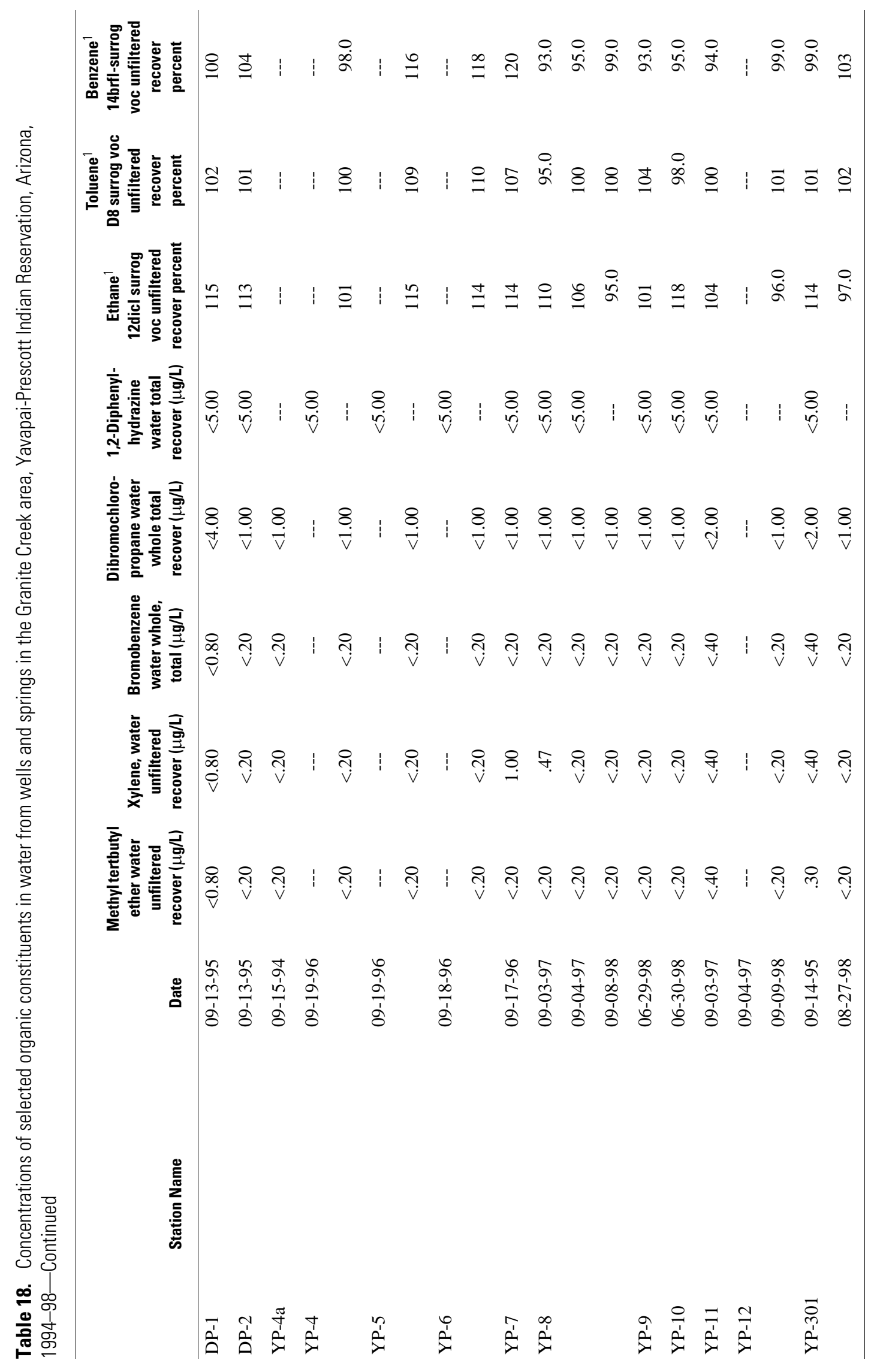

